Universidade de São Paulo Instituto de Psicologia

PAULA HIROMI ITO

AVALIAÇÃO COMPORTAMENTAL DE RATOS SUBMETIDOS À ANÓXIA NEONATAL

São Paulo

2010 
PAULA HIROMI ITO

\section{AVALIAÇÃO COMPORTAMENTAL DE RATOS SUBMETIDOS À ANÓXIA NEONATAL}

Dissertação apresentada ao Instituto de Psicologia da Universidade de São Paulo para defesa de Mestrado em Psicologia área de concentração Neurociências e Comportamento.

Orientador (a): Maria Inês Nogueira, Prof. Dr.

Colaborador:

Gilberto Fernando Xavier, Prof. Dr. 


\section{AGRADECIMENTOS}

A Profa. Maria Inês Nogueira, por todas as oportunidades de aprendizagem, e acima de tudo pelo exemplo de respeito ao próximo.

Ao Prof. Gilberto Fernando Xavier, por ter disponibilizado o seu laboratório e todo o material necessário para que o trabalho pudesse ser realizado e pela disponibilidade com que sempre me atendeu.

Às Professoras, Maria Elisa Pimentel Piemonte e Regina Watanabe Endo, por terem constituído a banca do exame de qualificação e pela relevância das apreciações emitidas.

Ao Instituto de Psicologia da Universidade de São Paulo, pela oportunidade da realização deste trabalho.

Aos funcionários do Biotério Renivaldo (ICB III) e Manoel (Departamento de Fisiologia) pelo carinho, por estarem sempre prontos a me auxiliar, pelo profissionalismo e competência nos serviços prestados.

À Rosana, do serviço de Estatística.

Aos companheiros do laboratório de Neurociências: Vanderlei, Wilma, Silvia, Rômulo, Barbara, Leila, Renné, Roberto, Luciana, Cleyton, Regina, Carmen, Margareth, Jasmim, Renata Vasconcelos, Renata Frazão, Luciano, Eduardo, Paola, Cristiano e Mike pelo carinho e agradável convívio.

À Silvia Takada, pelo impulso inicial e pela paciência em me acompanhar nos primeiros procedimentos.

Ao João Gimenez, por ter me ensinado a utilizar todos os equipamentos, e me ajudado de maneira atenciosa em todos os momentos. 
Agradeço de forma especial aos meus pais Paulo e Shizuka, minhas irmãs Cristina, Priscila e Vanessa, minha sobrinha Letícia e minha tia Toshie, pelo amor incondicional, apoio constante, e por me manterem sempre firme frente aos obstáculos.

Ao meu namorado Vanderlei, exemplo de dedicação e perseverança, pelo companheirismo, por me ajudar em todas as etapas do trabalho e por sempre me motivar a ir em busca dos meus sonhos.

A minha grande amiga Wilma Allemandi, exemplo de amor à vida e respeito ao próximo, por tornar os dias mais suaves e alegres.

À AACD e à Dra. Ana Beatriz Proença, Diretora Clínica da AACD Mooca, pela oportunidade de poder desenvolver trabalho tão especial e prazeroso com as crianças.

Aos colegas de trabalho da AACD, pelo carinho, convívio diário, possibilidade de troca e pelo incentivo constante.

À Oxilúmen, pelo empréstimo do cilindro de Nitrogênio gasoso. 


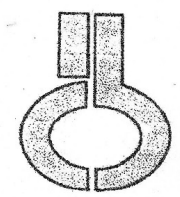

\section{Certificado}

Certificamos que o protocolo registrado sob $\mathrm{n}^{\circ} 134$ nas fls. 38 do livro 2 para uso de animais em experimentação, sob a responsabilidade de Maria Inès Nogueira, Coordenador(a) da Linha de pesquisa "Efeitos da anóxia neonatal no encéfalo de ratos: alteraçōes morfológicas, expressâo da proteína Fos e sua inter relação com o sistema serotoninérgico" do qual participou(aram) o(s) alunos Silvia Honda Takada, Paula Hiromi Ito, Renata Gonçalves de Vasconcellos, está de acordo com os Principios Éticos de Experimentaçäo Animal adotado pelo Colégio Brasileiro de Experimentação Animal (COBEA) e foi aprovado pela COMISSÄO DE ÉTHCA EM EXPERIMENTAÇÄO ANIMAL (CEEA) em 21.11.2006.

São Paulo, 22 de novembro de 2006.

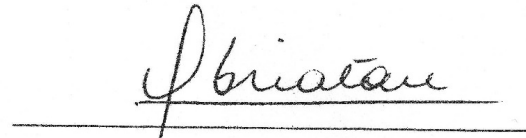

Prof. Dr. UBIRATAN FABRES MACHADO Coordenador da CEEA - ICB/USP

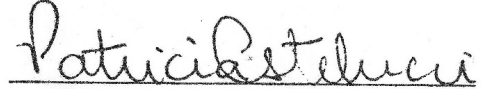

Profa. Dra. PATRICIA CASTELUCCI Secretária da CEEA - ICB/USP 


\section{RESUMO}

ITO, P. H. Avaliação comportamental de ratos submetidos à anóxia neonatal. Dissertação (Mestrado em Neurociências e Comportamento) - Instituto de Psicologia, Universidade de São Paulo, 2009.

A anóxia neonatal é uma das causas mais importantes de lesão encefálica em neonatos. Várias espécies de mamíferos têm contribuído no estudo dos mecanismos patogênicos envolvidos no prejuízo da anóxia/hipóxia, em particular roedores tem sido utilizado com sucesso como modelo da anóxia em humanos. Fatores como a maturidade do encéfalo no momento da deficiência de oxigênio, a duração da asfixia, vulnerabilidade regional e celular específica, apresentam grande influência no surgimento de problemas neurológicos, déficit sensoriomotor, prejuízo no aprendizado e memória. Alterações em processos atentivos e ansiedade também podem afetar as funções cognitivas. Em roedores, tem-se observado marcada hiperatividade na idade infantil, acompanhada por significativa hipoatividade na idade adulta. Os objetivos deste estudo foram avaliar as possíveis alterações comportamentais, tais como memória de referência espacial, memória operacional, alterações sensoriais, ansiedade e aquisição do medo condicionado ao som e ao contexto, em ratos, submetidos à anóxia neonatal. Foram utilizados 25 ratos albinos (Rattus norvegicus, linhagem Wistar) machos, neonatos, divididos em dois grupos experimentais: Anóxia $(n=13)$ e Controle $(n=$ 12). Nos testes envolvendo a memória de referência espacial e memória operacional, o grupo experimental evidenciou que a anóxia neonatal causa prejuízo na capacidade de aprendizagem e navegação espacial no labirinto aquático de Morris, porém verificou-se que ambos os grupos conseguiram valer-se das suas experiências prévias para melhorarem seu desempenho na medida em que passavam pelos diferentes testes (memória de referência espacial, memória operacional com intervalo entre as tentativas de 10, 30 e 0) demonstrados por meio da diminuição na latência e no comprimento do trajeto, sendo esta melhora no desempenho inferior nos animais anóxia. Os animais anóxia, também necessitaram de mais dias de testes, para atingirem desempenho próximo ao encontrado nos animais do outro grupo. Observou-se variação na velocidade do nado ao longo dos dias de testes em ambos os grupos, porém verificou-se que os animais anóxia demonstraram velocidade inferior aos animais controle. No teste do labirinto em cruz elevado os animais anóxia mostraram-se menos ansiosos, tendo permanecido menor tempo em congelamento no teste do medo condicionado ao contexto, porém não ao som. Portanto, estes dados indicam que o modelo de anóxia neonatal utilizado promove alterações neuronais que modificam o comportamento do animal na vida adulta, verificados por meio das alterações comportamentais. Espera-se, com estes resultados, favorecer a compreensão das alterações comportamentais após anóxia neonatal e se possível, abrir caminho para novas abordagens e perspectivas terapêuticas.

Palavras-chave: Anóxia, ratos, memória, ansiedade e medo. 


\section{ABSTRACT}

ITO, P. H. Behavioral assessment of rats subjected to neonatal anoxia. Master Dissertation (Masters in neurociencias and behavior) - Institute of Psychology, University of São Paulo, 2010.

Neonatal anoxia is a major cause of brain injury in newborns. Several species of mammals have contributed to the study of pathogenic mechanisms involved in the injury caused by anoxia / hypoxia; particularly rodents have been used successfully as a model for the study of anoxia in humans. Factors such as maturity of the brain when oxygen deficiency, the duration of asphyxia, specific regional and cell vulnerability, have great influence on the rise of neurological disorders, sensory motor deficit, and impaired learning and memory. Changes in attentional processes and anxiety can also affect cognitive functions. In rodents, there has been marked hyperactivity at young age, accompanied by a significant hypoactivity in adult life. The objectives of this study were to evaluate the possible behavioral changes, such as spatial reference memory, working memory, sensory disturbance, anxiety and acquisition of conditioned fear to the sound and context in rats subjected to neonatal anoxia.

We used 25 albino rats (Rattus norvegicus, Wistar) male neonates, divided into two groups: Anoxia $(n=13)$ and control $(n=12)$. In tests involving spatial reference memory and working memory, the experimental group showed that neonatal hypoxia adversely affects the ability of spatial learning and navigation in the Morris water maze, but it was found that both groups were able to draw on their experiences prior to improve its performance as they passed through various tests (spatial reference memory, working memory at an interval timing between attempts of 10, 30 and 0 ) shown by the decrease in latency and path length, and this improvement in underperform on anoxic animals. Anoxic animals also required more days of testing to achieve performance close to that found in animals of the other group. There was variation in the speed of swimming during the days of testing in both groups, but it was found that the anoxic animals showed lower speed than the control animals. In the elevated plus-maze test, the anoxic animals were less anxious and reminded less time freezing in the conditioned fear test to the context but not to the sound. Therefore, these data indicate that the used neonatal anoxia model promotes neuronal alterations that modify the behavior of the animal in adult life, verified through behavioral changes. It is expected, with these results, to promote understanding of the behavioral alterations after neonatal anoxia and, if possible, to make way for new approaches and therapeutic perspectives.

Keywords: Anoxia, rats, memory, anxiety, fear 
Figura 1. Sistema utilizado para provocar anóxia nos ratos neonatos. Câmara semi-hermética acoplada a cilindro de gás nitrogênio $100 \%$, parcialmente imersa em água aquecida.

Figura 2. Representação esquemática do Labirinto aquático de Morris (Adaptado de Bear, 2002).

Figura 3. Fotografia do labirinto em cruz elevado utilizado para avaliar o nível de ansiedade.

Figura 4. Fotografia do aparelho utilizado no treino da tarefa de condicionamento clássico aversivo e no teste de medo condicionado ao contexto (A) Parte externa do aparelho. (B) Vista superior do aparelho.

Figura 5. Fotografia do aparelho utilizado no teste e medo condicionado ao som. (A) Parte externa do aparelho. (B) Vista superior do aparelho.

Figura 6. Latência dos animais dos grupos controle $(n=12)$ e anóxia $(n=13)$ ao longo dos dias de treinamento no teste de memória de referência espacial no labirinto aquático de Morris. Os valores indicam a Média ( \pm E.P.M.) de 4 tentativas a cada dia.

Figura 7. Latência dos animais dos grupos anóxia $(n=13)$ e controle $(n=12)$ ao longo dos seis dias de treinamento no teste de memória operacional ITI 10 no labirinto aquático de Morris. Os valores indicam a Média ( \pm E.P.M.) das tentativas dos grupos anóxia e controle ao longo dos dias. 56

Figura 8. Latência dos animais dos grupos anóxia $(n=13)$ e controle $(n=12)$ ao longo dos quatro dias de treinamento no teste de memória operacional ITI 30 no labirinto aquático de Morris. Os valores indicam a Média ( \pm E.P.M.) das tentativas dos grupos anóxia e controle ao longo dos dias.

Figura 9. Latência dos animais dos grupos anóxia $(n=13)$ e controle $(n=12)$ ao longo dos quatro dias de treinamento no teste de memória operacional ITI 0 no labirinto aquático de Morris. Os valores indicam a Média ( \pm E.P.M.) das tentativas dos grupos anóxia e controle ao longo dos dias.

Figura 10. Comprimento do trajeto dos animais dos grupos anóxia $(n=13)$ e controle $(n=12)$ ao longo dos seis dias de treinamento no teste de memória operacional ITI 10 no labirinto aquático de Morris. Os valores indicam a Média $( \pm$ E.P.M.) das tentativas dos grupos anóxia e controle ao longo dos dias. .58 
Figura 11. Comprimento do trajeto dos animais dos grupos anóxia $(n=13)$ e controle $(n=12)$ ao longo dos quatro dias de treinamento no teste de memória operacional ITI 30 no labirinto aquático de Morris. Os valores indicam a Média ( \pm E.P.M.) das tentativas dos grupos anóxia e controle ao longo dos dias. .58

Figura 12. Comprimento do trajeto dos animais dos grupos anóxia $(n=13)$ e controle $(n=12)$ ao longo dos quatro dias de treinamento no teste de memória operacional ITI 0 no labirinto aquático de Morris. Os valores indicam a Média $( \pm$ E.P.M.) das tentativas dos grupos anóxia e controle ao longo dos dias. .58

Figura 13. Velocidade do nado dos animais dos grupos anóxia $(n=13)$ e controle $(n=12)$ ao longo dos seis dias de treinamento no teste de memória operacional ITI 10 no labirinto aquático de Morris. Os valores indicam a Média ( \pm E.P.M.) das tentativas dos grupos anóxia e controle ao longo dos dias.

Figura 14. Velocidade do nado dos animais dos grupos anóxia $(n=13)$ e controle $(n=12)$ ao longo dos quatro dias de treinamento no teste de memória operacional ITI 30 no labirinto aquático de Morris. Os valores indicam a Média ( \pm E.P.M.) das tentativas dos grupos anóxia e controle ao longo dos dias. .60

Figura 15. Velocidade do nado dos animais dos grupos anóxia $(n=13)$ e controle $(n=12)$ ao longo dos quatro dias de treinamento no teste de memória operacional ITI 0 no labirinto aquático de Morris. Os valores indicam a Média ( \pm E.P.M.) das tentativas dos grupos anóxia e controle ao longo dos dias. .60

Figura 16. Latências dos animais dos grupos anóxia $(n=13)$ e controle $(n=12)$ ao longo dos três dias de teste com plataforma visível no labirinto aquático de Morris. Os valores indicam a Média ( \pm E.P.M.) das tentativas dos grupos anóxia e controle ao longo dos dias.

Figura 17. Comprimento do trajeto dos grupos anóxia $(n=13)$ e controle $(n=12)$ ao longo dos três dias de teste com plataforma visível no labirinto aquático de Morris. Os valores indicam a Média ( \pm E.P.M.) das tentativas dos grupos anóxia e controle ao longo dos dias. 62

Figura 18. Velocidade do nado dos grupos anóxia $(n=13)$ e controle $(n=12)$ ao longo dos três dias de teste com plataforma visível no labirinto aquático de Morris. Os valores indicam a Média ( \pm E.P.M.) das tentativas dos grupos anóxia e controle ao longo dos dias.

Figura 19. Porcentagem de entrada nos braços abertos dos grupos anóxia $(n=13)$ e controle $(n=12)$ na primeira e segunda sessão de teste no labirinto aquático de Morris. Os valores indicam a Média ( \pm E.P.M.) das tentativas dos grupos anóxia e controle ao longo dos dias. 
Figura 20. Porcentagem de tempo nos braços abertos dos grupos anóxia $(n=13)$ e controle $(n=12)$ na primeira e segunda sessão de teste no labirinto aquático de Morris. Os valores indicam a Média ( \pm E.P.M.) dos grupos anóxia e controle das tentativas ao longo dos dias.

Figura 21. Número de entrada nos braços fechados dos grupos anóxia $(n=13)$ e controle $(n=12)$ na primeira e segunda sessão de teste no labirinto aquático de Morris. Os valores indicam a Média ( \pm E.P.M.) dos grupos anóxia e controle das tentativas ao longo dos dias.

Figura 22. Tempo de permanência no quadrado central dos grupos anóxia $(n=13)$ e controle $(n=12)$ na primeira e segunda sessão de teste no labirinto aquático de Morris. Os valores indicam a Média ( \pm E.P.M.) dos grupos anóxia e controle das tentativas ao longo dos dias.

Figura 23. Número de cruzamento no quadrado central dos grupos anóxia $(n=13)$ e controle $(n=12)$ na primeira e segunda sessão de teste no labirinto aquático de Morris. Os valores indicam a Média ( \pm E.P.M.) dos grupos anóxia e controle das tentativas ao longo dos dias.

Figura 24. Porcentagem do tempo total em congelamento (média \pm erro padrão) durante o teste de medo condicionado ao contexto.

Figura 25. Porcentagem do tempo total em congelamento (média \pm erro padrão) durante o teste de medo condicionado ao contexto.

Figura 26. Porcentagem do tempo total em congelamento (média \pm erro padrão) durante o teste de medo condicionado ao som.

Figura 27. Porcentagem do tempo total em congelamento (média \pm erro padrão) durante o teste de medo condicionado ao som. 
ABREVIATURAS E SIGLAS

\begin{tabular}{|l|l|}
\hline $\mathbf{I T I}$ & Intervalo entre as tentativas \\
\hline $\mathbf{p H}$ & Potencial Hidrogeniônico \\
\hline $\mathbf{p O} \mathrm{O}_{2}$ & Pressão parcial de oxigênio \\
\hline TDAH & Transtorno de déficit de atenção e hiperatividade \\
\hline
\end{tabular}


1.0 INTRODUÇÃO

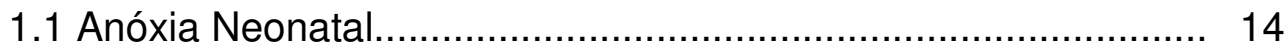

1.2 Memória Espacial.............................................................. 14

1.3 Ansiedade e Medo................................................................ 22

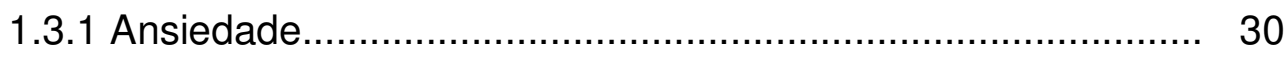

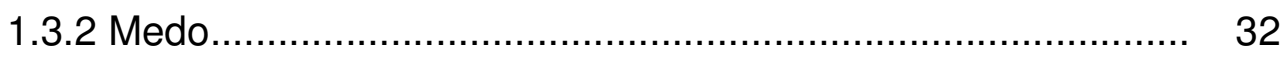

2.0 OBJETIVOS.

2.1 Objetivos Específicos......................................................... 38

3.0 MATERIAIS E MÉTODOS......................................................... 38

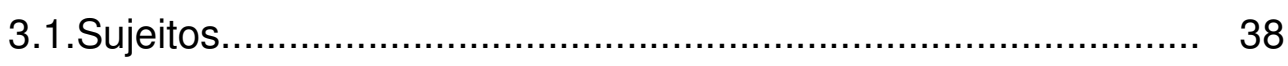

3.2 Condição Experimental........................................................ 39

3.3 Testes Comportamentais..................................................... 41

3.3.1 Labirinto aquático de Morris.............................................. 41

3.3.2 Labirinto em cruz elevado................................................. 45

3.3.3 Treino de condicionamento clássico aversivo........................ 47

3.3.4 Teste de medo condicionado ao contexto................................. 49

3.3.5 Teste de medo condicionado ao som................................... 49

4.0 ANÁLISE ESTATÍSTICA.......................................................... 51

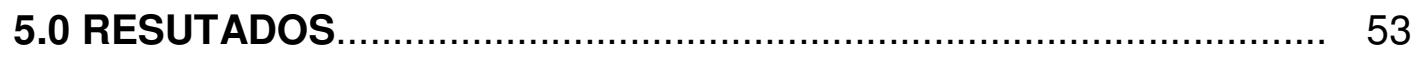

5.1 Memória de referência espacial............................................. 54

5.2 Memória operacional.......................................................... 55

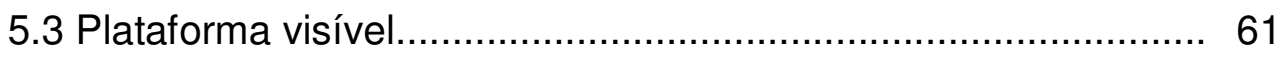

5.4 Labirinto em cruz elevado..................................................... 64

5.5 Teste de medo condicionado ao contexto e ao som.................... 69

6.0 DISCUSSÃO

6.1 Labirinto aquático de Morris.................................................... 73

6.2 Labirinto em cruz elevado....................................................... 78

6.3 Teste de medo condicionado ao contexto e ao som.................. 79 
7.0 CONCLUSÂO.

83

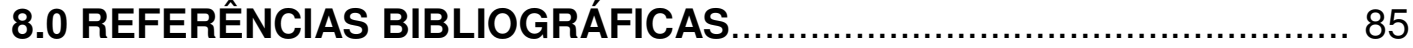




\subsection{INTRODUÇÃO}

\subsection{ANÓXIA NEONATAL}

A anóxia neonatal e mesmo a hipóxia desperta interesse científico, uma vez que é uma das causas mais importantes de danos cerebrais nos recém nascidos, que freqüentemente tem como resultado um risco maior de provocar danos que prejudicam o desempenho com relação ao aprendizado e a memória, persistindo por toda a vida do indivíduo afetado (Mikati et al., 2005; Hen et al., 2007).

A anóxia corresponde à falta de oxigênio à tentativa de respiração, é a condição onde a concentração de oxigênio ambiente é praticamente zero. Observa-se que, o termo anóxia é muitas vezes também utilizado, para descrever a hipóxia.

A hipóxia é a redução do suprimento de oxigênio nos tecidos orgânicos. A hipóxia aguda cerebral no recém-nascido, decorrente de condições patológicas maternas, obstétricas e/ou do próprio concepto, ocorre mais freqüentemente no contexto do fenômeno isquêmico determinado por hipofluxo cerebral (Lou et al., 1997). A hipóxia isolada, sem isquemia é mais rara, ocorrendo, por exemplo, na síndrome de aspiração de mecônio (Madi et al., 2003), a que está mais sujeito o recém nascido pós-termo (McMahon et al., 1996) ou por refluxo gastro-esofágico após cesariana (Zhao et al., 1996) que pode ocorrer por diversos fatores, como obstrução física do fluxo sangüíneo em qualquer nível da circulação corpórea ou deslocamento para áreas com concentrações baixas de oxigênio no ar. A privação de oxigênio pode decorrer da asfixia, estado em que as trocas gasosas placentárias ou pulmonares são interrompidas, causando progressiva hipoxemia, que pode evoluir até estar associada à acidose, que pode ser respiratória, metabólica ou fisiológica. A acidose respiratória é decorrente de troca gasosa pulmonar ou placentária deficitária, enquanto que a metabólica ocorre devido ao acúmulo de ácido lático na corrente sanguínea e tecidos, em conseqüência da glicólise anaeróbica. Tipicamente, a asfixia está associada com um misto de acidoses metabólica e respiratória (Nyakas et al., 1996). 
O processo do nascimento por si só está associado com uma leve asfixia fisiológica: todos os neonatos apresentam redução na pressão parcial de oxigênio (pO2) e pH durante o parto, característicos da asfixia. Esta asfixia fisiológica do nascimento não causa danos aos tecidos, a menos que fatores aumentem a predisposição do neonato a lesões decorrentes da privação temporária de oxigênio (Gluckman et al., 2001). Por esta razão, eventos relacionados ao nascimento que podem causar danos ao encéfalo em desenvolvimento (estrutura mais susceptível no neonato), são considerados potencialmente perigosos para o bebê (Johnston et al., 2002). Mais freqüentemente, as complicações estão relacionadas à anóxia, hipóxia, isquemia ou a combinação entre elas (Bohr, 2004). Atualmente, existe forte evidência de que a lesão encefálica ocorre comumente no período perinatal que começa em 22 semanas completas (154 dias) de gestação (época em que o peso de nascimento é normalmente de $500 \mathrm{~g}$ ) e termina com 7 dias completos após o nascimento (considerada por alguns autores como período neonatal, que começa no nascimento e termina com 28 dias completos depois do nascimento), podendo ser potencialmente tratável (Gunn e Bennet, 2008).

A hipóxia/anóxia é considerada um dos mais sérios problemas em países menos desenvolvidos, onde cuidados e precauções não estão sempre disponíveis ou são aplicados adequadamente (Costello et al., 1994). Nestes países, as crianças portadoras de paralisia cerebral associada ou não a outras seqüelas decorrentes de privação de oxigênio neonatal, por exemplo, correspondem a quase $70 \%$ dos pacientes atendidos em centros de reabilitação pediátrica.

Estatísticas sugerem incidência de asfixia neonatal em 2-4/1000 crianças nascidas a termo, mas um nível de incidência bastante alto, aproximadamente $60 \%$, em neonatos prematuros com baixo peso, constituindo grande preocupação para a saúde pública (Vannucci, 1997; Laviola et al., 2004). A ocorrência de anóxia em recém nascidos pré-termo (que corresponde a menos de 37 semanas completas - menos de 259 dias - de gestação) está relacionada, em parte, à vulnerabilidade do cérebro imaturo ao ambiente extra-uterino. Entretanto, fatores antenatais podem estar envolvidos levando à agressão hipóxia ou isquêmica, ainda antes do nascimento. Cerca de $20 \%$ a $50 \%$ dos bebês asfixiados que 
apresentam seqüelas falecem durante os primeiros meses de vida (Vannucci, 1997), sendo a freqüência maior na primeira ou segunda semana (Who, 2003), entretanto, estudos mostraram que estas taxas estão desatualizadas (WilsonCostello et al., 2005). Com os avanços tecnológicos, novos conhecimentos e estratégias terapêuticas, neonatos prematuros têm maiores taxas de sobrevivência quando comparadas com períodos anteriores (Suguihara et al., 2005).

Entre os fatores de risco para a hipóxia ou anóxia pré, peri ou pós-natais citam-se a falta de cuidados pré-natais, estado nutricional materno deficiente, hemorragia pré-natal, toxemia materna (Majeed et al., 2007), infecções do neonato, más formações congênitas, baixo peso ao nascimento, apresentação fetal anômala, parto prolongado e difícil, septicemia, hiperbilirrubinemia, meningoencefalites bacterianas ou virais, complicações obstétricas e mecânicas, pós-maturidade e prematuridade (Baladi et al., 2007).

Dentre os importantes fatores de risco para a hipóxia/anóxia ao nascimento, encontra-se a prematuridade (Gluckman et al., 2001). Os pulmões dos neonatos prematuros extremos (24 - 26 semanas) estão em estágio de desenvolvimento diferente dos pulmões dos nascidos a termo. Neste estágio, o pulmão está apenas começando a ser viável para trocas gasosas. Deste modo, o parto prematuro e o início da respiração interrompem o desenvolvimento normal dos alvéolos e da vascularização pulmonar destas crianças. Os pulmões de prematuros ainda são geralmente deficientes em surfactantes, tornando-os mais predispostos a complicações respiratórias (Suguihara et al., 2005).

Estudos demonstram que apesar do sistema nervoso central imaturo apresentar maior tolerância a eventos hipóxicos (Volpe, 1992; Dell'Anna et al., 1993; Nakajima et al., 1996; Nakajima, 1999), há janelas de períodos críticos, onde o encéfalo está mais vulnerável e os neurônios em desenvolvimento estão particularmente mais suscetíveis ao insulto hipóxico ou outras influências ambientais nocivas, que podem influenciar negativamente sua maturação (Nyakas et al., 1996). 
A teoria do período vulnerável foi introduzida por Dobbing (1968), que propôs que o encéfalo está mais vulnerável a insultos nas fases de grande e rápido crescimento celular. $\mathrm{O}$ primeiro período crítico ocorre durante a multiplicação e organização iniciais de neuroblastos que, nos mamíferos, acontece no período pré-natal (Morgane et al., 1993). O segundo período crítico ocorre na fase de aleitamento do rato (Winick e Noble, 1966), quando há rápido crescimento do encéfalo, com migração e diferenciação neuronais, sinaptogênese, multiplicação glial e mielinização evidentes (Dobbing, 1970; Morgane et al., 1993; Manhães de Castro et al., 2001).

A seqüência correta e ordenada da migração celular e a formação de uma microarquitetura apropriada podem definir períodos críticos adicionais, uma vez que, para adequado funcionamento encefálico, é fundamental o crescimento de processos neuronais, como axônios e dendritos, e o estabelecimento adequado de suas interconexões sinápticas ao alvo e células de projeção, respectivamente (Nyakas et al., 1996). A patofisiologia da maioria das desordens comportamentais decorrentes da hipóxia/anóxia neonatal, como o transtorno de déficit de atenção e hiperatividade e distúrbios de memória espacial e aprendizagem, está associada a alterações do funcionamento monoaminérgico central (Raskin et al., 1984; Herlenius e Lagercrantz, 2001).

Neurotransmissores como as monoaminas aparecem no embrião antes dos neurônios estarem diferenciados e podem ter outras funções além da neurotransmissão, como diferenciação e crescimento neuronal. As funções dos sistemas de neurotransmissores no encéfalo em desenvolvimento podem ser alvos do insulto hipóxico ou anóxico, provavelmente ocasionando déficits comportamentais (Nyakas et al., 1996). O oxigênio molecular é o substrato para a ação das enzimas tirosina e triptofanohidroxilase, envolvidas na síntese das catecolaminas (dopamina, norepinefrina e epinefrina) e das indolaminas (serotonina), tornando-as particularmente susceptíveis aos efeitos da hipóxia (Davis et al., 1973).

Entre as monoaminas, está a serotonina que é envolvida na morfogênese precoce do coração, epitélio craniofacial e outras estruturas. Ocorrem 
malformações craniais específicas, caso o embrião se desenvolva em cultura, na presença de inibidores da recaptação de serotonina. As células serotoninérgicas na rafe estão entre as primeiras a serem geradas no encéfalo (entre E11 e E15 no rato e entre a quinta e a décima segunda semanas no feto humano). Estas células enviam axônios ao córtex frontal e podem ter importância na diferenciação de progenitores neurais (Lauder et al., 1994).

Para o desenvolvimento normal do encéfalo, a norepinefrina é essencial. 0 sistema noradrenérgico regula o desenvolvimento das células de Cajal-Retzius, que são os primeiros neurônios a se formarem no córtex (Naqui et al., 1999). A depleção de norepinefrina no período perinatal resulta em alterações dendríticas e possivelmente em alterações da diferenciação cortical (Berger-Sweeny e Hohmann, 1997).

Em especial, a dopamina tem papel fundamental na programação motora e cognitiva. Em humanos, os neurônios dopaminérgicos aparecem precocemente (6 a 8 semanas de desenvolvimento) (Sundstrom et al., 1993). Disfunções no desenvolvimento do sistema dopaminérgico podem ocasionar discinesia, distonia, tiques, transtorno obsessivo-compulsivo e movimentos oculares anormais (Herlenius e Lagercrantz, 2001).

A anóxia exacerba a transmissão de sinais químicos na sinapse, causando não só distúrbios na neurotransmissão como também modulando o posterior desenvolvimento desses neurônios. Estudos mostram que neurônios em desenvolvimento utilizam neurotransmissores para construir não somente conexões funcionais, mas também promover diferenciação morfológica dentro do mesmo circuito funcional. Estas atividades neuronais envolvem interrelação entre eventos celulares e moleculares pré e pós-sinápticos que possuem importante plasticidade. Assim, tanto funções pré como pós-sinápticas podem ser influenciadas e distorcidas como conseqüência de insulto hipóxico (Nyakas et al., 1996), levando a distúrbios comportamentais (Herlenius e Lagercrantz, 2001).

O encéfalo é extremamente sensível a reduções no suprimento de oxigênio; esta vulnerabilidade deve-se a seu alto consumo energético, que não pode ser comprometido (Lutz e Prentice, 2002). 
O organismo reage à privação de oxigênio tentando manter as funções celulares o mais próximo da normalidade possível e posteriormente, quando esgotadas as possibilidades energéticas acabam levando à falência do sistema de proteção, acarretando morte celular.

A privação de oxigênio dispara uma cascata de eventos bioquímicos que ocorrem quase que simultaneamente (Vexler e Ferriero, 2001). Esta cascata envolve: interrupção do metabolismo energético, desequilíbrio ácido-básico, acúmulo de espécies oxigênio-reativas e de aminoácidos excitatórios no espaço extracelular, perda do equilíbrio de água celular e início da apoptose (Engidawork et al., 1997; Vexler e Ferriero, 2001). Estes eventos são rápidos e de curta duração, assim, o espaço de tempo para intervenções terapêuticas é bastante reduzido (Engidawork et al., 1997).

Estas mudanças acarretam em lesão ou morte das células mais vulneráveis do sistema nervoso central, primariamente localizada no hipocampo, especialmente na sub-região CA1 (Buwalda, 1995; Dell'Anna et al., 1991; Hu et al., 1997; Takagi et al.,2000; Jayalakshmi et al.,2007), no córtex cerebral e núcleos basais (mais susceptíveis a lesões no último trimestre de gestação); estas áreas estão envolvidas em funções cognitivas - aprendizado e memória e funções motoras (Loidl et al., 2000; Cirulli, 2003). O hipocampo é conhecido por seu importante papel na memória espacial e é uma das regiões mais sensíveis à anóxia (Schmidt-Kastner e Freund, 1991). A neurotransmissão colinérgica no hipocampo está intimamente envolvida nas funções cognitivas (Spencer et al., 1985) e o desenvolvimento deste sistema transmissor é sensível à anóxia perinatal (Nyakas et al., 1996).

As conseqüências anatômicas da privação de oxigênio nos neurônios em desenvolvimento variam da morte celular à diferenciação prejudicada de extremidades celulares, como dendritos e axônios. Neurônios imaturos que sobrevivem ao insulto hipóxico agudo podem ainda ter comprometimento da formação de sinapses e crescimento de neuritos. Aparentemente estas mínimas anormalidades anatômicas podem ser bases de disfunções comportamentais e psicológicas (Nyakas et al., 1996). 
Em mamíferos, fatores como a maturidade do encéfalo no momento da deficiência de oxigênio, a duração da asfixia, a vulnerabilidade regional e celular específica, dentre outros (Buwalda, 1995; Cirulli, 2003), têm grande influência no aparecimento de problemas neurológicos, como déficit intelectual, epilepsia, prejuízo motor (Buwalda, 1995; Cirulli, 2003) incluindo paralisia cerebral (Johnston, 2002), déficit sensoriomotor (Robertson e Finer, 1993), deficiências auditivas e visuais (Johnston, 2002), distúrbios comportamentais, como prejuízo no aprendizado e memória espacial (Hedner e Lundborg, 1980; Dell'Anna et al., 1995a; Dell'Anna et al., 1997; Wainwright et al., 2004; Casolini et al., 2005; Chen, et al., 2007; Rogalska et al., 2006).

Resultados de vários estudos, em roedores demonstram a existência de relação entre estresse, ansiedade e funcionamento cognitivo. Prejuízo na memória e aprendizagem após anóxia neonatal podem, também ser causados em parte por distúrbios emocionais e ansiedade (Buwalda, 1995). Alterações em processos atentivos, podem também afetar as funções cognitivas (Buwalda 1995). Estes distúrbios tendem a ser permanentes, persistindo por toda a vida (Nyakas et al., 1996).

Vários estudos, em ratos, tem demonstrado uma marcada hiperatividade na idade infantil, (Speiser et al., 1983; Dell'Anna et al., 1991; Volpe, 1992; Buwalda, 1995; Farone e Biederman, 1998; Vannucci et al., 1999; Cannon et al., 2002; Caputa et al., 2005) acompanhada por significativa hipoatividade na idade adulta (Nyakas et al., 1996; Loidl et al., 2000; Venerosi, 2004).

Eventos hipóxicos e anóxicos têm sido relacionados, ainda, à etiologia de uma série de desordens psiquiátricas, incluindo esquizofrenia e autismo (Brixley et al., 1993; Cannon et al., 2002).

Pesquisas demonstraram que os déficits de memória espacial persistem até a vida adulta em ratos após anóxia neonatal, assim como insultos hipóxicos em humanos podem causar prejuízos cognitivos e desordens comportamentais permanentes. $O$ distúrbio de aprendizagem é um dos meios mais sensíveis para se detectar efeitos adversos neuronais da hipóxia no desenvolvimento cerebral (Nyakas et al., 1996). 
Várias espécies de mamíferos têm contribuído no estudo dos mecanismos patogênicos envolvidos no prejuízo da anóxia/hipóxia. Em particular roedores tem sido utilizados com sucesso, como modelo da hipóxia, em humanos (Bjelke et al., 1991, Dell'Anna et al., 1997).

Comparado ao humano, o rato nasce prematuramente, ou seja, o estágio de maturação encefálica do rato neonato é comparável ao final do segundo trimestre em humanos (por volta da vigésima quarta semana de gestação). O nível de maturidade do encéfalo de um rato de dez dias de vida pós-natal se aproxima ao estágio de desenvolvimento de um encéfalo de humano recém nascido a termo (Nyakas et al., 1996).

Diferentes metodologias são utilizadas para provocar privação de oxigênio em ratos antes, durante ou logo após o nascimento, as três metodologias mais utilizadas são: anóxia neonatal, asfixia perinatal e hipóxia-isquemia.

No modelo da anóxia neonatal, neonatos com aproximadamente 30 horas de vida são colocados em câmara contendo $100 \%$ de nitrogênio, durante 20 a 30 minutos (Dell'Anna et al., 1995b; Speiser et al., 1998; Laviola et al., 2004; Rogalska et al., 2004; Tang e Nakazawa, 2005).

$\mathrm{Na}$ asfixia perinatal, a fêmea prestes a dar cria é decapitada ou anestesiada e seu útero contendo os filhotes é retirado, sendo mergulhado em solução salina durante alguns minutos (artigos descrevem de 16 a 25 minutos) (Dell'Anna et al., 1995a; Flores et al., 2002; El-Khodor e Boska, 2003; Cirulli et al., 2003; Juárez et al., 2003; Venerosi et al., 2004). Neste modelo é necessária a eutanásia da mãe dos animais e sua substituição por outra fêmea, o que pode gerar estresse nos filhotes.

Na hipóxia-isquemia, ratos neonatos com 7 dias de vida são submetidos à cirurgia de oclusão de uma das artérias carótidas comuns sendo posteriormente colocados em câmara contendo $8 \%$ de oxigênio e $92 \%$ de nitrogênio, durante período variável - de 30 minutos a 3 horas (Rice et al., 1981; Gunn et al., 1990; Adén et al., 1994; Vannucci et al., 1999; Oorschot et al., 2000; Ten et al., 2003). Neste modelo, permite-se visualizar ação unilateral, quando não realizado 
bilateralmente, acometendo de forma assimétrica o encéfalo do animal. Por este motivo dificulta a análise comportamental destes animais.

Neste estudo, optou-se pelo modelo da anóxia neonatal (que tenta simular o insulto anóxico que acomete o prematuro com cerca de 24 semanas), visto que corresponde a metodologia mais utilizada em pesquisas de seqüelas comportamentais decorrentes da privação de oxigênio. Este método, não é invasivo e possui menos variáveis de estresse. Estudos revelam que o modelo da anóxia neonatal, não induz conseqüências neurológicas maiores, mas é capaz de provocar déficits associados com prejuízo hipocampal (Dell'Anna et al., 1995a) e alterações na maturação do sistema monoaminérgico (Dell’Anna et al., 1993).

\subsection{MEMÓRIA ESPACIAL}

Memória é a capacidade que os animais apresentam para modular seu comportamento de acordo com experiências prévias (Xavier, 1993).

De acordo com este mesmo autor (1989), os animais aprendem a se deslocar no ambiente onde vive de uma forma um tanto flexível, e esta aprendizagem se constitui em elemento fundamental para a sobrevivência das espécies.

Testes de memória espacial vêm sendo realizados em laboratórios, principalmente com labirintos, onde o ambiente é controlado, visto que o estudo da memória espacial de animais em ambientes naturais é relativamente difícil, em função das dificuldades de se controlar os estímulos que influenciam sua orientação. As teorias atuais sobre cognição animal sofreram grande influência de idéias decorrentes da observação de animais desempenhando tarefas em labirintos. Conceitos como memória visuo-espacial, raciocínio na resolução de novas situações, bem como grande parte das concepções sobre aprendizagem e memória, surgiram no contexto da experimentação em labirintos (Oton, 1979).

Recentemente, o desenvolvimento e aperfeiçoamento de novos modelos de labirintos vêm permitindo o direcionamento da pesquisa para aspectos mais 
específicos e sutis das funções cognitivas, tornando a compreensão dessas funções mais precisa e completa. Desta forma, uma diversidade de labirintos surgiu cada qual em função de suas características favorecendo a avaliação de aspectos cognitivos específicos.

Labirintos são amplamente utilizados em estudos de aprendizagem animal. Normalmente, labirintos pressupõem que animais aprendam determinada localização que Ihes ofereça segurança, comida, ou outra situação ou objeto desejado. Essas informações sobre diferentes locais de um labirinto devem ser aprendidas e armazenadas por períodos variáveis de tempo.

Para a investigação da memória espacial em roedores, diferentes tipos de labirintos vêm sendo utilizados. Dentre eles estão o labirinto radial de oito braços (Olton e Samuelson, 1976), o labirinto aquático de Morris (Morris, 1981; Santos, 1999), o labirinto em T (Costa et al., 2005), entre outros. Dentre os diversos procedimentos e aparelhos desenvolvidos para avaliar o desempenho de animais em labirintos, o teste de aprendizagem espacial - no labirinto aquático introduzido na década passada por Richard Morris (1981), vem se destacando nos estudos sobre a neurobiologia da memória (Gallagher et al., 1993). O labirinto aquático é intensamente utilizado em pesquisas sobre as capacidades de orientação espacial em roedores, sobre a retenção dessas informações no sistema nervoso por períodos variáveis de tempo, bem como na investigação dos mecanismos neurais subjacentes a essas capacidades.

A navegação é um processo de determinação e manutenção de um curso ou trajetória de um lugar para outro. É um processo comportamental fundamental para qualquer animal que partindo de um ponto fixo do ambiente retorne a ele. Este local pode ser de significado adaptativo, tais como: fonte de nutrientes, localização do ninho, da colméia, do abrigo, entre outros.

A determinação ou estabelecimento de um curso requer uma representação espacial, uma representação da posição do animal no espaço e a dos locais para os quais o animal dirige seus movimentos, ou seja, são necessárias informações acerca de posições e posicionamentos. A manutenção de um curso requer que estímulos ou sinais ambientais sejam obtidos e analisados pelo animal durante $o$ 
desempenho comportamental de deslocamento direcional.

Nestes labirintos, a navegação pode ser guiada de diferentes maneiras a depender do que se objetiva investigar. O'Keefe e Nadel (1978) distinguiram diversas estratégias utilizadas pelos animais para navegar no ambiente e sugeriram que mais de uma estratégia pode ser utilizada simultaneamente para resolver tarefas espaciais. Esses autores propuseram a teoria do mapa cognitivo, que discute os mecanismos de orientação espacial no ambiente e como essas informações são arquivadas, no sistema nervoso. A utilização deste mapa possibilitaria aos animais localizarem-se dentro do seu ambiente, identificando diferentes locais, como por exemplo, onde encontrar alimento, e traçar os melhores caminhos para alcançá-los. Sua constituição dependeria da capacidade dos animais em identificar e estabelecer múltiplas relações entre os estímulos do ambiente e de representá-las em seu sistema nervoso.

Essencialmente, O'Keefe e Nadel (1978) sugerem que os animais aprendem relações (espaciais) existentes entre os objetos e utilizam essas relações para se localizarem em um determinado ambiente. O mapa de um ambiente é composto por um conjunto de representações de lugares conectados entre si de acordo com as regras que representam as distâncias e direções entre os lugares. Segundo a teoria do mapa cognitivo, locais e espaços não existem no mundo físico, mas são noções construídas pelo cérebro, no sentido de organizar as entradas sensoriais. Um pequeno número de estímulos (2 ou 3) ocorrendo com uma configuração espacial única quando o animal está em uma parte específica do ambiente, é suficiente para a identificação de um local (lugar) no mapa. Em qualquer ambiente existe normalmente um grande número de estímulos e, assim, a identificação de um determinado local não depende de qualquer pista (ou objeto) ou grupo de pistas em particular. $\mathrm{O}$ animal parece detectar as múltiplas relações entre os objetos e estímulos do ambiente, independentemente de sua própria localização, como se dispusesse de um mapa alocêntrico daquele ambiente. Esse mapa seria construído por meio da atividade exploratória, durante a qual o animal estabelece triangulações entre pares de estímulos e ele próprio como um dos vértices; múltiplas triangulações seriam registradas. Porém, como o sistema 
nervoso é capaz de detectar que essas relações se alteram com o próprio deslocamento, e são estabelecidas múltiplas relações envolvendo os estímulos disponíveis, esse mesmo sistema nervoso "subtrai" o próprio animal das relações resultando num mapa alocêntrico que representa aquele ambiente.

Os mapas são formados durante a exploração do ambiente pelos animais, eles podem ser utilizados pelos animais para se localizarem no ambiente, localizarem itens (ou eventos) neste ambiente, incluindo recompensas e punições, ou ainda para se locomoverem de um local para outro por qualquer rota disponível.

Se um animal está faminto, o mapa do ambiente no qual ele encontra-se pode ser consultado para verificar se há uma representação de alimento naquele ambiente. Se houver, então o mapa pode ser usado para gerar um programa motor, o qual levará o animal, da sua posição atual no mapa, para a localização do alimento.

Segundo a teoria do mapa cognitivo, a formação hipocampal $(\mathrm{FH})$, participa da codificação do ambiente em mapas cognitivos, e contribui também para o armazenamento dessas informações (O'Keefe e Nadel, 1978). Ainda, segundo esses autores, outros dois sistemas utilizados na orientação espacial, independem da formação hipocampal; o sistema de táxon em que a orientação ocorre com base num estímulo preponderante, envolvendo estratégias de guiamento, e o sistema de orientação egocêntrico, que envolve rotações do próprio eixo do corpo.

Estratégias de guiamento envolvem a aproximação ou distanciamento de estímulos particulares; assim, é possível treinar um animal a mover-se em uma direção arbitrária em relação a um estímulo proeminente que indica a localização do alvo. Os animais não precisam estabelecer relações espaciais entre os objetos; eles orientam-se em relação a uma pista específica. Por exemplo, próximo ao local que o animal deve alcançar para encontrar a plataforma no labirinto aquático de Morris, há um objeto saliente de forma quadrada, fixado na parede. Assim, o animal pode orientar-se sem estabelecer qualquer tipo de relação entre esse estímulo saliente e os demais estímulos da sala para se situar no ambiente. A hipótese de guiamento identifica um objeto ou uma pista no ambiente da qual deve 
aproximar-se ou afastar-se. O componente motor não é especificado em detalhes. Exemplos para essa estratégia são: ir para a luz, seguir aquele carro. Neste caso, os sujeitos precisam estabelecer relações espaciais entre objetos e eventos, eles orientam-se em direção a uma pista específica.

Estratégias de orientação egocêntricas envolvem rotações do eixo do próprio corpo em relação a algum eixo conhecido. Os animais orientam-se a partir de informações egocêntricas e aprendem seqüência de movimentos corporais. Por exemplo, o animal aprende que é necessário girar para a direita, em rotação de $50^{\circ}$, depois de deslocar-se certa distância, para atingir seu alvo. Para utilizar desta estratégia, tomando como exemplo o labirinto aquático de Morris, o animal, partindo do mesmo ponto da borda da piscina, deveria aprender sobre as rotações corpóreas necessárias que teria que realizar para encontrar a plataforma submersa. As estratégias de guiamento e de orientação, segundo esta teoria, independem da integridade da formação hipocampal. As hipóteses de orientação (orientação corpórea ou estratégia corpórea egocêntrica) especificam o comportamento motor em detalhes. Elas envolvem rotações corpóreas egocêntricas em resposta a uma pista ou informação. Os animais orientam-se a partir de informações egocêntricas e aprendem uma seqüência de movimentos do corpo. Por exemplo, virar $90^{\circ}$ para a direita, olhar para a esquerda $15^{\circ}$.

Duas das mais importantes propriedades do sistema de táxon são: (1) as informações são armazenadas segundo sua categoria de inclusão e (2) as alterações das informações ocorrem de forma gradual. Um sistema de inclusão de categorias armazena dois eventos (ou itens) com características similares no mesmo (ou muito próximo) circuito neural. Isto resulta em possíveis interferências quando um mesmo evento (ou item) está associado a outros eventos, em momento ou contextos diferentes.

O armazenamento gradual, isto é, cada ativação da informação resulta em pequena mudança na força das conexões sinápticas, varia com o tempo que se segue à ativação de uma hipótese de táxon. Assim, este postulado da teoria prevê que o comportamento dos animais que esteja baseado em hipótese de táxon será significativamente influenciado por intervalos entre tentativas. 
No sistema de mapeamento cognitivo, os animais utilizam a estratégia de lugar (alocêntrica) para se localizarem no ambiente. A estratégia de lugar requer mapa cognitivo, o conhecimento das posições (espaciais) relativas entre os vários estímulos do ambiente, obtido por meio de atividade exploratória. Por exemplo, numa sala onde se localiza o labirinto aquático de Morris existem várias pistas, "estímulos salientes diferentes entre si", fixados nas paredes para que os ratos as visualizem e a partir dessas construam um "mapa cognitivo" para se localizarem espacialmente. Ou seja, os animais se baseiam nas relações espaciais existentes entre essas pistas, não dependendo de qualquer uma delas exclusivamente, conseguindo assim navegar na piscina por meio de um mapa cognitivo, e a partir daí encontrar a plataforma para escapar da água. Essa estratégia permite a navegação para um dado local a partir de diferentes pontos de partida, e a adoção de um trajeto novo quando o caminho conhecido não está disponível. Além disso, a remoção de algumas pistas não impede a orientação espacial desde que algumas poucas pistas utilizadas na elaboração do mapa cognitivo (alocêntrico) sejam mantidas em suas posições.

Nas tarefas espaciais ou em outras tarefas, os animais podem estar resolvendo-as por meio de uma ou mais estratégias. Quando os animais são privados do seu hipocampo, e assim, do seu sistema de mapeamento, sendo incapazes da utilização da estratégia de lugar, podem solucionar as tarefas, por meio de outras duas estratégias (de guiamento e/ou orientação). Nas tarefas cuja solução depende da estratégia de lugar seriam encontradas deficiências nos animais com lesões hipocampais. Quando outras estratégias predominam ou são igualmente úteis, não deve haver prejuízo no desempenho dos animais lesados. Por outro lado, existem tarefas nas quais certos conflitos só podem ser resolvidos a partir da utilização da estratégia de lugar. Nestes casos, os animais lesados, para os quais apenas as outras estratégias estariam disponíveis, não conseguem ter um desempenho adequado na tarefa.

O labirinto aquático de Morris vem sendo amplamente utilizado em estudos envolvendo memória espacial em roedores (Santos, 1999). A tarefa consiste em o rato encontrar uma plataforma submersa, não visível, em determinada localização 
dentro de uma piscina, a fim de escapar da água. Whishaw e Mittleman (1986) mostraram que ratos normais são capazes de utilizar estratégias de lugar, de orientação e de guiamento simultaneamente para solucionar a tarefa de navegação espacial no labirinto aquático de Morris. Ratos treinados a buscar a plataforma partindo de diferentes pontos da borda da piscina devem aprender sobre as posições relativas dos estímulos distais e da plataforma submersa em relação a esses estímulos de modo a desempenhar a tarefa; isto demanda o uso da estratégia de lugar (que envolve orientação alocêntrica). Diferentemente, ratos treinados partindo de um único ponto da borda da piscina podem utilizar estratégias de guiamento e/ou de orientação. Além disso, se a localização da plataforma é mantida constante ao longo das sessões de treino, é possível avaliar a memória de referência espacial (um tipo de memória de longa duração; o animal deve diariamente procurar a plataforma no mesmo local, que assim independe do contexto temporal). Por outro lado, se a plataforma é apresentada numa localização diferente a cada dia, com pelo menos duas tentativas por dia, é possível avaliar a memória operacional espacial.

Segundo outros autores, Olton (1979) e Olton e col. (1979), o tempo cronológico não seria o fator determinante sobre a manutenção ou não de uma informação, mas sim o processamento inicial que a originou. Informações apresentadas em contextos temporais específicos seriam manipuladas por um sistema de memória denominado operacional, sendo as informações, mantidas por períodos de tempo durante os quais fossem relevantes, devendo posteriormente ser ativamente apagadas, para evitar a sobrecarga do sistema (Walker e Olton, 1984). A memória operacional espacial (Olton e col., 1979) pode ser avaliada numa versão modificada do labirinto aquático. A estratégia consiste em alterar a localização da plataforma a cada dia, porém, nas demais tentativas do mesmo dia, os animais podem valer-se das informações coletadas na primeira tentativa para dirigirem-se a plataforma. Como a localização da plataforma muda a cada dia de forma aleatória, as informações específicas sobre a localização da plataforma em uma sessão são irrelevantes para as demais sessões, podendo ser descartadas, caracterizando o uso da memória operacional (Xavier e Oliveira- 
Filho, 1995). Olton (1990) afirma que em toda aprendizagem há dois tipos de memória que organizam as informações.

Seguindo a terminologia de Honig $(1978,1982)$, Olton sugere que o contexto específico, pessoal e temporal de uma situação é codificado na memória operacional (working memory). Ela constitui processo mnemônico responsável pela codificação de informações acerca do contexto temporal no qual o evento ocorre, distinguindo um instante dentro de um conjunto de eventos. Como resultado, a memória operacional é muito propensa às interferências de efeitos temporais. Em contraste, a memória de referência (reference memory) é o processo mnemônico responsável pela codificação das informações que não requerem associações com o contexto temporal. Diferentemente da memória operacional, a memória de referência generaliza através dos instantes é menos propensa à interferência temporal, isto é, na memória de referencia as associações aprendidas independem do contexto temporal e podem ser utilizadas a qualquer momento dependendo dos aspectos não temporais do contexto.

Olton $(1986,1990)$ propõe que o hipocampo e suas interconexões mediam a memória operacional, enquanto algum outro sistema mediaria a memória de referência.

Vários experimentos realizados a partir de lesões de estruturas do sistema hipocampal e/ou seus eferentes e aferentes, sugerem o envolvimento da formação hipocampal com a memória operacional, e não com a memória de referência, independente das informações envolvidas no contexto experimental serem temporais ou espaciais (Meck, Church e Olton, 1984; Olton, 1986). Assim, segundo Olton e outros autores, o sistema hipocampal, está diretamente envolvido na memória operacional temporal ou espacial, embora esta estrutura não seja requerida pela memória de referencia (Meck et al., 1987; Markowaska et al., 1989; Murray et al., 1989) um tipo de memória temporária em que o animal deve, a cada dia, procurar pela plataforma em um local diferente do dia anterior; assim esse tipo de memória é dependente do contexto espacial e temporal específico, e pode ser apagado após o uso. Isto é na memória operacional espacial, a informação sobre a localização da plataforma adquirida na primeira tentativa do dia é utilizada na 
segunda e demais tentativas do mesmo dia para facilitar o desempenho do animal, mas deixa de ser útil quando as tentativas daquele dia são concluídas (Olton, 1983; Santos, 1999); ademais, o intervalo de tempo entre as tentativas pode ser variado, permitindo avaliar também o tempo de retenção da informação espacial.

A literatura descreve a formação hipocampal como desempenhando um papel importante no processamento da memória (Scoville, 1957; O’Keefe e Nadel, 1978; Olton e col., 1979; Gray, 1982), particularmente na memória espacial (Olton e col., 1979; O’Keefe e Nadel, 1978).

A formação hipocampal, principalmente as subregiões, CA1 e CA3 apresentam alterações eletrofisiológicas durante os processos de aprendizado, tanto em animais, com em seres humanos (Skelto, 1987); alterações semelhantes ocorrem quando se avalia as funções hipocampais durante a exploração de um novo ambiente (Moser, 1995), bem como em condições de estresse e geração de ansiedade (Gray, 1982). Animais que apresenta territorialidade, movimentos migratórios ou necessitam precisão de localização espacial, apresentam regiões hipocampais comparativamente mais desenvolvidas que espécies evolutivamente comparáveis, fato que vem a reforçar propostas sobre o envolvimento do hipocampo com funções de localização espacial (Moser e col., 1998).

\subsection{ANSIEDADE E MEDO}

O comportamento de defesa e a natureza dos sinais de ameaça variam com a espécie ou gênero do animal, porém algumas estratégias padronizadas são adotadas em função dos diferentes níveis de ameaça com que o animal se defronta no seu meio ambiente.

No momento em que o animal deixa a área segura para explorar uma área mais perigosa, ocorre o primeiro nível de defesa. $O$ animal pode fazer isso de maneira cautelosa, frente a um perigo potencial/incerto. (Blanchard e Blanchard, 1988). Esse comportamento atende a duas funções básicas: obter informações 
que sinalizam que a ameaça não é iminente, propiciando assim, redução da defesa bem como de informações que permitam confirmar, identificar e localizar o perigo. Caso este não seja localizado ou confirmado, a investigação cautelosa se prolonga de forma imprevisível. Desta forma, se configuraria a ansiedade antecipatória ou condicionada. Essa reação de defesa é caracterizada por uma ansiedade inata. $O$ animal passa para o próximo nível de defesa, no momento em que um predador é encontrado. Para o rato esse nível é caracterizado pela resposta de congelamento (Fanselow et al., 1988). Se o predador se aproxima (perigo próximo), o congelamento é interrompido e o animal passa para o terceiro nível de defesa, com ataque com saltos e mordidas (Blanchard et al., 1986).

Para Gray e McNaughton (2000) o congelamento, a luta e a fuga desordenada fariam parte dos níveis primários. Esses comportamentos seriam resultantes do perigo próximo onde há pouco tempo para análise da situação. $O$ próximo nível seria caracterizado por fuga ordenada resultante de um perigo identificado, porém distal; neste nível há mais tempo para a análise da situação e uma maior variedade de respostas possíveis. O comportamento de esquiva ativa ocorre quando o perigo é potencial e há a necessidade de ser evitado; neste nível, a análise e programação motora atingiriam altos níveis de abstração e poderia envolver condicionamento.

A inibição comportamental com a avaliação de risco ocorre quando o perigo é potencial, mas há uma tendência de aproximação. Nessa situação é gerado um alto nível de conflito, onde há a necessidade do processamento da informação pelas estruturas que medeiam às tendências de esquiva e aproximação, e por aquelas que seriam responsáveis pelo nível mais complexo, atuando na resolução do conflito, com a definição da resposta mais apropriada após a comparação das tendências distintas.

Em ratos selvagens, o comportamento antipredatório está organizado em função da disponibilidade de fuga e da distância entre o predador e a presa. A fuga é a resposta predominante se existe a possibilidade do predador aproximarse e ainda existe uma distância segura para fugir. No momento em que a fuga não é possível devido a pouca distância entre os dois animais, o congelamento é o 
comportamento de defesa inicial, seguido da ameaça defensiva, onde ocorre a vocalização com exposição dos dentes. Quando o predador continua a se aproximar, o animal emite um salto explosivo de ataque. Esse salto pode resultar em uma mordida no predador, seguido imediatamente pela fuga (Blanchard e Blanchard, 1987).

O medo e a ansiedade são comportamentos distintos incluídos no repertório da reação de defesa dos animais.

Robert e Caroline Bianchard, avaliando as respostas defensivas comportamentais de roedores (ratos e camundongos), em confronto com os predadores classificaram as estratégias comportamentais exibidas de acordo com o nível de ameaça, sendo estas; ameaça real ou potencial (Blanchard e Blanchard, 1988; Blanchard et al.,1987). Esses pesquisadores definiram como respostas de medo àqueles comportamentos evocados na presença do predador (perigo real), e como respostas de ansiedade, os comportamentos evocados, na ausência do predador (perigo potencial), por sinais associados ao mesmo, como por exemplo, seu odor.

Comportamentos distintos são observados em diferentes distâncias do predador; quando este estiver próximo do animal, surgem respostas relacionadas ao medo e no momento em que este estiver distante, surgem comportamentos relacionados à ansiedade. Reações de congelamento, vocalizações, ataques defensivos com saltos e auto-limpeza, podem ser indicativas de medo, e reações defensivas induzidas por estímulos onde ocorreram situações prévias de ameaça, não duradouras, são indicativas de ansiedade (Blanchard e Blanchard, 1987; 1988).

\subsubsection{ANSIEDADE}

A ansiedade pode ser compreendida como um estado emocional que resulta de sentimentos de apreensão, incerteza e medo, freqüentemente experimentados na espécie humana e outros mamíferos (Darwin, 1872). Esses 
sentimentos são normalmente referidos como desconfortáveis e são, em grande parte, acompanhados por diversas alterações fisiológicas, comportamentais e psicológicas, tais como taquicardia, sudorese, hiperventilação, aumento da tensão muscular, inquietude e alerta (Nutt, 1990).

A ansiedade, quando manifestada em níveis adequados, parece ser importante para a motivação de um bom desempenho do indivíduo, ativando e mobilizando o organismo à sua adaptação ao ambiente. Por outro lado, quando se torna excessiva, a ansiedade pode ser considerada patológica prejudicando o desempenho (Dratcu e Lader, 1993; Graeff e Brandão, 1999). Segundo Dratcu e Lader (1993), altos níveis de ansiedade podem conduzir o indivíduo à exaustão e, consequentemente, à formação de sintomas psicossomáticos.

Com a utilização de modelos animais de ansiedade, é possível reproduzir em laboratório aspectos da sintomatologia, etiologia, ou de possíveis tratamentos para a ansiedade, bem como os mecanismos pelos quais estes compostos produzem seus efeitos (Treit, 1985; File, 1992).

Há dois principais grupos de modelos animais de ansiedade; sendo o primeiro baseado em medos inatos (etologicamente fundamentados) e o segundo baseado em aprendizagem associativa.

Nos modelos etologicamente fundamentados, os estímulos desencadeiam respostas incondicionadas de medo, frente a situações e/ou estímulos que são naturalmente aversivos como, por exemplo, lugares novos ou intensamente iluminados, a presença de co-específicos e o confronto com predadores. Dentre estes modelos, pode-se citar a transição claro-escuro, a interação social, o labirinto em cruz elevado e à interação presa-predador.

Vários modelos animais de ansiedade envolvem processos de aprendizagem associativa baseados no condicionamento clássico e/ou operante do medo. No condicionamento clássico, os estímulos neutros (condicionados), como por exemplo, sons de baixa intensidade e luzes, quando associados a estímulos aversivos (incondicionados), como choques elétricos e sons intensos, podem desencadear respostas de medo/ansiedade (resposta condicionada). A partir daí, esses estímulos neutros passariam a desencadear as respostas de 
medo/ansiedade em decorrência de anteciparem para o animal a apresentação de um estímulo aversivo. No condicionamento operante, os animais aprendem determinadas estratégias ou tarefas, a fim de diminuir ou suprimir as conseqüências negativas associadas com a apresentação real de estímulos aversivos. A situação de punição ocorre, quando as respostas dos animais são seguidas de apresentação do estímulo aversivo, há desta maneira diminuição da expressão deste comportamento no futuro. Caso as respostas sejam seguidas pela retirada do estímulo aversivo, ocorre a fuga e, quando são seguidas pela evitação da apresentação do estímulo aversivo, acontece à esquiva. Entre os modelos baseados em aprendizagem associativa estão à resposta emocional condicionada, resposta de sobressalto intensificada pelo medo, o teste de conflito do beber punido e punição de pressão à barra (Geller e Seifter, 1960; Vogel et al., 1971).

A origem da ansiedade e de outras alterações emocionais está intimamente relacionada com as reações de defesa dos animais, as quais ocorrem em resposta a estímulos ou situações de perigo normalmente encontrado no ambiente em que vivem (Graeff e Guimarães, 1999).

\subsubsection{MEDO}

No momento em que um animal é confrontado com ameaça à sua integridade física ou à própria sobrevivência (representada pelo predador, agressor da mesma espécie ou pela mudança no ambiente), este apresenta um conjunto de respostas comportamentais e neurovegetativas que caracterizam a reação de defesa. A reação de defesa é o resultado de alterações do padrão comportamental e cardiovascular diante de estímulos ameaçadores ou estressantes (Bandler e Carrive, 1988).

Em ratos e camundongos a reação de defesa mais comum é o congelamento. O congelamento é um padrão comportamental complexo e 
coordenado caracterizado pela ausência de todos os movimentos corporais, exceto movimentos respiratórios (Bolles e Collier, 1976). Esse comportamento é uma maneira efetiva de evitar um provável perigo, quando a fuga e a esquiva são impossíveis. A aprendizagem também desempenha um papel importante quando um estímulo ativa o sistema de medo.

O tempo de congelamento pode oferecer um método bastante conveniente e sensível para o estudo do medo condicionado (Bouton e Bolles, 1980; Fanselow e Baackes, 1982). Nessa condição ocorrem também alterações autonômicas como aceleração dos batimentos cardíacos e aumento da freqüência respiratória (Hoffer, 1970).

Observa-se que todos os animais apresentam congelamento depois do choque, mas há variabilidade considerável quanto ao momento em que se inicia este comportamento (Bolles e Riley, 1973). Estudos referem que com um aumento na intensidade ou duração do choque, há aumento na agressão (Azrin et al., 1964; Dreyer e Church, 1968; Fanselow et al., 1980; Fanselow, 1986).

No condicionamento aversivo Pavloviano, a apresentação de estímulo inicialmente neutro como, por exemplo, som, luz é pareada com um evento aversivo, como por exemplo, choque nas patas. Com o treino o animal passa a eliciar respostas que tipicamente ocorrem na presença de perigo, tais como comportamentos defensivos (resposta de congelamento), respostas autonômicas (mudança de pressão arterial e batimentos cardíacos), respostas neuroendócrinas (liberação de hormônios das glândulas adrenais e da pituitária), entre outras.

O aprendizado sobre um contexto parece envolver a integração de uma multiplicidade de estímulos elementares, de uma variedade de modalidades, em uma única representação. Desta forma, após o condicionamento a um contexto, as respostas condicionadas não são eliciadas por componentes únicos do contexto, mas pela configuração completa dos elementos. Quando um animal recebe um choque nas patas imediatamente depois que é colocado no aparelho de condicionamento, posteriormente ele não exibirá respostas condicionadas de medo àquele contexto - este fenômeno é chamado de prejuízo do choque imediato. 
A resposta condicionada de congelamento aumenta linearmente com 0 aumento do intervalo entre a introdução do animal no aparelho de treino e a liberação do choque nas patas (até dois minutos). A pré-exposição ao contexto um dia antes do imediato condicionamento aversivo também resulta em aumento da resposta condicionada de congelamento; efeito de facilitação pela préexposição ao contexto. Além disso, a pré-exposição a todos os elementos do contexto, em separado, não melhora o condicionamento ao contexto (Rudy et al., 2004). Portanto, para que um ambiente ou contexto possa ser condicionado aversivamente, faz se necessário a formação de uma representação configuracional dos vários elementos do ambiente, a qual seria então associada com a representação do estímulo incondicionado e ainda, que certo período de tempo seria imprescindível para a construção dessa representação (Fanselow, 1990).

A aquisição do condicionamento clássico aversivo ao contexto parece envolver também o aprendizado configuracional sobre os múltiplos elementos constituintes do contexto em questão. Estudos evidenciam que a integridade funcional do hipocampo é crítica para a aquisição e a consolidação da representação unificada de um contexto (O'Keefe e Nade, 1978; Nadel et al., 1985; Rudy e Sutherland, 1989). Tem sido sugerido que o papel do hipocampo no medo condicionado seria 0 de promover a transferência de uma configuração espacial do contexto para a amígdala, onde ocorreria então, a sua associação com os choques (estímulo incondicionado), determinando o processo de condicionamento (Sutherland e McDonald, 1990; Fendt e Fanselow, 1999). Lesões pós-treino do hipocampo também induzem diminuição no comportamento de congelamento, mas esse efeito é menos pronunciado conforme se aumenta o intervalo entre o treino e lesão (Maren et al., 1997).

Lesões no hipocampo, tanto eletrolítica quanto neuroquímica, levam a diminuição no condicionamento contextual de medo (Maren et al., 1997; Fanselow, 2000). Além disso, foi sugerido o envolvimento hipocampal na aquisição da memória contextual, já que lesões dessa estrutura bloqueiam o desempenho em tarefas que requerem a aprendizagem e memória de relações espaciais (Olton et 
al., 1979; Morris et al., 1986; Gewirtz et al., 2000; Maren e Holt, 2000; Chen et al., 2001; Redish, 2001).

Para Gray (1987), o hipocampo é uma estrutura que funciona como um comparador que avalia estímulos atuais e estímulos esperados, ativando, em situações aversivas, os comportamentos mais adequados. Os animais que apresentam o hipocampo lesado deixam de reconhecer o estímulo estressor como ameaçador, aumentando, assim, sua atividade exploratória, não somente em situações aversivas (no caso dos braços abertos no labirinto em cruz elevado e o lado claro do teste claro-escuro), como também após exposição prévia a um estímulo estressante, como, por exemplo, a imobilização (Andrade et al., 1999). De fato, existem fortes evidências de que o hipocampo está envolvido na aprendizagem das características contextuais em que o condicionamento ocorre (Marren et al., 1997; Fanselow, 2000; Gewirtz et al., 2000; Maren e Holt., 2000). 


\subsection{OBJETIVOS}

\section{OBJETIVO}

O objetivo deste estudo foi avaliar os efeitos da anóxia neonatal, em modelo animal desenvolvido em nosso laboratório, quanto a possíveis alterações comportamentais, em ratos adultos.

\subsection{Objetivos específicos}

Os objetivos específicos estabelecidos no presente estudo foram:

1 - Avaliar eventuais alterações de memória de referência espacial, no labirinto aquático de Morris em ratos Wistar adultos, submetidos à anóxia neonatal; 2 - Avaliar eventuais alterações de memória operacional com diferentes intervalos entre as tentativas (zero, dez e trinta minutos), no labirinto aquático de Morris, em ratos Wistar adultos, submetidos à anóxia neonatal;

3 - Avaliar alterações sensoriais no labirinto aquático com plataforma visível, em ratos Wistar adultos, submetidos à anóxia neonatal;

4 - Avaliar eventuais alterações da ansiedade em ratos Wistar adultos, submetidos à anóxia neonatal, pelo labirinto em cruz elevado;

5 - Avaliar eventuais alterações a aquisição do medo condicionado ao som e ao contexto, em ratos Wistar adultos, submetidos à anóxia neonatal, pelo teste de medo condicionado ao contexto e pelo teste de medo condicionado ao som. 


\subsection{Sujeitos}

Para o procedimento da anóxia neonatal, foram utilizados 25 ratos albinos (Ratus norwegicus, linhagem Wistar), divididos em dois grupos, Anóxia ( $n=13)$ e Controle $(n=12)$, machos, neonatos (aproximadamente 30 horas de vida, pesando de 6 a $8 \mathrm{~g}$ ), criados no biotério do Instituto de Ciências Biomédicas III - USP, com temperatura constante $\left(23^{\circ} \mathrm{C} \pm 1{ }^{\circ} \mathrm{C}\right.$ ), ciclo claro/escuro de 12:12h, início do claro às 7:00h, e água e comida ad libtum. Os animais foram mantidos junto aos pais até o início do experimento. Os procedimentos descritos estão de acordo com os Princípios Éticos de Experimentação Animal adotado pelo Colégio Brasileiro de Experimentação Animal (COBEA) e foram aprovados pela Comissão de Ética em Experimentação Animal (CEEA) (Protocolo $n^{\circ}$ 134, fls. 38 do livro 2 para uso de animais em experimentação).

Os mesmos animais (grupo anóxia e grupo controle) descritos acima, à partir de 60 dias de idade, foram submetidos aos testes para avaliar a memória de referência espacial, memória operacional com intervalos entre as tentativas de dez minutos, trinta minutos e zero e plataforma visível no labirinto aquático de Morris. Estes, posteriormente, foram submetidos ao teste no labirinto em cruz elevado, treino de condicionamento clássico aversivo, teste de medo condicionado ao contexto e teste de medo condicionado ao som.

Os animais foram submetidos às tarefas com as seguintes idades no início do experimento:

- Sessenta dias de idade os animais tiveram início à tarefa de memória de referência espacial, no labirinto aquático de Morris;

- Setenta e três dias de idade, tiveram início à tarefa de memória operacional com intervalo de dez minutos entre as tentativas, no labirinto aquático de Morris;

- Oitenta e dois dias de idade, tiveram início às tarefas de memória 
operacional com intervalo de trinta minutos entre as tentativas, no labirinto aquático de Morris;

- Oitenta e nove dias de idade, tiveram início às tarefas de memória operacional com intervalo zero entre as tentativas, no labirinto aquático de Morris;

- Noventa e cinco dias de vida, tiveram início às tarefas com plataforma visível, no labirinto aquático de Morris;

- Com cento e um dias de idade, teve-se início ao teste do labirinto em cruz elevado;

- Cento e seis dias, teve-se início ao treino de condicionamento aversivo;

- Cento e sete dias de idade, teve-se início ao teste de medo condicionado ao contexto;

- Cento e oito dias de idade, teve-se início ao teste de medo condicionado ao som.

\subsection{Condições experimentais para a anóxia neonatal}

Para a exposição dos animais à anóxia neontal, foi utilizada câmara semihermética de policarbonato $(31,0 \times 14,0 \times 19,5 \mathrm{~cm})$, adaptada a partir da descrição de Tang e Nakazawa (2005), com entrada e saída de gás, acoplada a manômetro, fluxômetro e a cilindro de nitrogênio gasoso. Com o objetivo de evitar hipotermia e potencializar os efeitos da anóxia, a temperatura da câmara foi mantida entre $35^{\circ}$ e $37^{\circ} \mathrm{C}$ através da imersão parcial da mesma em água aquecida por resistência elétrica (Figura 1). Esta faixa de temperatura é importante uma vez que a temperatura basal dos neonatos é de $33^{\circ} \mathrm{C}$, constituindo por si só um fator de neuroproteção (Caputa et al., 2005; Rogalska et al., 2006). Os casais foram mantidos juntos até o nascimento dos filhotes, quando o macho foi transferido para outra gaiola, permanecendo na mesma gaiola, apenas a mãe com os neonatos.

Para a anóxia, primeiramente a câmara foi saturada completamente com nitrogênio $100 \%$ a um fluxo de $3 \mathrm{~L} /$ minuto e pressão de $101,7 \mathrm{kPa}$, determinados 
de acordo com a literatura (Tang e Nakazawa, 2005; Rogalska et al., 2006; Coq et al., 2007). Os animais foram então colocados rapidamente na câmara, permanecendo durante 25 minutos nestas condições, considerando o tempo máximo para não ocorrer morte dos neonatos (Dell’Anna et al., 1995).

Testes prévios realizados neste laboratório mostraram que períodos ligeiramente maiores causaram alto índice de mortalidade. Para o período considerado, o índice de mortalidade foi de 12,5\%, semelhante ao observado em literatura (Dell’Anna et al., 1991; luvone et al., 1996).

Após a recuperação dos animais (recuperação da coloração, da respiração e da movimentação ativa), que ocorreu em média 5 minutos após a retirada da câmara, estes foram devolvidos para a mãe até o desmame (21 dias) e posteriormente foram mantidos em caixas de polietileno (medindo $40 \times 33 \times 16 \mathrm{~cm}$ ) forradas com maravalha (serragem) com 2 ratos cada uma.

O grupo controle foi exposto às mesmas condições experimentais, no entanto não houve a troca do ar dentro da câmara, ou seja, permaneceram ao ar ambiente. O modelo experimental escolhido para provocar anóxia nos neonatos já foi utilizado e consagrado pela literatura (Herschkowitz et al., 1983; Yamamoto e Kato, 1986; Dell'Anna et al., 1993; Dell'Anna et al., 1995; Buwalda et al., 1995; luvone et al., 1996; Nakajima et al., 1996; Speiser et al., 1998; Dell'Anna et al., 1997; Nakajima et al., 1999; Rogalska et al., 2004; Strata et al., 2004; Sandagernielsen et al., 2004; Laviola et al., 2004; Bohr, 2004; Caputa et al., 2005; Tang e Nakazawa, 2005; Rogalska et al., 2006; Coq et al., 2008). 


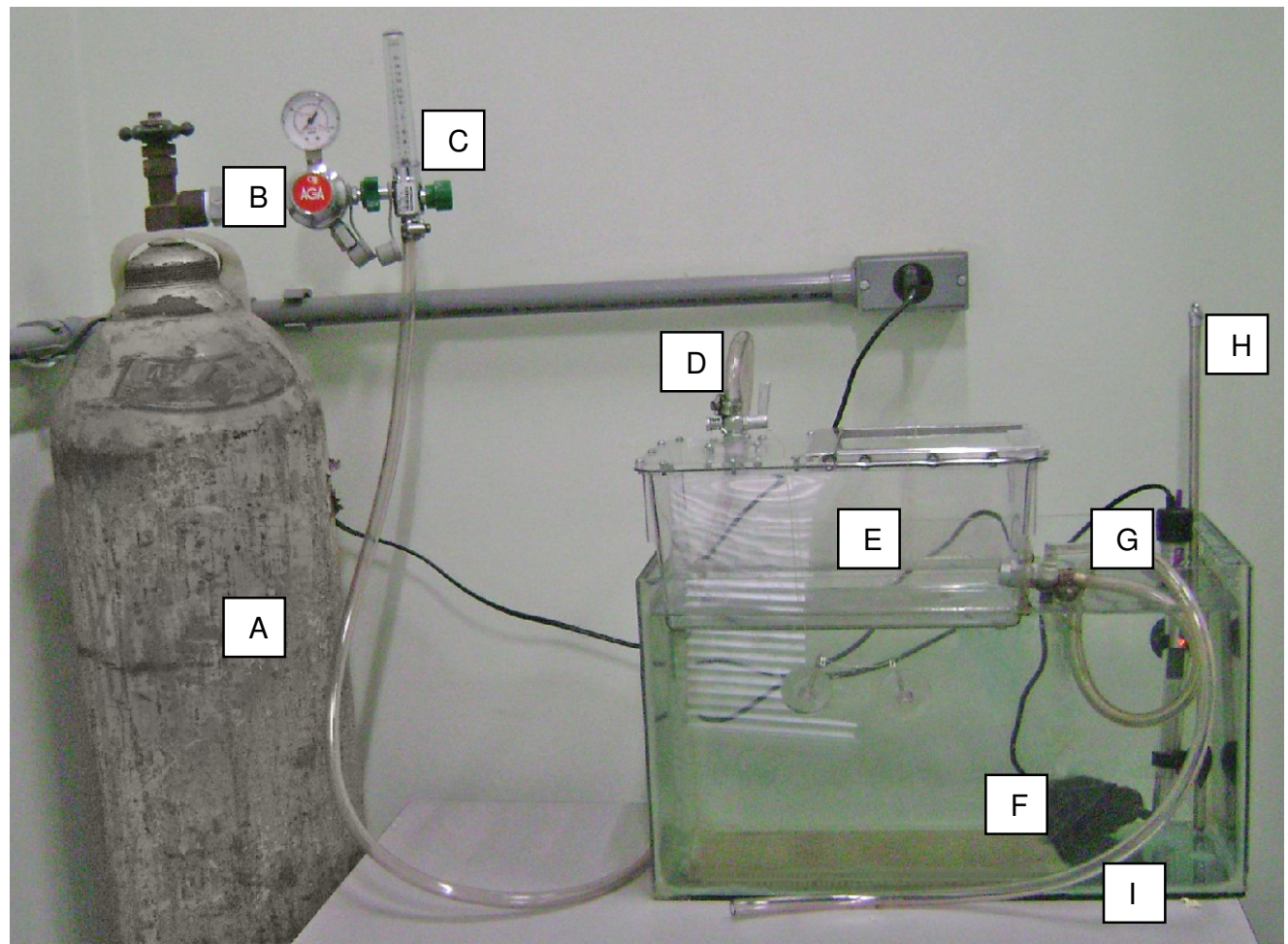

Figura 1. Sistema utilizado para provocar anóxia nos ratos neonatos. A - cilindro de nitrogênio gasoso (concentração de 100\%); B - manômetro; C - fluxômetro; D - entrada de gás; E - câmera em policarbonato parcialmente imersa na água; F -bomba difusora de água (para homogeinizar a temperatura da água); $\mathrm{G}$ - resistência para aquecimento de água; $\mathrm{H}$ - termômetro; I - saída do gás.

\subsection{Testes comportamentais}

No presente estudo, utilizou-se o labirinto aquatico de Morris para avaliar o desempenho dos ratos do grupo anóxia e grupo controle, quanto à memória de referência, memória operacional com diferentes intervalos entre as tentativas (dez, trinta e zero) e plataforma visível, sendo que a motivação envolvida no desempenho destas tarefas foi sair da água.

O labirinto em cruz elevado foi utilizado para avaliar os níveis de ansiedade em ambos os grupos, por meio do paradigma de teste e re-teste; paralelamente, avaliou-se também a atividade locomotora e o comportamento de avaliação de risco no mesmo paradigma comportamental.

Foi realizado treino de condicionamento clássico aversivo na caixa de esquiva inibitória, e posteriormente os testes de medo condicionado ao contexto e medo condicionado ao som. 


\subsubsection{Labirinto aquático de Morris}

O labirinto aquático de Morris consiste de uma piscina circular, construída em fibra de vidro, de $200 \mathrm{~cm}$ de diâmetro e $50 \mathrm{~cm}$ de profundidade, que repousa sobre uma armação de madeira. As paredes internas são pretas de modo a tornálas homogêneas. A piscina foi mantida em uma sala medindo 3,0 x 3,0 com vários estímulos salientes nas paredes, além do experimentador que se posicionava em um mesmo local da sala durante todo o período de experimento (Figura 2).

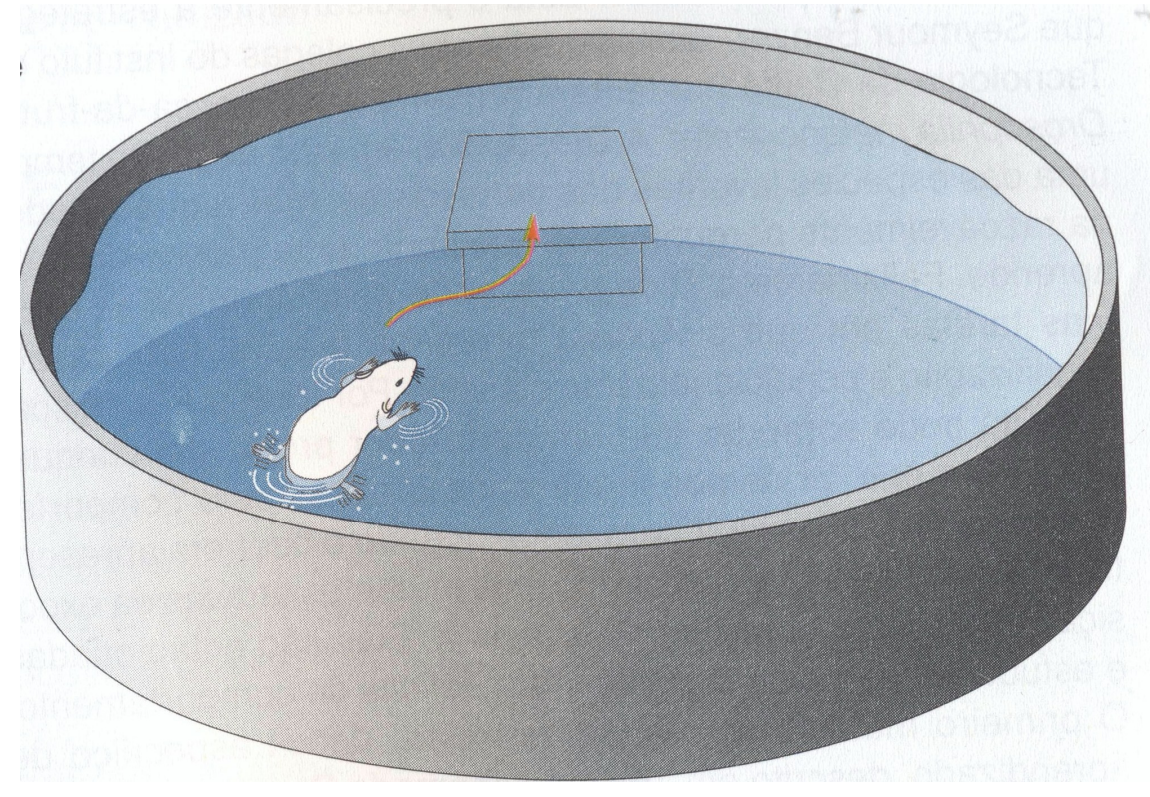

Figura 2. Representação esquemática do Labirinto aquático de Morris (Adaptado de Bear, 2002).

A cada dia de treino a piscina foi preenchida com água a $26^{\circ} \mathrm{C} \pm 1$ até a altura de aproximadamente $27 \mathrm{~cm}$. Uma plataforma foi colocada cerca de $1,5 \mathrm{~cm}$ abaixo do nível da água, construída de acrílico preto medindo $9 \mathrm{~cm}$ de diâmetro serviu como local para que os animais pudessem subir e escapar da água. Como não existam estímulos proximais indicando a localização da plataforma (a parede da piscina era homogeneamente preta). Nas tarefas de memória de referência espacial e na memória operacional (dez, trinta e zero entre as 
tentativas), o animal navegava com base em pistas distais, objetos fixados nas paredes da sala. Na tarefa com a plataforma visível, os animais navegavam em direção à plataforma (indicado pelo cilindro branco, que permaneceu acima da plataforma), e não com base nas pistas distais.

Uma câmera de vídeo posicionada aproximadamente a $180 \mathrm{~cm}$ acima do centro da piscina, conectada a um microcomputador, registrou e armazenou numericamente todos os dados referentes à trajetória dos animais dentro da piscina. O programa Ethovision (Noldus, versão 3) permitiu calcular diferentes parâmetros, incluindo (1) a latência, o tempo decorrido desde a liberação do animal na piscina até que ele encontre e suba na plataforma, (2) o comprimento do trajeto traçado na piscina e (3) a velocidade do nado.

Para a análise descritiva dos dados, a piscina foi dividida em quatro quadrantes com a mesma área, formados por linhas imaginárias, as quais se cruzam no centro da piscina, formando ângulos de $90^{\circ}$. As fronteiras dos quadrantes encontram-se na margem da arena e nas linhas imaginárias ligando o norte ao sul e o leste ao oeste. Pontos de partida arbitrariamente denominados $(\mathrm{N}),(\mathrm{S}),(\mathrm{E})$ e $(\mathrm{W})$, além de outros quatro pontos situados a nordeste $(\mathrm{R})$, noroeste $(T)$, sudoeste $(\mathrm{O})$ e sudeste (D), todos na borda da arena, foram utilizados. Toda a sala foi iluminada com luz indireta.

Na tarefa para avaliar a memória de referência espacial, a plataforma foi mantida em uma única localização, no centro do quadrante três, em todas as tentativas e durante todos os dias de treinamento.

Por outro lado, para avaliar a memória operacional com intervalo entre as tentativas (ITI) de dez, trinta e zero, a plataforma variou a cada dia de teste. A localização da plataforma a cada dia não era previsível de modo que os animais deveriam encontrá-la por acaso e/ou varredura. Nas demais tentativas do mesmo dia, os animais poderiam valer-se da primeira informação e melhorar seu desempenho, caso fossem capazes de reter a informação sobre a localização da plataforma naquele dia em sua memória operacional.

$\mathrm{Na}$ tarefa com a plataforma visível, a plataforma variou de localização a cada dia e tentativa de teste. 
Para avaliação da memória de referência espacial, cada animal foi submetido ao treinamento envolvendo quatro tentativas por dia, durante dez dias; o intervalo de tempo entre as tentativas (ITI) foi de dez minutos. O ponto de onde os animais foram liberados na piscina variou a cada dia e a cada tentativa, numa ordem aleatória e balanceada para não enviesar a busca espacial do animal.

Para avaliação da memória operacional, com intervalo entre as tentativas de dez minutos, cada animal foi submetido ao treinamento envolvendo três tentativas por dia, durante seis dias. Quando os intervalos entre as tentativas, foram de trinta e zero minuto, cada animal foi submetido ao treinamento envolvendo três tentativas por dia, durante quatro dias. Na tarefa com a plataforma visível, os animais foram submetidos ao treinamento envolvendo três tentativas por dia, durante três dias de testes.

Em todas as tarefas, em cada tentativa, o animal foi liberado de um dos pontos (dentre 8) da borda da piscina com o focinho voltado para a parede da piscina. No momento em que o animal era liberado pelo experimentador iniciavase o registro. Quando o animal subia na plataforma, o sistema de registro era desligado e o trajeto do animal na piscina, naquela tentativa, era gravado para posterior análise; o animal permanecia sobre a plataforma por cerca de 10 segundos. Se o animal não encontrasse a plataforma em até 120 segundos (que era a duração máxima de cada tentativa) ele era manualmente guiado até a plataforma pelo experimentador, onde permanecia por cerca de 10 segundos, findos os quais era transferido para uma caixa de espera até a próxima tentativa ou para sua própria gaiola ao final das tentativas daquele dia.

\subsubsection{Labirinto em cruz elevado}

O labirinto em cruz elevado (Figura 16) foi construído com acrílico branco, conforme as medidas descritas por Pellow et al. (1985); cada um dos quarto braços media $50 \mathrm{~cm}$ de comprimento e $10 \mathrm{~cm}$ de largura, sendo dois deles, opostos pelo centro, com paredes laterais de $40 \mathrm{~cm}$ de altura, denominados braços fechados, e dois deles, também opostos pelo centro, com paredes de $1 \mathrm{~cm}$ 
de altura, denominados braços abertos.

O aparelho foi apoiado em suportes ficando a $50 \mathrm{~cm}$ do assoalho em sala isolada. Todo o procedimento foi filmado por meio de uma câmera de vídeo ligada a um sistema de vídeo-cassete.

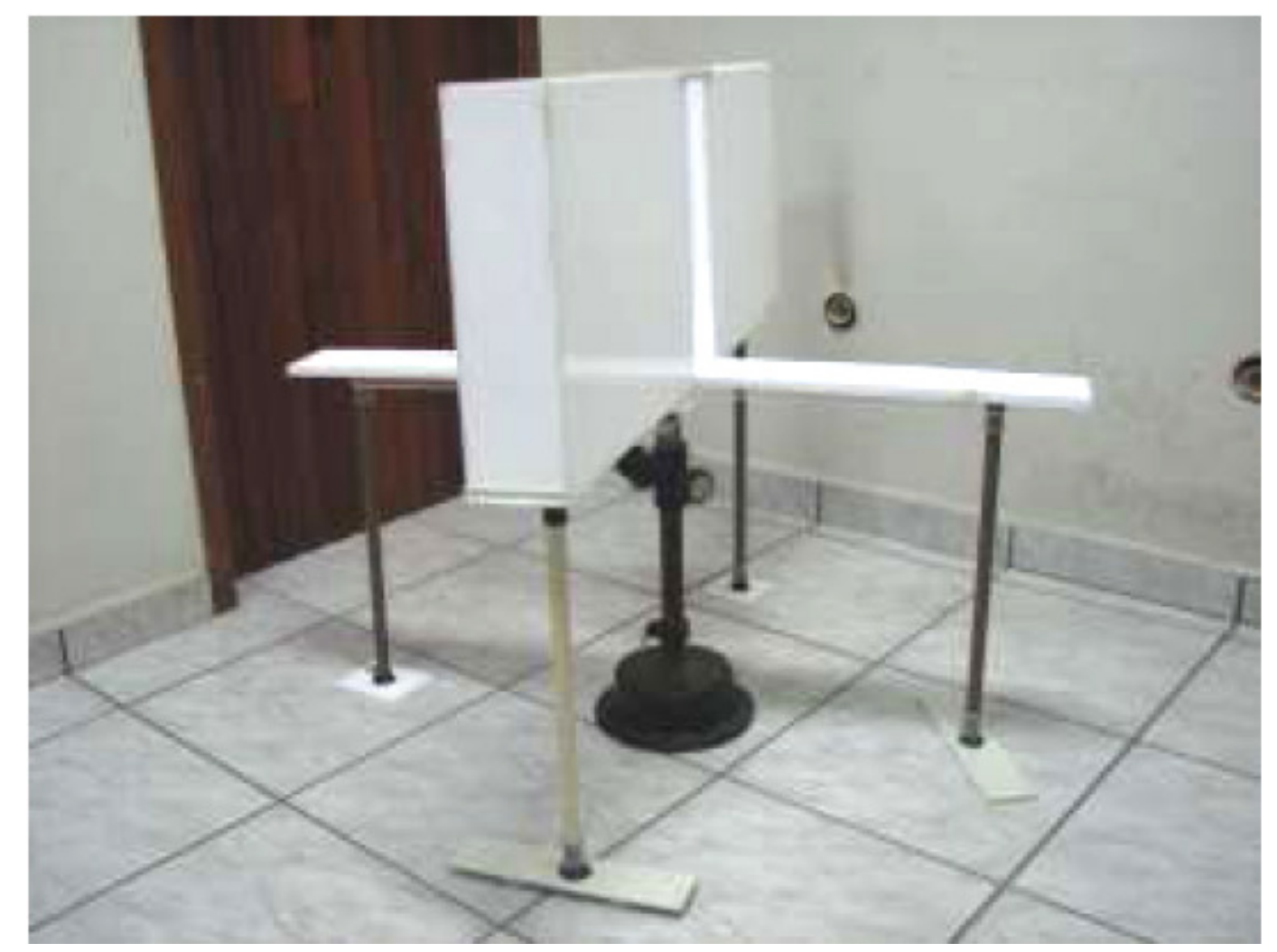

Figura 03. Fotografia do labirinto em cruz elevado utilizado para avaliar o nível de ansiedade.

Os animais foram individualmente colocados no centro do labirinto, podendo percorrê-lo livremente ao longo de cinco minutos (sessão um). Imediatamente após a colocação do animal no labirinto, o experimentador se retirava da sala, fazendo o monitoramento dos comportamentos do animal por meio da câmera de vídeo ligada a uma televisão; adicionalmente, a sessão foi registrada em fita de vídeo. Um programa computacional (X-Plo-Rat, versão 3.0) permitiu registrar o número de entradas nos braços abertos e fechados, o número de vezes que o animal passou pelo centro do labirinto (cruzamentos no quadrado central) e o tempo de permanência nos braços abertos, fechados e no centro do 
labirinto. O critério para se caracterizar a entrada e/ou a saída dos braços foi definido como a colocação das quatro patas nos braços e/ou no quadrado central (Rodgers et al., 1994). Ao término da sessão um, o animal foi transferido para sua gaiola, onde permaneceu por 5 minutos. Durante esse período, o labirinto foi limpo com uma solução de álcool a 10\%, para minimizar a interferência de odores eventualmente deixados pelo animal. A seguir, o mesmo animal foi submetido a uma segunda exposição ao labirinto idêntica à primeira (sessão dois).

\subsubsection{Treino de condicionamento clássico aversivo}

O aparelho utilizado no treino de condicionamento clássico aversivo (Figura 22) constitui de uma típica caixa de esquiva inibitória, a qual compreendeu dois compartimentos de acrílico de dimensões $30 \times 28 \times 40 \mathrm{~cm}$, conectados por uma portinhola do tipo "guilhotina" de $10 \times 10 \mathrm{~cm}$, distante $10 \mathrm{~cm}$ das paredes laterais. Um dos compartimentos tinha paredes brancas (compartimento $A$ ), enquanto $O$ outro compartimento possuía duas paredes pretas (paredes laterais) e duas paredes brancas com figuras geométricas pretas (paredes anterior e posterior; compartimento B). $\mathrm{O}$ assoalho consistia de barras de aço de $0,32 \mathrm{~cm}$ de diâmetro com distância de cerca de $1,5 \mathrm{~cm}$ entre si. As barras de aço do assoalho do compartimento B eram conectadas a um gerador de choque sem "scrambler". Às paredes do compartimento B foram instaladas três caixas de som, as quais, quando acionadas por computador, liberavam um som de $550 \mathrm{~Hz}$ e $80 \mathrm{~dB}$. 

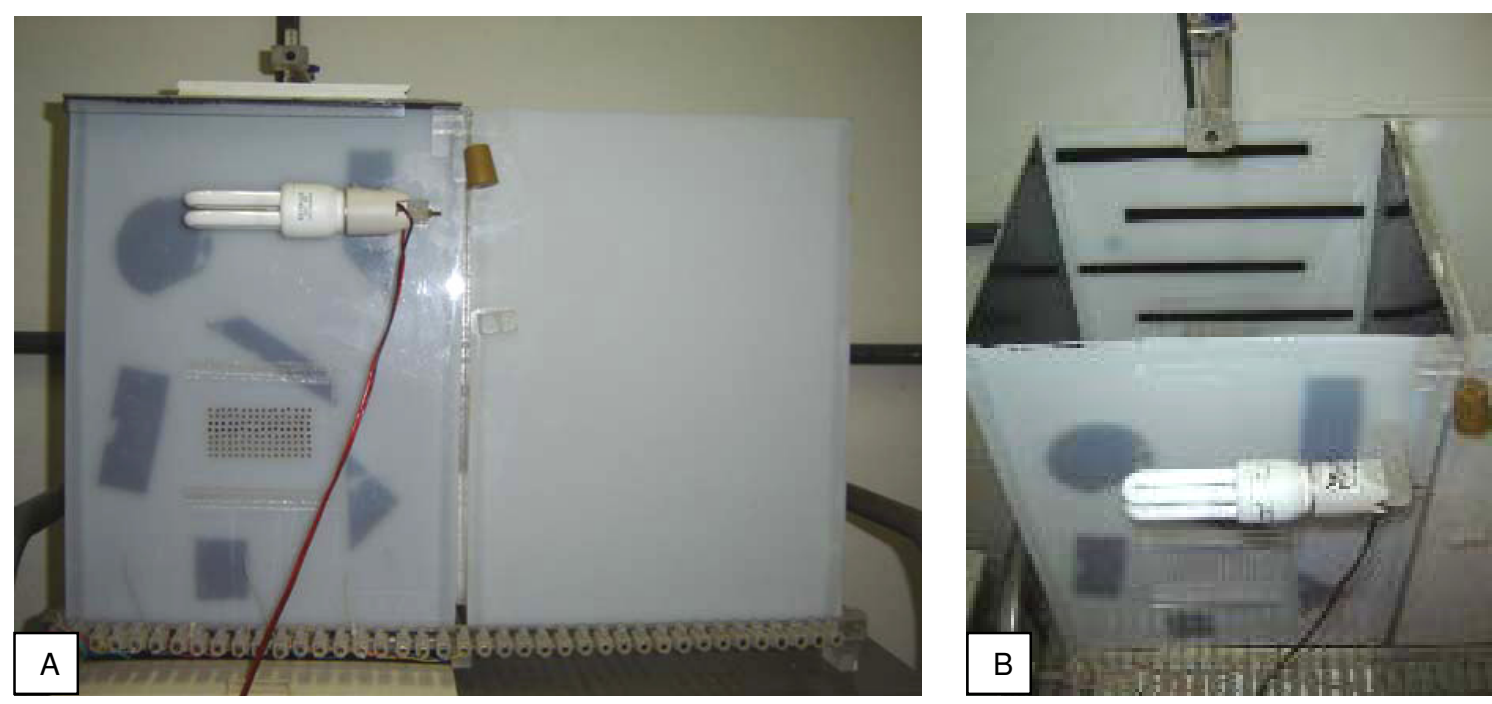

Figura 04. Fotografia do aparelho utilizado no treino da tarefa de condicionamento clássico aversivo e no teste de medo condicionado ao contexto. (A) Parte externa do aparelho. (B) Vista superior do aparelho.

O treino de condicionamento aversivo foi conduzido somente no compartimento B da caixa, que era fechado por uma tampa, onde se encontrava um orifício através do qual todo o procedimento foi filmado por uma câmera de vídeo ligada a um vídeo cassete e a uma televisão, sendo possível, desta maneira, a gravação do treinamento de cada animal.

Para o treinamento dos animais na situação de condicionamento clássico aversivo, os animais receberam pareamento de som com choque.

Cada sujeito (anóxia e controle) foi inicialmente retirado individualmente de sua gaiola no biotério, colocado em uma outra gaiola e transportado para a sala de experimentação. Em seguida, o animal era introduzido no compartimento $B$ do aparelho. Passados dois minutos, o animal recebia o primeiro pareamento somchoque, tendo o som duração de cinco segundos, e o choque sendo liberado durante o último segundo da apresentação do som (som: $5 \mathrm{~s}, 550 \mathrm{~Hz}, 80 \mathrm{~dB}$; choque: $1 \mathrm{~s}, 1 \mathrm{~mA}$ ). Foram administrados cinco pareamentos de som e choque, com intervalos de 30 segundos entre eles. Após o último pareamento de som e choque, aguardava-se 30 segundos para a retirada do animal do aparelho. Findo o treinamento, o animal era transportado de volta para a sua gaiola. $O$ treino na situação de condicionamento clássico aversivo tinha, portanto, duração total de quatro minutos e meio. 


\subsubsection{Teste de medo condicionado ao contexto}

O mesmo aparelho utilizado no treino de condicionamento clássico aversivo (Figura 22) foi utilizado no teste de medo condicionado ao contexto.

O procedimento de teste consistia em, inicialmente, transportar o animal individualmente da sua gaiola para a sala de experimentação. Em seguida, o animal era introduzido no compartimento B do aparelho, onde permanecia por um período de quatro minutos; nenhum estímulo sonoro nem tampouco o choque eram apresentados ao animal. Findo esse período, o animal era retirado do aparelho experimental e transportado de volta à sua gaiola. A sessão do teste foi filmada e gravada em fitas de vídeo.

A duração das respostas de congelamento foi medida durante o teste de condicionamento aversivo ao contexto, e analisada em quatro blocos de um minuto.

\subsubsection{Teste de medo condicionado ao som}

O teste de medo condicionado ao som foi realizado em uma sala em uma sala experimental diferente da sala onde foram realizados o treino e o teste de condicionamento ao contexto.

O aparelho do teste (Figura 23) também foi diferente, consistindo de um cilindro de acrílico cinza, de $40 \mathrm{~cm}$ de altura e $37 \mathrm{~cm}$ de diâmetro. Diferentemente do aparelho de treino o assoalho não possuía grades metálicas, mas era de acrílico preto. Três caixas de som foram conectadas à parede do aparelho, de modo que quando acionadas por computador, produziam um som idêntico (550 $\mathrm{Hz}, 80 \mathrm{~dB}, 5 \mathrm{~s}$ ) ao empregado durante o treino de condicionamento aversivo. 

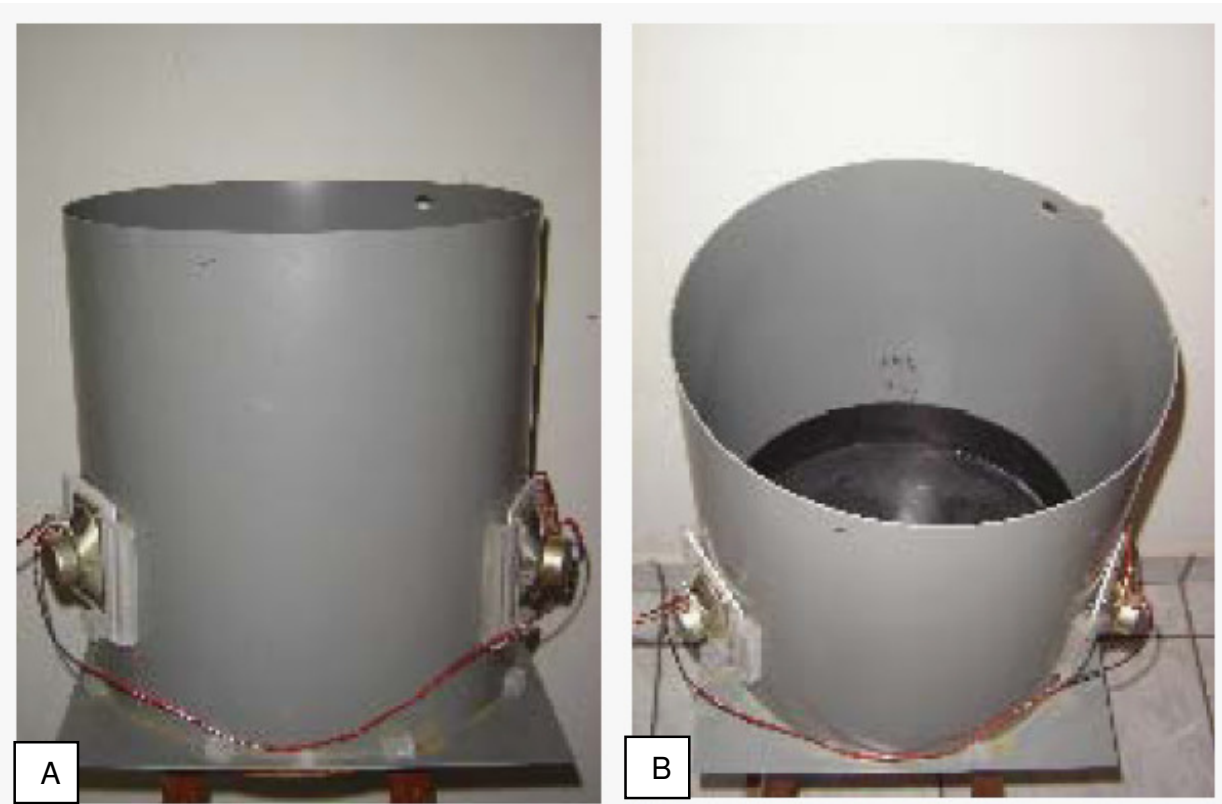

Figura 05. Fotografia do aparelho utilizado no teste de medo condicionado ao som. (A) Parte externa do aparelho. (B) Vista superior do aparelho.

O procedimento de teste consistia em, inicialmente, transportar o animal individualmente da sua gaiola para a sala de experimentação. Em seguida o animal era introduzido ao aparelho, onde, após três minutos, iniciava-se cinco apresentações do som, cada qual por um período de cinco segundos, com intervalos de 30 segundos entre elas. O animal permanecia no aparelho até o término do oitavo minuto, quando então, era retirado e transportado de volta à gaiola. Em nenhum momento o choque era apresentado ao animal. A sessão do teste foi filmada e gravada em fitas de vídeo.

A duração das respostas de congelamento foi medida durante o teste de condicionamento aversivo ao som, e analisada posteriormente em oito blocos de um minuto cada. 
Para realizar a análise estatística nos testes envolvendo a memória de referência espacial, memória operacional e plataforma visível, foi utilizada uma Análise de Variância para Medidas Repetidas (ANOVA) separada para cada um dos parâmetros mensurados, incluindo latência, comprimento do trajeto e velocidade do nado, tendo grupos (anóxia versus controle) como fator entre sujeitos, e tentativas (memória de referência espacial - primeira à quarta, memória operacional e plataforma visível - primeira a terceira), e dias (memória de referência - de um a dez, memória operacional ITI 10 - de um a seis, ITI trinta e zero - de um a quatro e plataforma visível - de um a três) como fatores intrasujeitos. Quando a ANOVA indicou a existência de diferenças significantes, realizou-se um teste post hoc de comparações múltiplas de Duncan para identificar a origem da diferença.

No teste do labirinto em cruz elevado, a partir dos escores mensurados, calculou-se a percentagem de entrada nos braços abertos (o número de entradas nos braços abertos dividido pela soma do número de entradas nos braços abertos e número de entrada nos braços fechados por 100) e a porcentagem de tempo nos braços abertos (o tempo de permanência nos braços abertos dividido pela soma do tempo de permanência nos braços abertos, tempo de permanência nos braços fechados e tempo de permanência no quadrado central, multiplicado por 100).

A ANOVA permitiu comparar o desempenho dos animais dos grupos anóxia e controle, tomados como fator entre-sujeitos, nas duas sessões de teste, tomadas como fator intra-sujeitos. Foram realizadas ANOVAs independentes para cada um dos parâmetros comportamentais considerados relevantes, incluindo a porcentagem de entradas nos braços abertos, a percentagem de tempo nos braços abertos, o número de entradas nos braços fechados, o tempo de permanência no quadrado central e o número de cruzamentos no quadrado central. 
Os dados comportamentais referentes aos testes de medo condicionado ao som e ao contexto foram analisados estatisticamente através de uma Análise de Variância (ANOVA) para medidas repetidas. A ANOVA permitiu comparar o desempenho dos animais dos grupos anóxia e controle, tomados como fator entresujeitos, e um fator intra-sujeitos, que consistiu nos blocos de tempo nos qual o teste foi dividido (quatro blocos de um minuto cada). A porcentagem de tempo em de congelamento exibido pelos animais durante o teste foi tomada como variável dependente.

Os dados de todos os testes foram analisados por meio do pacote estatístico SAS (SAS Institute Inc.) e os gráficos construídos com auxílio do programa Sigma Plot (versão 9.0) e do programa Graph Pad Prism 5.00. 
Os resultados evidenciaram diferenças comportamentais entre os grupos dos animais anóxia e controle, nos testes envolvendo a memória de referência espacial, memória operacional com diferentes intervalos entre as tentativas e plataforma visível, sugerindo que a anóxia interferiu na aquisição e desempenho da tarefa de navegação espacial no labirinto aquático de Morris. No teste do labirinto em cruz elevado os animais anóxias mostraram-se menos ansiosos, tendo permanecido menor tempo em congelamento no teste do medo condicionado ao contexto, porém não ao som. 


\subsection{Memória de referência espacial}

No teste envolvendo a memória de referência espacial, os resultados evidenciaram que houve melhora de desempenho tanto dos animais anóxia como dos animais controle ao longo dos 10 dias de teste, indicando que houve aquisição da tarefa de navegação espacial, porém, observou-se que os animais anóxia demonstraram desempenho inferior quando comparado aos animais controle, conforme ilustrado na figura 6. Verificaram-se diferenças significantes em relação aos grupos anóxia e controle $(P=0.0059)$, indicando que a anóxia neonatal, como produzida no presente estudo, gerou prejuízo no desempenho dos animais anóxia. Observou-se também, que houve melhora de desempenho dos animais de ambos os grupos, no decorrer das tentativas do mesmo dia e ao longo dos dias de testes, evidenciados pelas diferenças significantes em relação aos fatores dia $(P<$ $0.0001)$, tentativa $(P<0.0001)$ e também em relação à interação dia/tentativa $(P<$ $0.0001)$.

\section{MEMÓRIA DE REFERÊNCIA ESPACIAL}

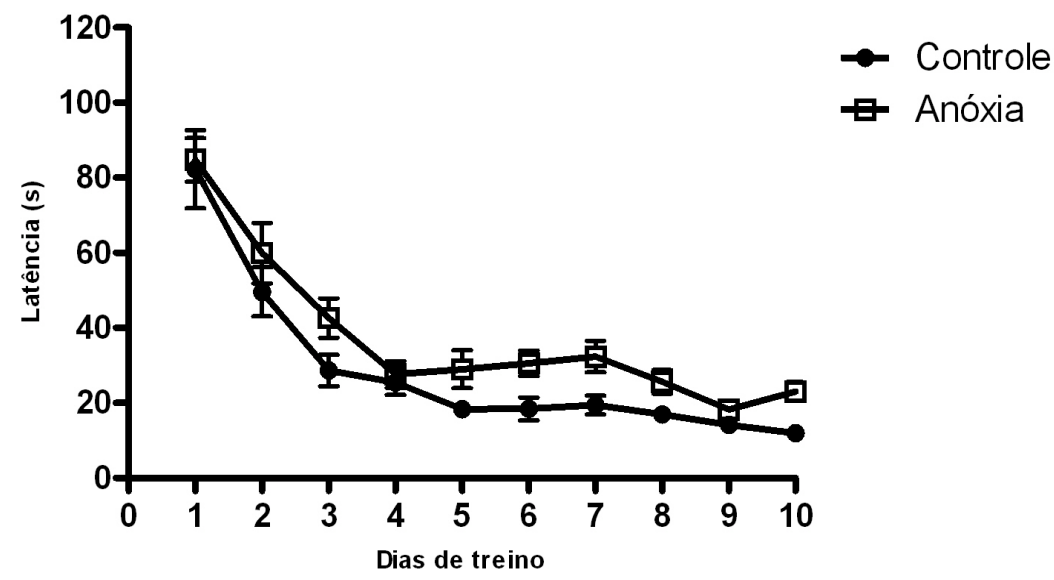

Figura 6. Latência dos animais dos grupos controle $(n=12)$ e anóxia $(n=13)$ ao longo dos dias de treinamento no teste de memória de referência espacial no labirinto aquático de Morris. Os valores indicam a Média ( \pm E.P.M.) de 4 tentativas a cada dia. 


\subsection{Memória operacional (dez, trinta e zero)}

Nos testes envolvendo a memória operacional com intervalos entre as tentativas de dez, trinta e zero, os resultados evidenciaram que houve melhora de desempenho tanto dos animais anóxia como dos animais controle ao longo das tentativas de cada dia de teste, porém a melhora nos animais controle ocorreu em um espaço de tempo menor, evidenciado desde o primeiro dia. Observou-se que os animais anóxia necessitaram de mais dias de teste, para atingirem desempenho próximo aos encontrados nos animais do outro grupo, conforme ilustrado nas figuras 7,8 e 9.

Os resultados demonstraram diferença significante quanto ao fator grupo, nos três intervalos entre as tentativas; ITI 10 ( $P=0.0004)$, ITI $30(P=0.0418)$ e ITI $0(P=0.0095)$, indicando que a anóxia, como produzida no presente estudo, gerou prejuízo no desempenho dos animais anóxia, no teste da memória operacional. No que diz respeito ao fator tentativa, o mesmo valor de significância $(P<0.0001)$ foi revelado nos diferentes intervalos entre as tentativas (dez, trinta e zero) minutos.

Com relação à interação dos fatores tentativa/grupo, ITI 10, observou-se diferença significante entre grupos principalmente na tentativa dois $(P=0,0200)$, tendo sido esta diferença mais evidente, nos dias um, cinco e seis. Quando o ITI foi de 0 minuto, observou-se diferença entre grupos próximo da significância $(P=$ 0.0708), indicando que houve melhora de desempenho de ambos os grupos, quanto às tentativas, do mesmo dia de teste, porém esta melhora, menos evidente nos animais anóxia. Verificou-se ausência de significância quando o ITI foi de 30 minutos $(P=0,5293)$, indicando que houve melhora no desempenho dos animais de ambos os grupos, quanto às tentativas do mesmo dia de teste. 
MEMÓRIA OPERACIONAL - LATÊNCIA - ITI 10

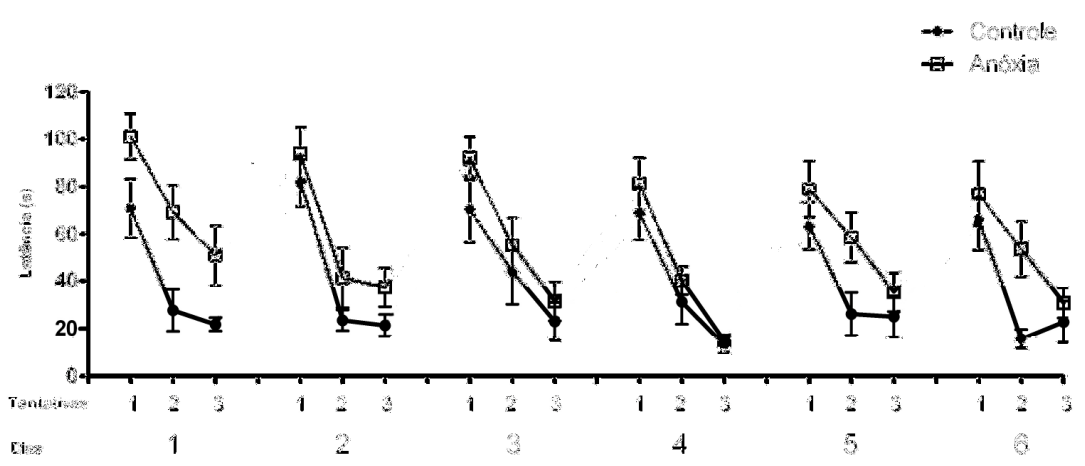

Figura 7. Latência dos animais dos grupos anóxia $(n=13)$ e controle $(n=12)$ ao longo dos seis dias de treinamento no teste de memória operacional no labirinto aquático de Morris. Os valores indicam a Média ( \pm E.P.M.) das tentativas dos grupos anóxia e controle ao longo dos dias.

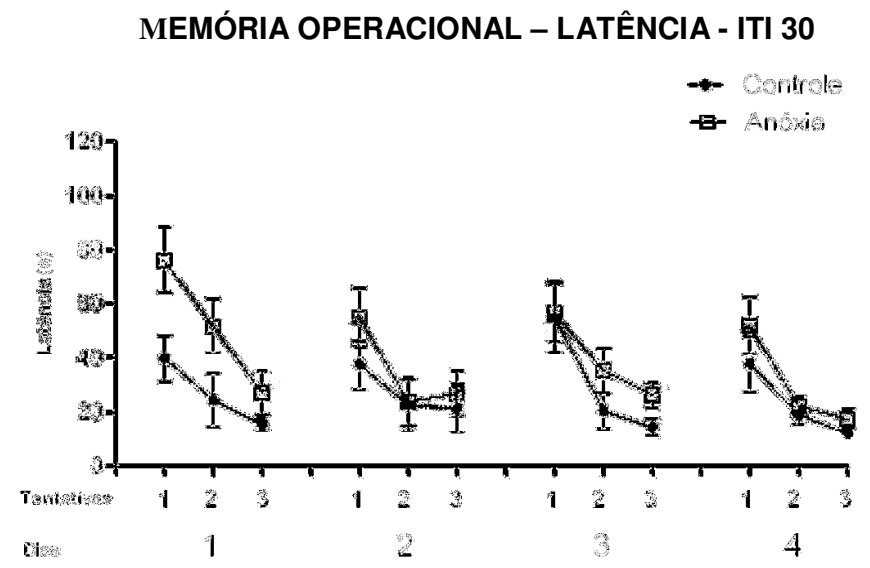

Figura 8. Latência dos animais dos grupos anóxia e controle ao longo dos quatro dias de treinamento no teste de memória operacional no labirinto aquático de Morris. Os valores indicam a Média $( \pm$ E.P.M.) das tentativas dos grupos anóxia e controle ao longo dos dias.

MEMÓRIA OPERACIONAL - LATÊNCIA - ITI 0

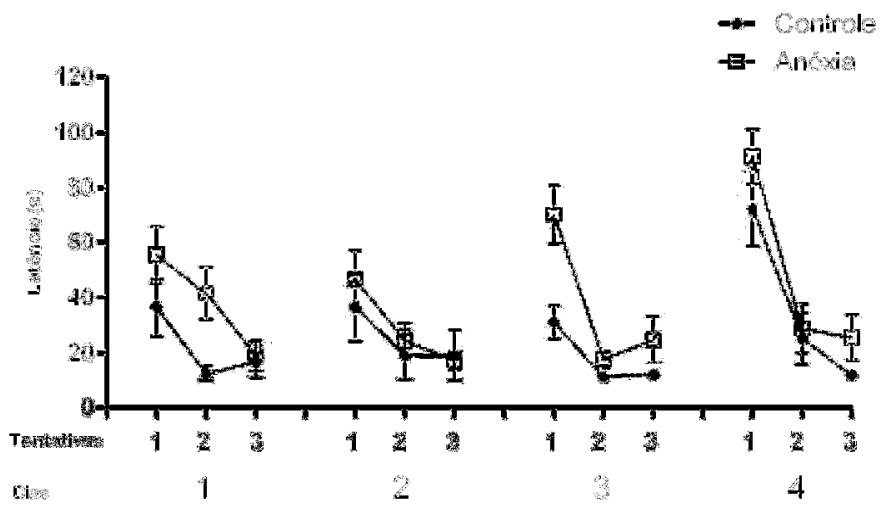

Figura 9. Latência dos animais dos grupos anóxia e controle ao longo dos quatro dias de treinamento no teste de memória operacional no labirinto aquático de Morris. Os valores indicam a Média ( \pm E.P.M.) das tentativas dos grupos anóxia e controle ao longo dos dias. 
Nos testes envolvendo a memória operacional com intervalos entre as tentativas de dez, trinta e zero, os resultados evidenciaram diminuição do comprimento do trajeto dos animais de ambos os grupos, ao longo das tentativas de cada dia de teste, sendo esta diferença, menos evidente nos animais anóxia, estes, percorreram trajeto maior quando comparado aos animais controle, e necessitaram de mais dias de testes, para atingirem desempenho próximo aos encontrados nos animais do outro grupo, conforme ilustrado nas figuras 10, $11 \mathrm{e}$ 12. Revelou-se também que os animais de ambos os grupos diminuíram o comprimento do trajeto à medida em passavam pelas tarefas, ou seja, conseguiram valer-se das experiências prévias para melhorarem seu desempenho.

Os resultados revelaram diferença significante em relação ao fator grupo, nos três intervalos entre as tentativas; ITI $10(P=0,0264)$, ITI $0(P=0,0344)$, porém ausência de diferença significante quando o ITI foi de 30 minutos $(P=$ 0,1407). Com relação ao fator tentativa, a mesma diferença significante $(P<$ $0,0001)$ foi revelada nos diferentes intervalos entre as tentativas (dez, trinta e zero) minutos.

Com relação à interação tentativa/grupo, ITI 10, revelou-se diferença significante na tentativa dois $(P=0,0318)$, tendo sido esta diferença mais evidente nos dias um e cinco. Porém observou-se ausência de diferença significante quanto ao mesmo parâmetro, no ITI $30(P=0,9623)$ e ITI $0 \quad(P=0,6786)$. 
MEMÓRIA OPERACIONAL - COMPRIMENTO DO TRAJETO - ITI 10

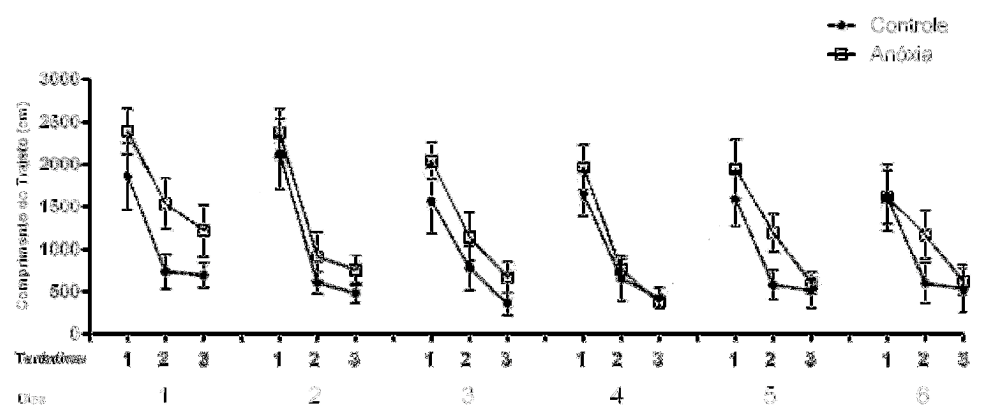

Figura 10.Comprimento do trajeto dos animais dos grupos anóxia $(n=13)$ e controle $(n=12)$ ao longo dos seis dias de treinamento no teste de memória operacional no labirinto aquático de Morris. Os valores indicam a Média ( \pm E.P.M.) das tentativas dos grupos anóxia e controle ao longo dos dias.

MEMÓRIA OPERACIONAL- COMPRIMENTO DO TRAJETO - ITI 30

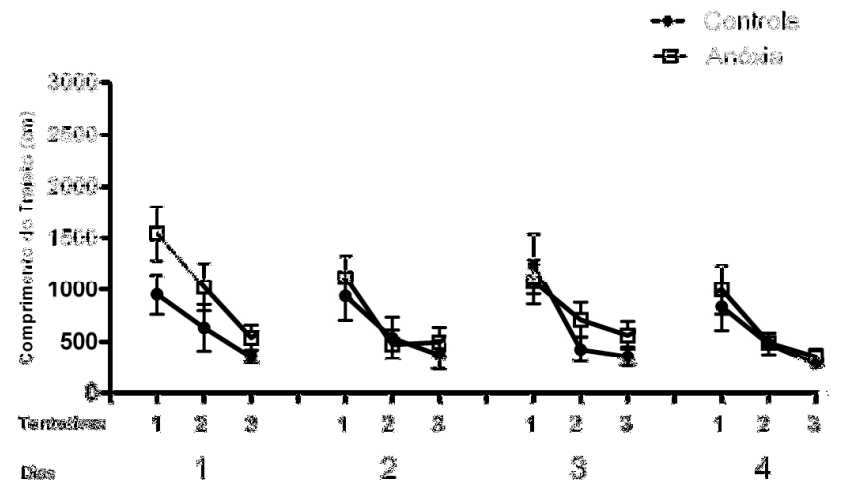

Figura 11. Comprimento do trajeto dos animais dos grupos anóxia $(n=13)$ e controle $(n=12)$ ao longo dos quatro dias de treinamento no teste de memória operacional no labirinto aquático de Morris. Os valores indicam a Média ( \pm E.P.M.) das tentativas dos grupos anóxia e controle ao longo dos dias.

MEMÓRIA OPERACIONAL - COMPRIMENTO DO TRAJETO -ITI 0

$$
\text { E Cnota }
$$

$\rightarrow$ Conto

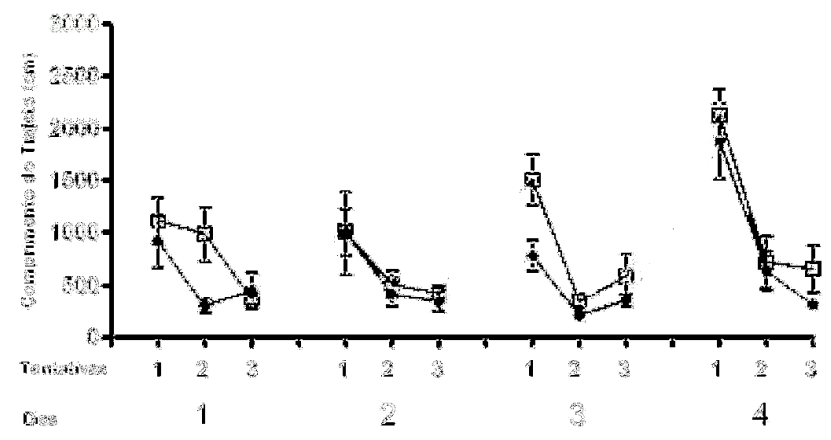

Figura 12. Comprimento do trajeto dos animais dos grupos anóxia $(n=13)$ e controle $(n=12)$ ao longo dos quatro dias de treinamento no teste de memória operacional no labirinto aquático de Morris. Os valores indicam a Média ( \pm E.P.M.) das tentativas dos grupos anóxia e controle ao longo dos dias. 
Nos testes envolvendo a memória operacional com intervalos entre as tentativas de dez, trinta e zero, os resultados evidenciaram que houve variações na velocidade do nado de ambos os grupos em relação às tentativas do mesmo dia de teste e que os animais anóxia, apresentaram velocidade do nado inferior quando comparado aos animais controle, conforme ilustrado nas figuras 13, 14 e 15.

Os resultados revelaram diferença significante em relação ao fator grupo, nos três intervalos entre as tentativas; ITI $10(P=0,0021)$, ITI $30(P=0,0170)$ e ITI $0(P=0,0129)$, indicando que a anóxia neonatal, como produzida no presente estudo, gerou prejuízo na velocidade do nado dos animais do grupo anóxia.

Observou-se diferença significante em relação ao fator dia quando os intervalos entre as tentativas foi de $10(P=0,0003)$ e $0(P=0.0019)$, indicando que houve variação na velocidade do nado entre os diferentes dias de testes, porém verificou-se ausência de significância quando o ITI foi de $30(P=0,5347)$.

Demonstrou diferença significante em relação à interação dia/tentativa ITI 0 e $10(P=<0,0001)$ e ITI $30(P=0,0003)$ e quanto a interação dia/tentativa/grupo quando o ITI foi de $0(P=0,0400)$ e ITI $30(P=0,0126)$, indicando que houve variação na velocidade do nado entre os diferentes grupos, dias e tentativas de testes e que os animais anóxia apresentaram velocidade do nado inferior que os animais controle, porém verificou-se ausência de diferença significante quando o ITI foi de $10(0,3557)$. 
MEMÓRIA OPERACIONAL - VELOCIDADE - ITI 10

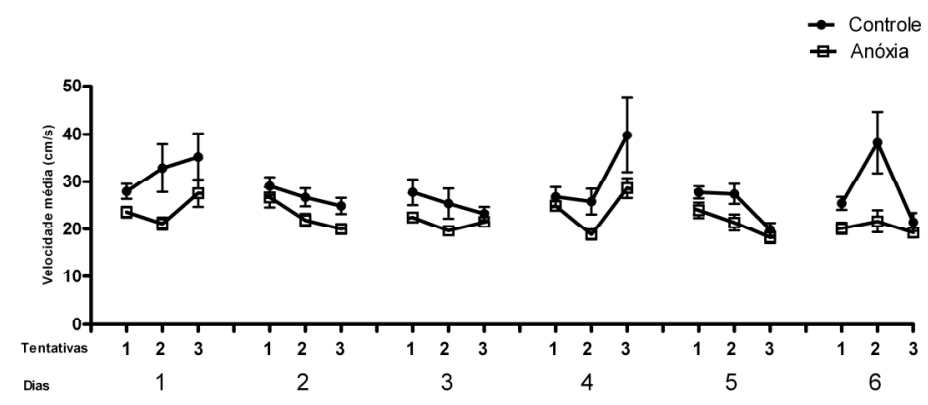

Figura 13. Velocidade do nado dos animais dos grupos anóxia $(n=13)$ e controle $(n=12)$ ao longo dos seis dias de treinamento no teste de memória operacional no labirinto aquático de Morris. Os valores indicam a Média ( \pm E.P.M.) das tentativas dos grupos anóxia e controle dos dias.

MEMÓRIA OPERACIONAL -VELOCIDADE- ITI 30

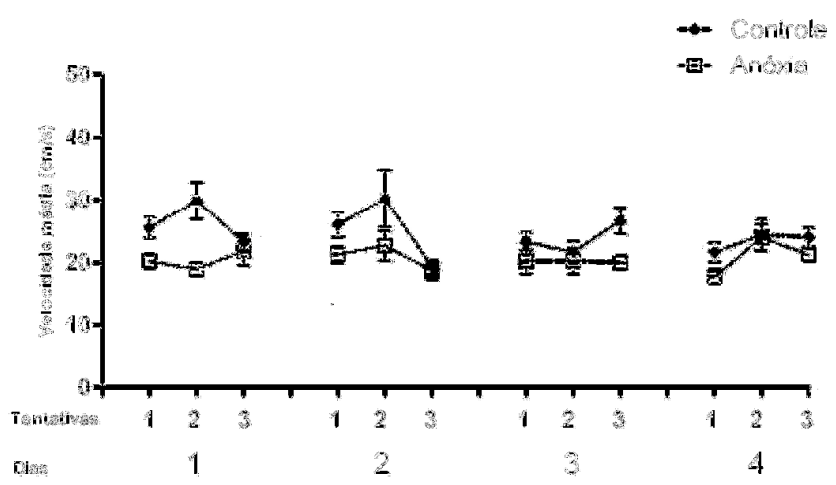

Figura 14. Velocidade do nado dos animais dos grupos anóxia $(n=13)$ e controle $(n=12)$ ao longo dos quatro dias de treinamento no teste de memória operacional no labirinto aquático de Morris Os valores indicam a Média ( \pm E.P.M.) das tentativas dos grupos anóxia e controle ao longo dos dias.

MEMÓRIA OPERACIONAL - VELOCIDADE - ITI 0

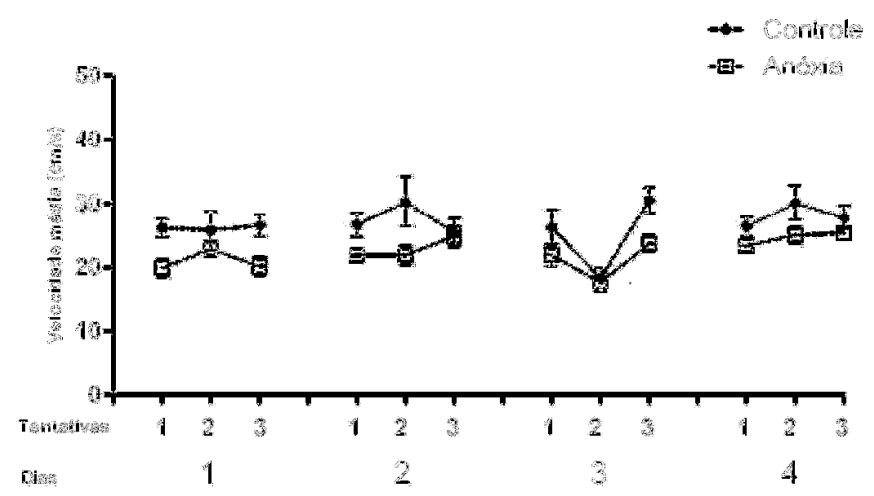

Figura 15. Velocidade do nado dos animais dos grupos anóxia $(n=13)$ e controle $(n=12)$ ao longo dos quatro dias de treinamento no teste de mem ória operacional no labirinto aquático de Morris. Os valores indicam a Média ( \pm E.P.M.) das tentativas dos grupos anóxia e controle ao longo dos dias. 


\subsection{Plataforma visível}

No teste envolvendo a plataforma visível, os resultados evidenciaram que houve variação de desempenho dos animais de ambos os grupos quanto às tentativas do mesmo dia de teste e que os animais anóxia demonstraram desempenho inferior, expresso pela maior latência, quando comparado aos animais controle, conforme ilustra a figura 16.

Os resultados revelaram diferença significante em relação ao fator grupo ( $P$ = 0,0305), indicando que a anóxia, gerou prejuízo no desempenho no teste com a plataforma visível. Observou-se existência de diferença significante em relação ao fator tentativa $(P=0.0212)$ e quanto à interação dia/tentativa $(P=0.0354)$, indicando que houve variação no desempenho dos animais quanto às tentativas do mesmo dia de teste, bem como variação entre os dias de testes. Não se observou diferença significante em relação à interação tentativa/grupo $(P=$ $0.6544)$.

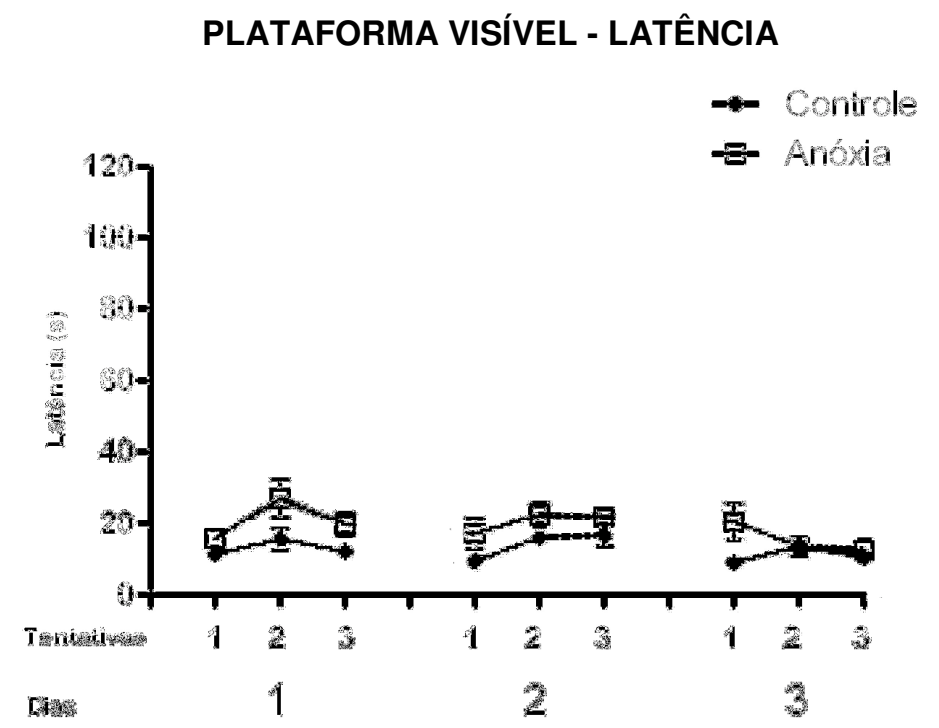

Figura 16. Latências dos animais dos grupos anóxia $(n=13)$ e controle $(n=12)$ ao longo dos três dias de teste com plataforma visível no labirinto aquático de Morris. Os valores indicam a Média ( \pm E.P.M.) das tentativas dos grupos anóxia e controle ao longo dos dias. 
No teste envolvendo a plataforma visível, os resultados evidenciaram que houve variação quanto ao comprimento do trajeto, tanto dos animais anóxia como dos animais controle ao longo das tentativas de cada dia de teste, bem como entre os dias de testes, porém ausência de significância entre os grupos em relação ao comprimento do trajeto, conforme figura 17. Observou-se diferença significante em relação ao fator tentativa $(P=0.0050)$, porém ausência de diferenças significantes em relação aos fatores grupo $(P=0,1907)$ e tentativa/grupo $(P=0.6320)$.

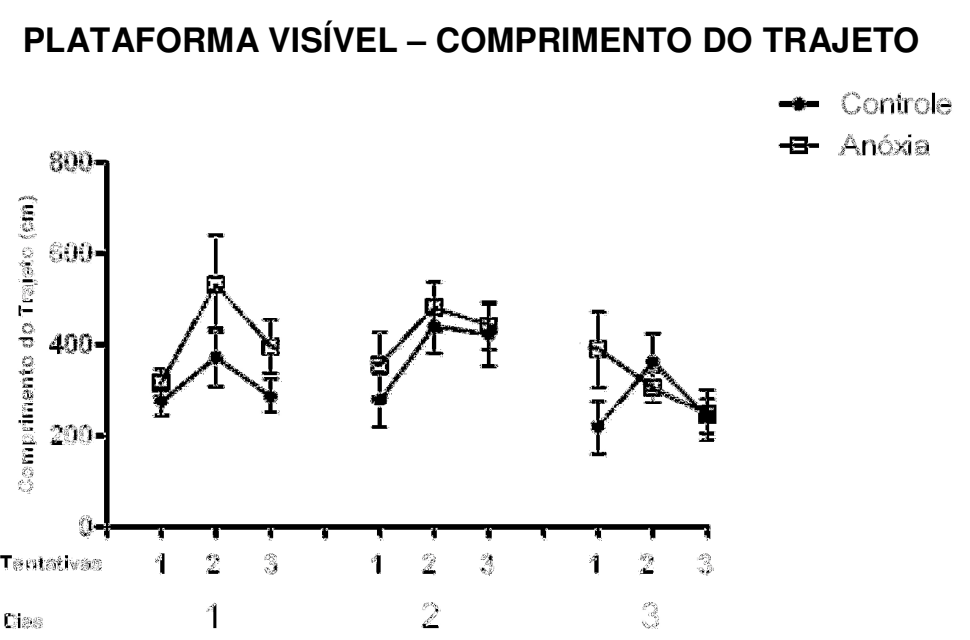

Figura 17. Comprimentos dos trajetos dos animais dos grupos anóxia $(n=13)$ e controle $(n=12)$ ao longo dos três dias de teste com plataforma visível no labirinto aquático de Morris. Os valores indicam a Média ( \pm E.P.M.) das tentativas dos grupos anóxia e controle ao longo dos dias. 
No teste envolvendo a plataforma visível, os resultados evidenciaram que houve variação de velocidade do nado entre as tentativas do mesmo dia de teste e que os animais anóxia apresentaram velocidade do nado inferior quando comparado aos animais controle, conforme ilustra figura 18.

Observou-se diferença significante em relação ao fator grupo $(P=0.0023)$ e em relação ao fator tentativa $(P=0.0036)$. Revelou ausência de diferença significante em relação à interação dos fatores tentativa/grupo $(P=0,4972)$.

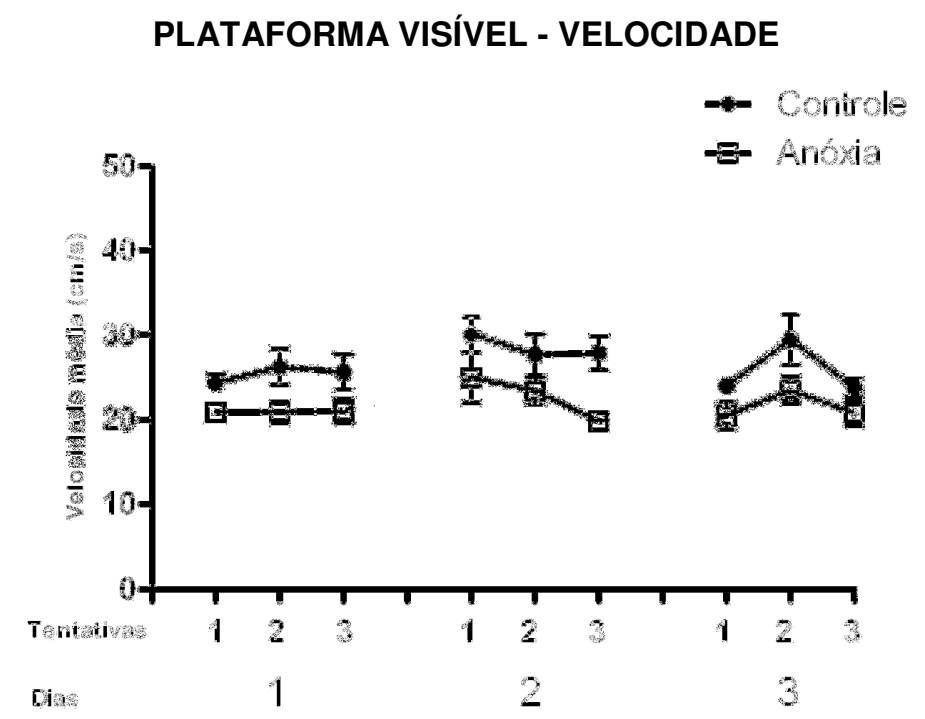

Figura 18. Velocidade do nado dos animais dos grupos anóxia anóxia $(n=13)$ e controle $(n=12)$ ao longo dos três dias de teste com plataforma visível no labirinto aquático de Morris. Os valores indicam a Média ( \pm E.P.M.) das tentativas dos grupos anóxia e controle ao longo dos dias. 


\subsection{Labirinto em cruz elevado}

No teste do labirinto em cruz elevado, os resultados evidenciaram que os animais anóxia entraram mais vezes nos braços abertos na primeira sessão, quando comparado aos animais controle. Na segunda sessão, a porcentagem de entrada dos animais anóxia nos braços abertos, é menor do que a observada na primeira sessão, sendo esta diferença estatisticamente significativa, não revelada nos animais controle, conforme ilustra a figura 19. Desta forma, os resultados revelaram existência de efeito significante em relação ao fator grupo na primeira sessão ( $P=0.001)$, ou seja, houve maior número de entrada dos animais anóxia nos braços abertos quando comparado ao outro grupo e também observou-se efeito significante na porcentagem de entradas dos animais experimentais na segunda sessão quando comparado a sessão anterior $(P=0.003)$, porém esta diferença significativa não é observada nos animais controle.

\section{PORCENTAGEM DE ENTRADAS NOS BRAÇOS ABERTOS}

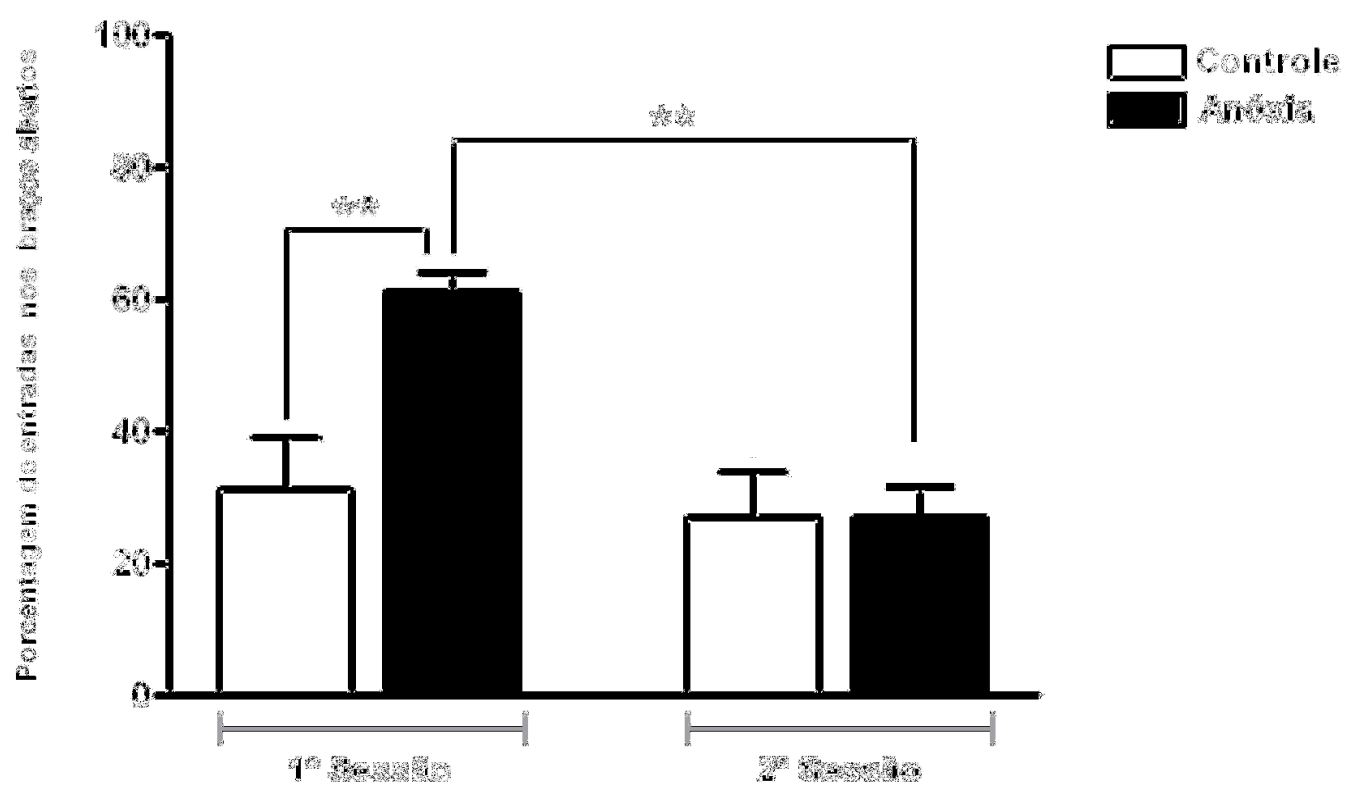

Figura 19. Porcentagem de entrada nos braços abertos dos animais dos grupos anóxia $(n=13)$ e controle $(n=12)$ na primeira e segunda sessão de teste no labirinto em cruz elevado. Os valores indicam a Média ( \pm E.P.M.) dos grupos anóxia e controle. ${ }^{* *}(P=0.001){ }^{* *}(P=0.003)$ 
Similarmente, os resultados evidenciaram que os animais anóxia permaneceram maior porcentagem de tempo nos braços abertos nas duas sessões, quando comparado aos animais controle, conforme ilustra a figura 20. Os resultados revelaram existência de diferença entre grupos, significante na sessão um $(P=0.035)$, ou seja, os animais experimentais permaneceram maior porcentagem de tempo nos braços abertos quando comparado ao outro grupo. Observou-se também que, apesar dos dois grupos ter permanecido menor porcentagem de tempo nos braços abertos, houve apenas existência de diferença significante entre sessões, nos animais anóxia $(P=0.001)$.

PORCENTAGEM DE TEMPO NOS BRAÇOS ABERTOS

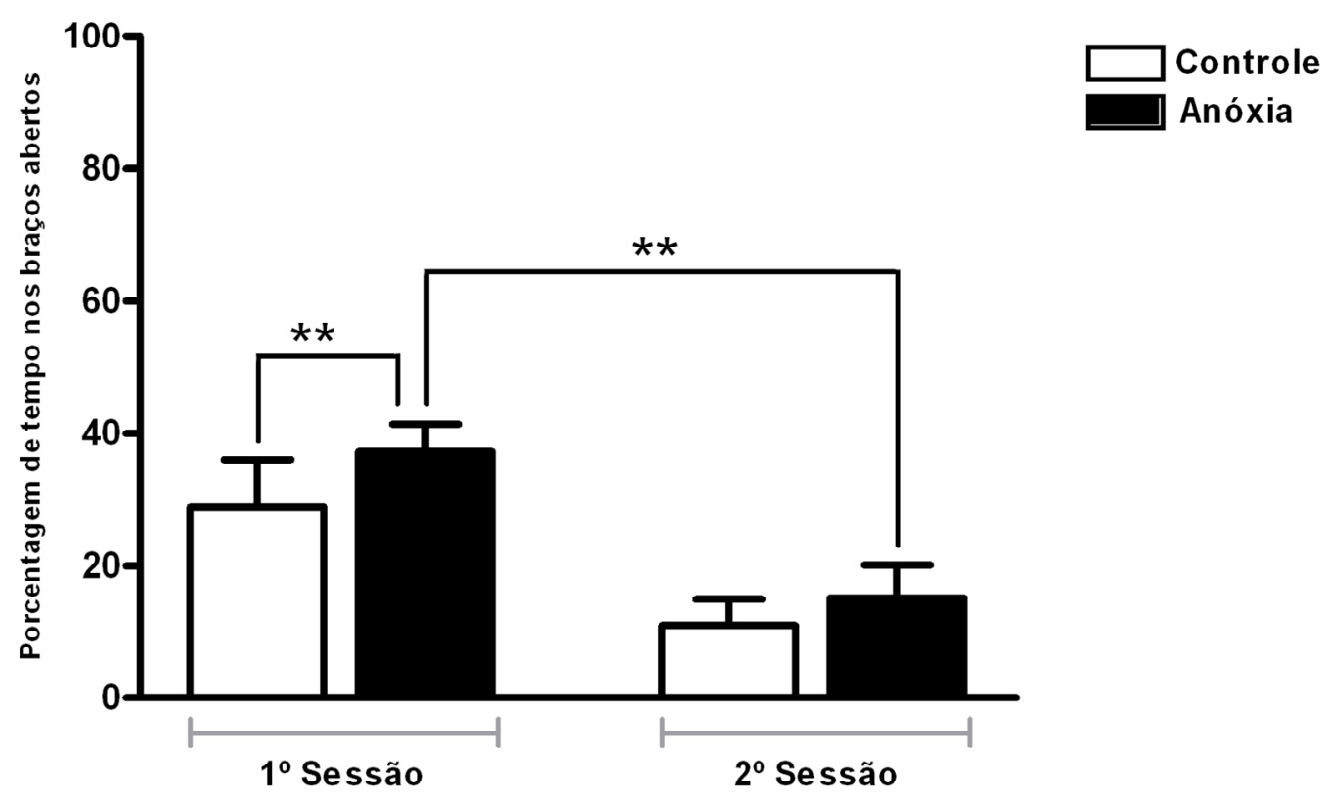

Figura 20. Porcentagem de tempo nos braços abertos dos animais anóxia $(n=13)$ e controle $(n=12)$ na primeira e segunda sessão de teste no labirinto em cruz elevado. Os valores indicam a Média ( \pm E.P.M.) dos grupos anóxia e controle nas sessões um e dois. ${ }^{* *}(P=0.035){ }^{* *}(P=0.001)$ 
Em relação ao número de entradas nos braços fechados, observou-se que na primeira sessão, os animais controle entraram maior número de vezes nos braços fechados quando comparado aos animais anóxia, desta forma, revelou que os animais experimentais apresentaram menor atividade locomotora na sessão um, quando comparado comparada ao outro grupo. Por outro lado, na segunda sessão, o número de entrada dos animais de ambos os grupos se equiparam, conforme ilustra a figura 21.

Os resultados evidenciaram existência de diferença significante entre grupos $(P=0.011)$, na primeira sessão, tendo os animais anóxia entrado menor número de vezes nos braços fechados quando comparado ao outro grupo. Observou-se diferença significante em relação ao fator sessão, no grupo anóxia ( $P$ = 0.003), a percentagem de entrada dos animais anóxia, na segunda sessão é maior do que a observada na primeira sessão, porém esta diferença não é observada nos animais controle.

\section{NÚMERO DE ENTRADAS NOS BRAÇOS FECHADOS}

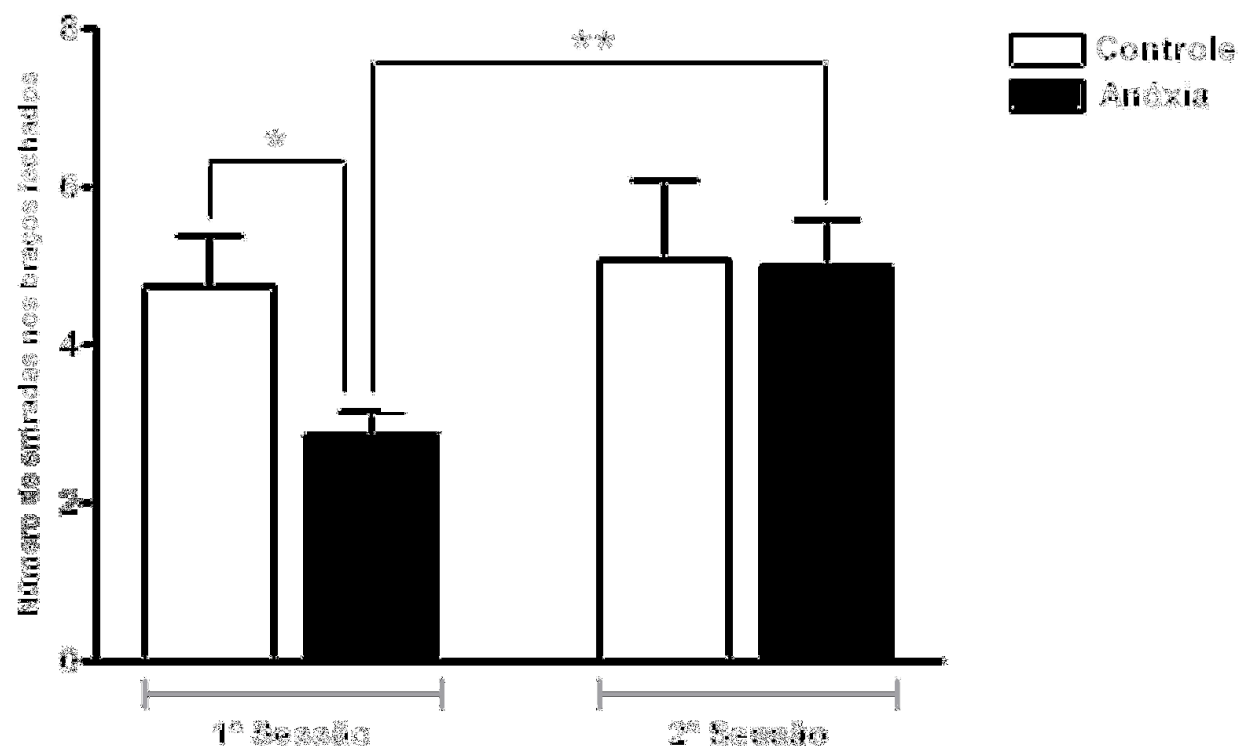

Figura 21. Número de entrada nos braços fechados dos animais dos grupos anóxia $(n=13)$ e controle $(n=12)$ na primeira e segunda sessão de teste no labirinto em cruz elevado. Os valores indicam a Média ( \pm E.P.M.) dos grupos anóxia e controle nas sessões um e dois. ${ }^{*}(P=0.011){ }^{* \star}(P=0.003)$ 
Quanto ao tempo de permanência no quadrado central, os resultados evidenciaram que os animais anóxia, permaneceram maior tempo no quadrado central, quando comparado aos animais controle apenas na primeira sessão, conforme ilustrado na figura 22. Os resultados revelaram diferença significante em relação aos grupos, na primeira sessão $(P=0.044)$, foi observado que os animais experimentais permaneceram maior tempo no quadrado central, quando comparado aos animais do outro grupo, porém ausência de diferença significante com relação ao mesmo fator na segunda sessão ( $P=0,906)$. Revelou-se ausência de diferença significante intra-sujeitos quando comparado às duas sessões; animais anóxia $(P=0,235)$ e animais controle $(P=0,591)$, bem como quanto à interação entre sessão e grupo $(P=0,150$ e $P=0,558)$.

TEMPO DE PERMANÊNCIA NO QUADRANTE CENTRAL

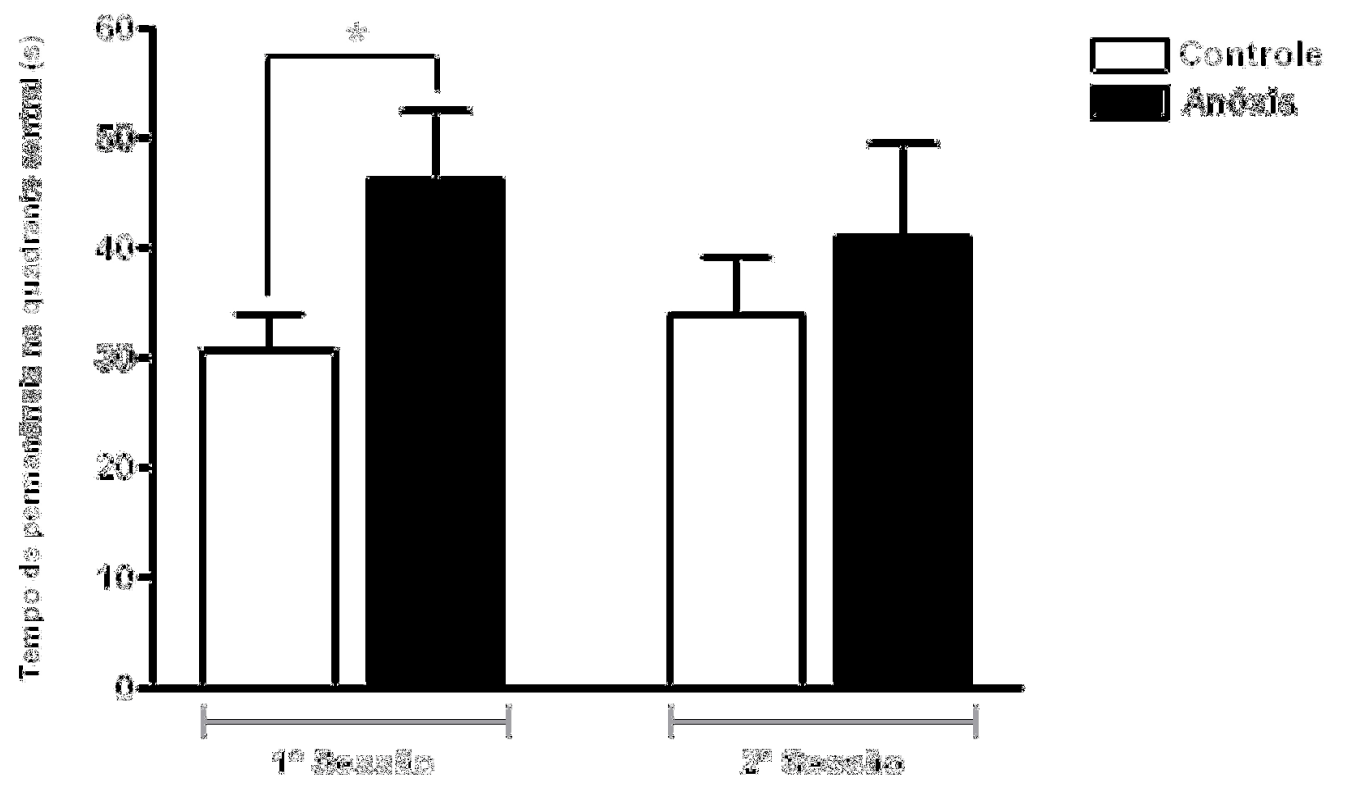

Figura 22. Tempo de permanência no quadrado central dos animais dos grupos anóxia $(n=13)$ e controle $(n=12)$ na primeira e segunda sessão de teste no labirinto em cruz elevado. Os valores indicam a Média ( \pm E.P.M.) dos grupos anóxia e controle nas sessões um e dois. ${ }^{*}(P=0.044)$ 
Por fim, em relação ao número de cruzamentos no quadrado central, os resultados não evidenciaram diferenças significativas em relação aos parâmetros avaliados, conforme ilustra a figura 23. Desta forma, não se observou quaisquer diferenças significante entre as sessões $(P=0,842$ e $P=$ $0,700)$, grupos na primeira sessão $(P=0,969)$, na segunda sessão $(P=0,867)$ ou interações significantes em relação a esses fatores $(P=0,664$ e $P=0,870)$.

\section{NÚMERO DE CRUZAMENTOS NO QUADRADO CENTRAL}

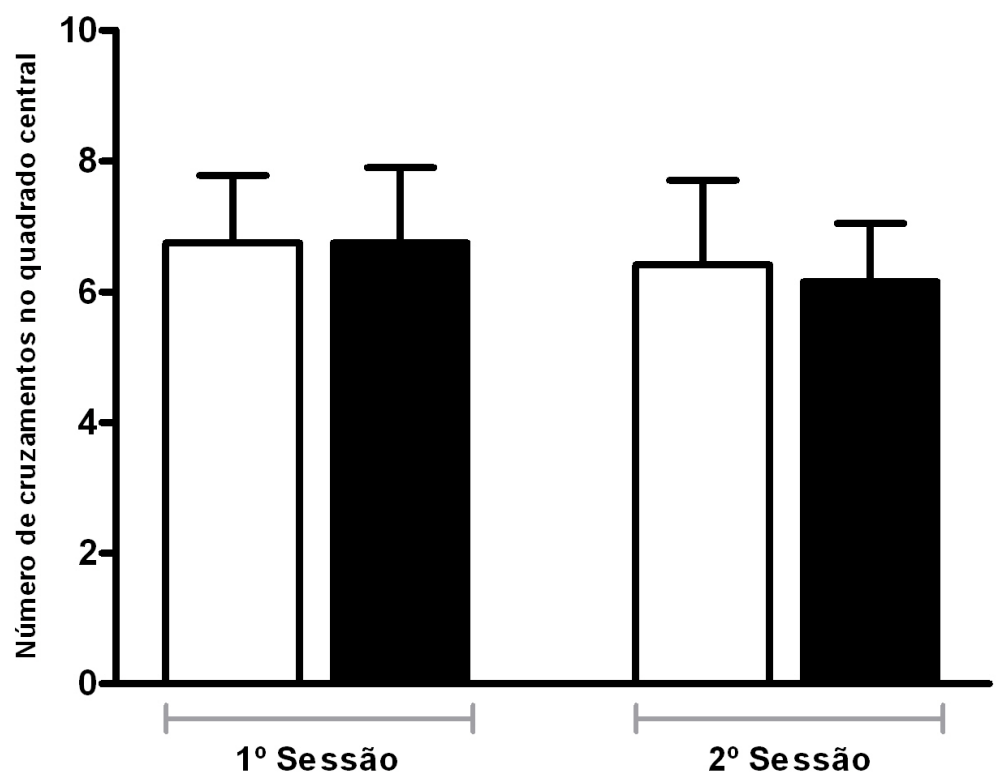

Figura 23. Número de cruzamentos no quadrado central dos animais dos grupos anóxia $(n=13)$ e controle $(n=12)$ na primeira e segunda sessão de teste no abirinto em cruz elevado. Os valores indicam a Média ( \pm E.P.M.) dos grupos anóxia e controle nas sessões um e dois. 


\subsection{Medo condicionado ao contexto e medo condicionado ao som}

No teste de medo condicionado ao contexto, os resultados não evidenciaram diferenças significantes entre os grupos anóxia e controle no tempo em congelamento durante o teste, conforme ilustra a figura 24. Desta forma revelou inexistência de efeito significante em relação ao fator grupo ( $P=0,189)$.

\section{TESTE DE MEDO CONDICIONAMENTO CONTEXTO}

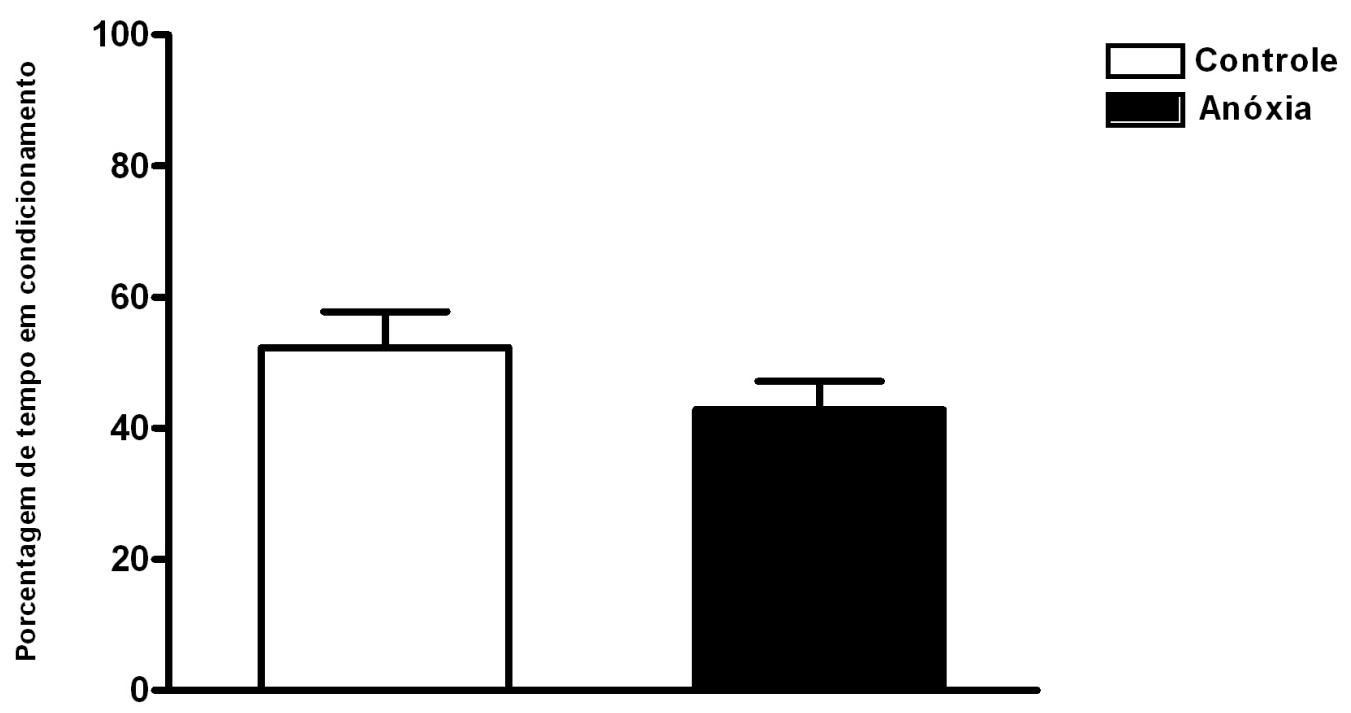

Figura 24. Porcentagem do tempo total em congelamento (média \pm erro padrão) dos animais anoxia $(n=13)$ e controle $(n=12)$ durante o teste de medo condicionado ao contexto 
Observou-se que houve aumento gradativo de ambos os grupos ao longo dos três primeiros minutos e posterior decréscimo quanto à porcentagem de tempo de congelamento do terceiro para o quarto minuto. Verificou-se que o tempo de congelamento dos animais anóxia se mostra inferior quando comparado aos animais controle, conforme ilustra a figura 25. O teste revelou diferença próximo da significância no quarto minuto entre os animais anóxia e controle ( $\mathrm{P}=$ 0,090), porém inexistência de diferença significativa nos demais minutos.

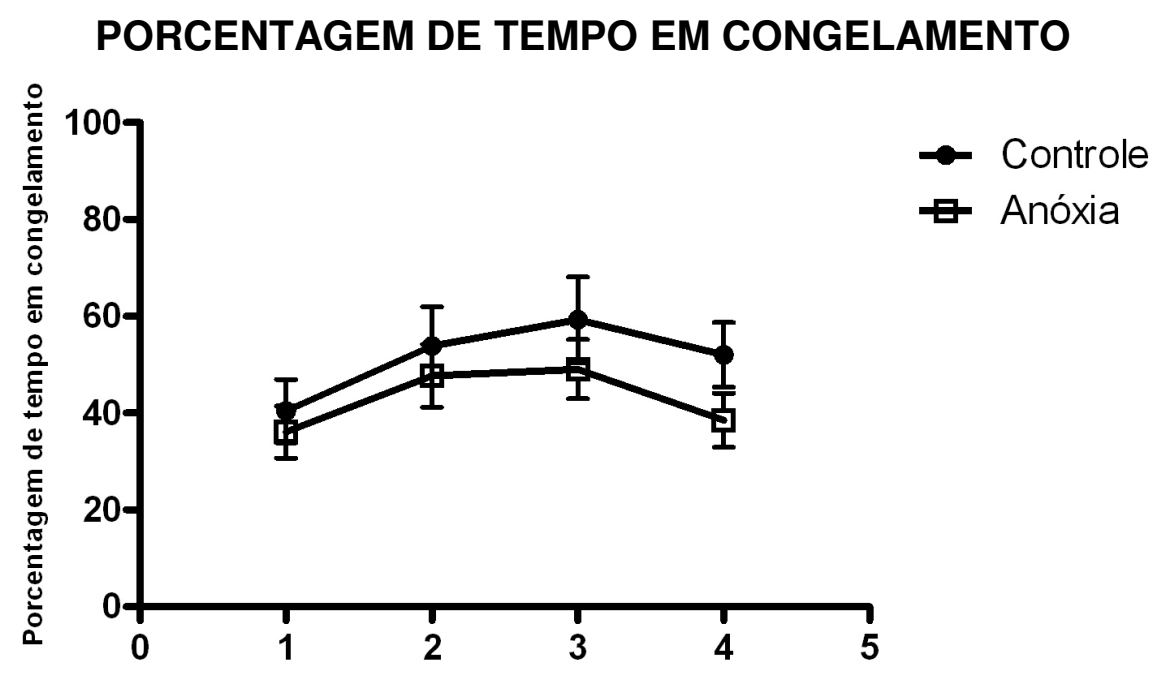

Figura 25. Porcentagem do tempo total em congelamento (média \pm erro padrão) dos animais anóxia $(n=13)$ e controle $(n=12)$ durante o teste de medo condicionado ao contexto. 
No teste de medo condicionado ao som, os resultados evidenciaram que os animais anóxia, permaneceram menor tempo em congelamento quando comparado aos animais controle, conforme ilustra a figura 26. O teste revelou diferença significante com relação à porcentagem de tempo em congelamento entre os animais dos grupos anóxia e controle $(P=0,042)$.

PORCENTAGEM DE TEMPO EM CONGELAMENTO

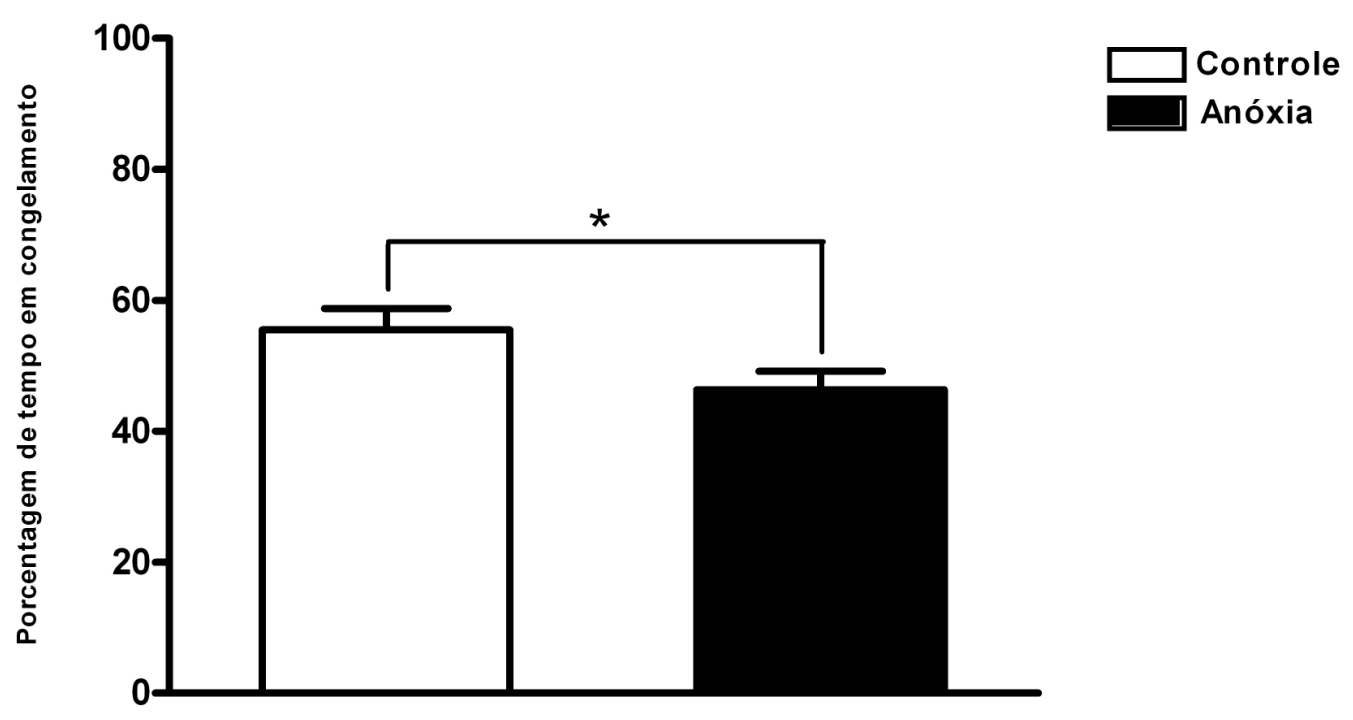

Figura 26. Porcentagem do tempo total em congelamento (média \pm erro padrão) dos animais anóxia $(n=13)$ e controle $(n=12)$ durante o teste de medo condicionado ao som. 
Por fim, com relação à porcentagem de tempo em congelamento ao longo dos oito minutos, observou-se que houve aumento gradativo de tempo em congelamento em ambos os grupos até o quarto minuto e posterior decréscimo também gradativo até o oitavo minuto, conforme ilustra a figura 27. Os resultados revelaram existência de diferença significante entre grupos, no terceiro minuto $(P=$ 0,050 ), tendo sido verificado que os animais controle permaneceram maior porcentagem de tempo em congelamento quando comparado aos animais anóxia. Nos demais minutos não se observou diferenças significativas.

PORCENTAGEM DE TEMPO EM CONGELAMENTO

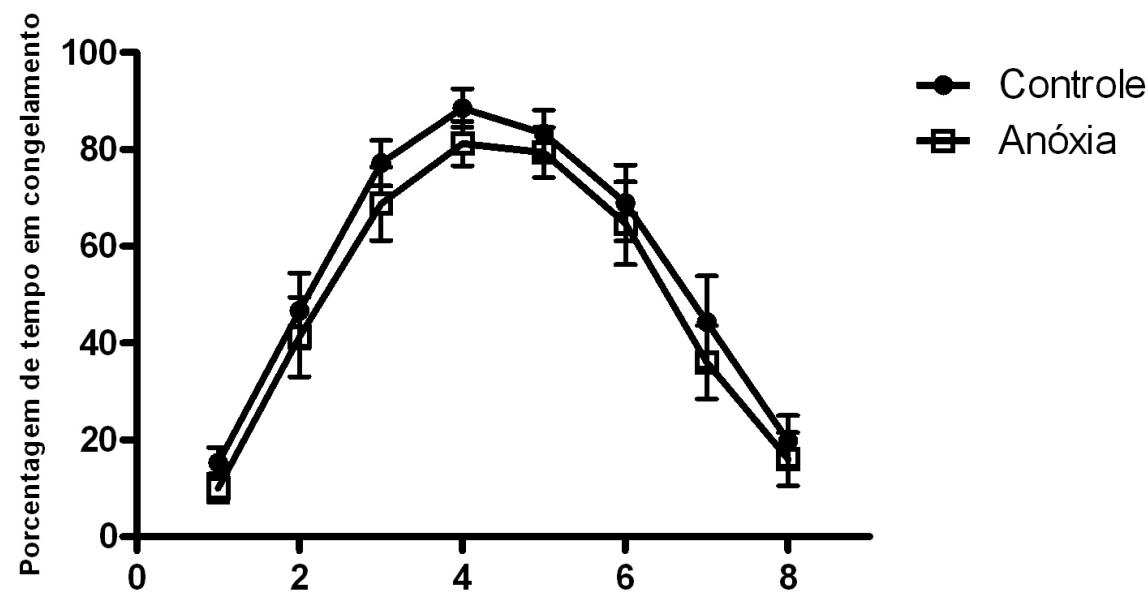

Figura 27. Porcentagem do tempo total em congelamento (média \pm erro padrão) dos animais anóxia $(n=13)$ e controle $(n=12)$ durante o teste de medo condicionado ao som. 


\subsection{DISCUSSÃO}

A privação de oxigênio é considerada potencialmente perigosa, uma vez que corresponde a um dos eventos que pode causar danos ao encéfalo em desenvolvimento (estrutura mais susceptível no neonato), e acarretar em distúrbios comportamentais que pode persistir por toda a vida do indivíduo afetado.

Várias espécies de mamíferos têm contribuído no estudo com modelos animais. Em particular roedores tem sido utilizados com sucesso, como modelo da hipóxia, em humanos. $\mathrm{O}$ rato nasce prematuramente, quando comparado ao humano, pois o estágio de maturação encefálica do rato neonato é comparável ao final do segundo trimestre em humanos, ou seja, por volta da vigésima quarta semana de gestação.

O nível de maturidade do encéfalo de um rato de 10 dias de vida pós-natal se aproxima ao estágio de desenvolvimento de um encéfalo de humano recém nascido a termo (Nyakas et al., 1996).

A literatura cita diferentes metodologias utilizadas para provocar privação de oxigênio em ratos antes, durante ou logo após o nascimento: a hipóxiaisquemia, a asfixia perinatal, e a anóxia neonatal.

$\mathrm{O}$ modelo adaptado e validado em nosso laboratório e empregado no presente estudo, foi o modelo de anóxia neonatal, que reproduz o modelo descrito na literatura onde o ar ambiente no interior de uma câmara é substituído por nitrogênio gasoso $100 \%$, na tentativa de simular o insulto anóxico que acomete o prematuro humano com cerca de 24 semanas (Takada, 2009). Este modelo é o de escolha de autores interessados em pesquisar seqüelas comportamentais decorrentes da privação de oxigênio, este método não é invasivo e possui menos variáveis de estresse, uma vez que não é necessária a eutanásia da mãe dos animais e sua substituição por outra fêmea, como ocorre no modelo da asfixia perinatal, também não acomete o encéfalo de forma assimétrica como ocorre na hipóxia-isquemia o que acaba por dificultar a análise comportamental. 
As áreas mais susceptíveis à morte neuronal após privação de oxigênio e citadas na literatura são: hipocampo, núcleos da base e córtex cerebral (Aden et al., 1994; Dell'Anna et al., 1995; Oorshchot et al., 2000)

No encéfalo, as diferentes demandas metabólicas tornam algumas regiões mais susceptíveis à anóxia que outras (Oliveira-Alonso e Silveira, 2007). Em ordem decrescente de demanda metabólica, pode-se citar: lobo frontal, seguido pelos lobos occipital, parietal e temporal, cerebelo e núcleos da base e, por último, o tronco encefálico. Desta forma, a primeira região a ser lesada com a anóxia seria o córtex cerebral do lobo frontal e, dependendo da gravidade da anóxia, outras regiões seriam lesadas, sendo o tronco encefálico o último a ser acometido (Oliveira-Alonso e Silveira, 2007).

\subsection{Efeitos da anóxia neonatal no desempenho das tarefas de memória de referência espacial, memória operacional (dez, trinta e zero) e plataforma visível no labirinto aquático de Morris.}

No labirinto aquático de Morris, os resultados envolvendo os parâmetros latência e comprimento do trajeto, são usualmente tomados como indicadores da capacidade de aprendizagem e navegação espacial (Morris et al., 1982; Morris, 1983; Xavier et al., 1999).

No presente estudo, no teste que avalia a memória de referência espacial, os resultados envolvendo a latência para encontrar a plataforma mostraram que ambos os grupos (anóxia e controle) exibiram melhora de desempenho ao longo de das tentativas e dias de teste, ou seja, os dois grupos de animais foram capazes de adquirir informações relevantes para o desempenho da tarefa. Estes resultados vão ao encontro à literatura que usualmente descreve sobre a aprendizagem de ratos nesse tipo de tarefa, onde a taxa de redução dos escores, assim como o desempenho final alcançado pelos animais ao final do treino são melhores (Morris et al., 1982; Morris, 1983). Isto é, ratos jovens treinados no labirinto aquático de Morris exibem acentuada curva de aprendizagem, atingem 
níveis de desempenho expressos por menores latências e comprimentos de trajeto, com menor quantidade de treino. Apesar de ambos os grupos terem demonstrado capacidade de aprendizagem, observou-se que os animais anóxia, apresentaram desempenho inferior neste teste, expresso por latências maiores, quando comparado aos animais controle. Estes dados confirmam à literatura que descreve que os animais anóxia apresentam latências maiores quando comparado aos animais controle (Dell'Anna et al., 1997; Simonova et al., 2003; Kheirandish et al., 2005; Chen et al., 2007).

Não foi possível mensurar o comprimento do trajeto, bem como a velocidade do nado, no teste de memória de referência espacial de ambos os grupos, por problemas do sistema de programação do teste, o que comprometeu a avaliação destes resultados.

O teste envolvendo a memória operacional no labirinto aquático oferece a possibilidade de realizar avaliação entre a obtenção e o uso da informação, ou seja, uma vez que a localização da plataforma é modificada a cada dia de teste, o viés espacial em direção à localização da plataforma no dia anterior consiste em um teste de memória espacial, com vinte e quatro horas de retardo; ademais, seu decréscimo ao longo das tentativas expressa a extinção dessa resposta em associação com a aquisição da informação sobre a nova localização da plataforma.

Considerando o parâmetro - latência, no que se refere aos testes envolvendo memória operacional, intervalo entre as tentativas (ITI) dez, trinta e zero, observou-se que não houve diferenças significantes quanto ao desempenho dos animais, quando considerados diferentes intervalos de tempo, podendo sugerir que não há prejuízo relevante, com a diminuição ou aumento do ITI, ou seja, os animais de ambos os grupos, não demonstraram dificuldade para reter a informação espacial por períodos mais curtos ou prolongados de tempo. No estudo realizado por Simonova (2003), observou-se que tanto os animais anóxia quanto os animais controle, demonstraram habilidades para localizarem a plataforma, entretanto, foi observado uma lentificação no aprendizado dos animais anóxia, constatado por maior latência, quando comparado ao outro grupo. Os 
animais de ambos os grupos, não demonstraram dificuldade para reter a informação espacial por períodos mais curtos ou prolongados de tempo. No estudo realizado por Simonova (2003), observou-se que tanto os animais anóxia quanto os animais controle, demonstraram habilidades para localizarem a plataforma, entretanto, foi observado uma lentificação no aprendizado dos animais anóxia, constatado por maior latência, quando comparado ao outro grupo. Também evidenciam que o insulto anóxico/hipóxico, acarreta em prejuízo no desempenho dos animais anóxia, que acabam apresentando latência maior quando comparado aos animais controle (Dell'Anna et al., 1997; Simonova et al., 2003; Kheirandish et al., 2005; Chen et al., 2007).

Resultados similares foram verificados quanto ao comprimento do trajeto, quando o ITI diferia, ou seja, os animais de ambos os grupos, não demonstraram dificuldade para reter a informação espacial por períodos mais prolongados de tempo, indicando que ambos diminuíram o comprimento do trajeto no decorrer das tentativas do mesmo dia de teste. Estudos revelam que os animais anóxia apresentam dificuldade quanto ao aprendizado e memória espacial (Hedner e Lundborg, 1980; Dell'Anna et al., 1995a; Dell'Anna et al., 1997; Wainwright et al., 2004; Casolini et al., 2005; Chen, et al., 2007; Rogalska et al., 2006), o que acarreta comprometimento na navegação espacial, caracterizado não apenas por uma maior latência como por maior comprimento do trajeto para encontrar a plataforma (Chen et al., 2007; Kheirandish et al., 2005). No presente estudo, este comportamento foi observado uma vez que os animais anóxia apresentaram desempenho inferior (comprimento do trajeto maior) quando comparado aos animais controle, quando o ITI foi de dez minutos e zero, porém esta diferença não foi observada quando o ITI aumentou para trinta minutos.

Verificou-se que tanto os animais controle quanto os animais anóxia, conseguiram utilizar da informação sobre a localização da plataforma adquirida na primeira tentativa para utilizá-la na segunda e demais tentativas do mesmo dia, o que aparentemente facilitou o desempenho destes animais. Observou-se também que à medida que os animais passavam pelos diferentes testes (memória de referência espacial, memória operacional nos ITI 10, 30 e 0) valiam-se de suas 
experiências prévias para melhorarem seu desempenho nas tarefas no labirinto aquático de Morris, expressos por meio da redução na latência e comprimento do trajeto, sendo esta melhora no desempenho inferior nos animais anóxia. Estes necessitaram de mais dias de testes, para atingirem desempenho próximo aos encontrados nos animais do outro grupo. Observação similar é verificada em humanos, onde crianças com ferimentos hipóxicos-isquêmicos, obtêm nível de desempenho inferior quando comparado aos colegas saudáveis nos testes acadêmicos para leitura, escritos ou aritméticos, demandando tempo maior para alcançarem melhor desempenho (Zubrick et al., 1988).

Observou-se diferença similar à latência e comprimento do trajeto, no que se refere aos resultados envolvendo velocidade média do nado, quando comparado os dois grupos. Este parâmetro é calculado a partir do comprimento do trajeto e da latência; divide-se o comprimento do trajeto pela latência. Os resultados demonstram que nos testes envolvendo memória operacional, ITI dez, trinta e zero, observou-se nos três intervalos de tempo, houve variação quanto à velocidade do nado ao longo dos dias e tentativas de testes. Perceberam-se diferenças significantes quanto à velocidade, quando comparado o grupo anóxia ao controle, tendo os animais anóxia apresentado velocidade do nado inferior quando comparado aos animais controle.

Como a velocidade do nado envolve a razão entre comprimento do trajeto e latência, nos animais controle isso envolve a razão entre comprimentos de trajetos menores e latências menores e velocidade de nados maiores. Inversamente, nos animais anóxia isso envolve a razão entre comprimentos dos trajetos maiores e latências maiores, resultando em velocidades de nado significativamente menores. A velocidade do nado no labirinto aquático é tomada como indicador da motivação dos animais para saírem da água (Morris et al., 1982; Morris, 1993). Frente a esta questão, observou-se pelos resultados que ambos os grupos apresentam esta motivação, apesar dos animais do grupo anóxia apresentar velocidade inferior quando comparado aos animais controle. Um fator interessante observado durante os experimentos e confirmado ao término dos mesmos, é que animais anóxia apresentaram peso superior aos animais controle, diferença aproximada de 100 
gramas. Estudos evidenciam nos animais anóxia apresentam uma acentuada hiperatividade na idade infantil (Speiser et al., 1983; Dell'Anna et al., 1991; Volpe, 1992; Buwalda, 1995; Farone e Biederman, 1998; Vannucci et al., 1999; Cannon et al., 2002; Caputa et al., 2005) acompanhada por uma significante hipoatividade na idade adulta (Nyakas et al., 1996;Loidl et al., 2000; Venerosi, 2004), o que pode ter causado o aumento de peso destes animais e conseqüentemente a velocidade inferior do nado.

No teste no labirinto aquático com plataforma visível, os animais necessitam aprender a associar uma dica visual (um cilindro branco fixado em cima da plataforma) com a resposta de se aproximar desta dica. Este é utilizado também para avaliar a presença de distúrbios sensoriomotores (Row et al., 2002). Neste teste onde a plataforma é visível ou sinalizada por uma dica colocada em cima da própria plataforma, o animal pode ignorar as outras pistas externas e aprender a relação entre a posição da dica que sinaliza a posição da plataforma por si só com a resposta de se aproximar desta pista, para tanto é necessário que o animal apresente acuidade visual preservada. Considerando estas questões, com relação aos parâmetros latência e comprimento do trajeto, pode se observar através dos resultados do presente estudo, que tanto os animais anóxia quanto os animais controle, foram capazes de adquirirem informações relevantes para o desempenho desta tarefa. Porém observou-se que os animais anóxia demonstraram desempenho inferior para encontrar a plataforma visível, quando comparado aos animais controle.

Estudos revelam que os animais anóxia podem apresentar déficit sensoriomotor (Robertson e Finer, 1993) e deficiências visuais (Johnston, 2002), dificuldades estas não observadas nos animais anóxia do presente estudo. Similarmente, aos testes anteriores, os animais anóxia demonstraram velocidade do nado significativamente inferior quando comparado aos animais controle. 


\subsection{Efeitos da anóxia neonatal no desempenho do teste do labirinto em cruz elevado.}

Os braços abertos, no labirinto em cruz elevado, representam um ambiente aversivo. Na primeira exposição ao labirinto, os animais investigam tanto os braços abertos como os braços fechados, mas o fazem com cautela, em particular os braços abertos, pois esses animais aparentemente exibem medo incondicionado a espaços abertos e a altura (File, 1992; File 1993; Wall e Messier, 2001; Pinheiro, 2007). Dentro deste contexto, os resultados do presente estudo mostraram que os animais controle, exibiram porcentagem menor de entrada nos braços abertos, quando comparados aos animais anóxia, na primeira sessão, ou seja, os animais experimentais mostraram-se menos ansiosos quando comparado aos animais do outro grupo.

De fato, ratos tratados com drogas ansiolíticas tendem a aumentar a porcentagem de tempo de permanência nos braços abertos, enquanto que os animais tratados com drogas ansiogênicas tendem a permanecer relativamente menos tempo nesses braços (Pellow e File, 1986; Lister, 1987; Handley e Mcblane, 1993; Rodgers e Cole, 1994; Holmes e Rodgers, 1999). Pensa-se que a altura não é o fator crítico indutor de ansiedade, sendo a aversão decorrente do espaço aberto e da impossibilidade de realizar tigmotaxia positiva, o comportamento de exploração tátil do ambiente através das vibrissas, tão comum nesses animais (Falter et al., 1992; Triet et al., 1993; Cardenas et al., 2001).

O desempenho no labirinto em cruz elevado parece depender de um conflito entre duas características dos ratos; aversão por espaços abertos e tendências de explorar ambientes novos (Pellow, 1985; Handley e McBlane, 1993; Treit et al., 1993; Fernandes e File, 1996). Assim, na primeira sessão os animais tendem a explorar o novo ambiente, adquirindo informações sobre o mesmo (File, 1992). Porém, depois dessa primeira experiência e, portanto, depois dessa aquisição de informações sobre esses ambientes, tipicamente ratos aumentam sua esquiva aos braços abertos, pois além do medo incondicionado, há também o medo condicionado decorrente da primeira experiência com esse estímulo 
aversivo (File, 1993; Graeff 1999). Estes dados vão ao encontro, com o que foi observado neste estudo, uma vez que se verificou que, tanto os animais anóxia quanto os animais controle, exibiram uma redução na percentagem de entradas e na percentagem de tempo nos braços abertos na segunda sessão em relação à primeira, sendo a diferença nos animais anóxia estatisticamente significativa.

O labirinto em cruz elevado permite a avaliação da ansiedade: quanto menor a percentagem de entradas e de tempo nos braços abertos maior a ansiedade (Handley e Mithani, 1984; Pellow e File, 1986), bem como permite avaliar também, a memória dos animais em relação àquele ambiente aversivo. Neste estudo observou-se que, na primeira sessão, os animais anóxia entraram e permaneceram maior porcentagem de tempo nos braços abertos, demonstrando assim, menor ansiedade do que os animais controle. A ansiedade, quando manifestada em níveis adequados, parece ser importante para a motivação de um bom desempenho do indivíduo, ativando e mobilizando o organismo à sua adaptação ao ambiente, por outro lado, a ansiedade diminuída, favorece com que o animal se exponha mais às situações de perigo. Observou-se também, que este tipo de lesão não alterou a capacidade dos animais anóxia e nem dos animais controle de adquirirem memória sobre a experiência aversiva, que contribuiu para uma maior esquiva dos braços abertos na segunda sessão.

No labirinto em cruz elevado, a principal medida para se avaliar a atividade locomotora nos animais é a freqüência de entrada nos braços fechados (File, 1992; Graeff et al.,1993; Cruz et al., 1994; Rodgers e Johnson, 1995). No presente experimento observou-se apenas na primeira sessão, que os animais anóxia entraram com menor freqüência nos braços fechados quando comparado aos animais controle. Como esperado, observou-se que ambos os grupos na segunda sessão, apresentaram maior freqüência de entradas nos braços fechados, quando comparado à primeira sessão, tendo os dois grupos apresentado resultados similares.

O tempo de permanência e o número de cruzamentos no quadrado central refletiriam a avaliação do risco desse ambiente pelos animais. No presente estudo, não foi observado diferença entre os grupos em relação ao número de 
cruzamentos no quadrado central. Porém, observou-se que os animais anóxia, nas duas sessões, permaneceram maior tempo no quadrante central, quando comparado aos animais controle, sendo esta diferença significativa na primeira sessão.

\subsection{Efeitos da anóxia no teste do medo condicionado ao contexto e no teste de medo condicionado ao som.}

O aprendizado sobre um contexto parece envolver a integração de uma multiplicidade de estímulos elementares, de uma variedade de modalidades, em uma única representação. Desta forma, após o teste de medo condicionado a um contexto, as respostas condicionadas não são eliciadas por componentes únicos do contexto, mas pela configuração dos múltiplos elementos constituintes do contexto em questão.

Vários modelos animais envolvem processos de aprendizagem associativa baseados no condicionamento clássico. No condicionamento clássico, os estímulos neutros (condicionados), como por exemplo, sons e luzes, quando associados a estímulos aversivos (incondicionados), como choques elétricos e sons intensos, podem desencadear respostas de medo/ansiedade (resposta condicionada). A partir daí, esses estímulos neutros passariam a desencadear as respostas de medo/ansiedade em decorrência de anteciparem para o animal a apresentação de um estímulo aversivo.

Os resultados obtidos no presente estudo indicam que, em geral, ambos os grupos aprenderam a associar o estímulo incondicionado com o condicionado, demonstrado pelo tempo em que ambos permaneceram em congelamento. $O$ congelamento é um padrão comportamental complexo e coordenado caracterizado pela ausência de todos os movimentos corporais, exceto movimentos respiratórios

A anóxia neonatal parece não ter afetado a capacidade associativa do ambiente com a experiência negativa (choque nas patas), pois no teste de medo condicionado ao contexto, os animais anóxia apresentaram apenas diferença 
próximo da significância no quarto minuto quando comparado aos animais controle, ou seja, a anóxia parece não ter influenciado na aprendizagem das características contextuais em que o condicionamento ocorreu. Por outro lado, no teste de medo condicionado ao som (no momento em que o som foi reapresentado em outro contexto), os animais anóxia apresentaram latência inferior, representado por um menor tempo em congelamento quando comparado aos animais controle. No teste, o aumento da expressão do comportamento de congelamento, quando o sujeito experimental está na presença de um único estímulo condicionado, indica a capacidade associativa deste sujeito. Estes dados se mostram similares aos resultados obtidos por Bonsignore (2006) em seu estudo, onde a asfixia perinatal, interferiu no teste de medo condicionado ao som, porém não ao contexto. 


\subsection{CONCLUSÕES}

Considerando os resultados obtidos, pode-se concluir que:

- O modelo experimental de anóxia neonatal utilizado é valido e eficiente para produzir privação temporária de oxigênio no encéfalo dos neonatos, produzindo alterações em vários parâmetros comportamentais.

- O estímulo de anóxia neonatal causou prejuízo na capacidade de aprendizagem e navegação espacial, demonstrados através dos testes de memória de referência espacial e memória operacional, no labirinto aquático de Morris.

- O intervalo mais prolongado de tempo entre as tentativas, parece não ter interferido na retenção de informação espacial dos dois grupos, tendo os mesmos, conseguido valerem-se das suas experiências prévias para melhorarem seu desempenho na medida em que passavam pelos diferentes testes (memória de referência espacial, memória operacional com intervalo entre as tentativas de 10 , 30 e 0) demonstrados por meio da diminuição na latência e do comprimento do trajeto, sendo esta melhora no desempenho inferior nos animais anóxia. Estes necessitaram de mais dias de testes, para atingirem desempenho próximo ao encontrado nos animais do outro grupo.

- Ambos os grupos, demonstraram motivação para saírem da água nos testes realizados no labirinto aquático de Morris. Houve variações na velocidade do nado ao longo dos dias de testes tanto dos animais experimentais quanto dos controles, porém, os animais anóxia demonstraram velocidade inferior aos animais controle. Os animais anóxia apresentaram peso superior aos animais do outro grupo (cerca de 100 gramas), que pode ter ocorrido em função destes apresentarem acentuada hiperatividade na vida infantil, acompanhada por hipoatividade na vida adulta, o que pode ter contribuído para o aumento do peso destes animais e conseqüentemente a velocidade inferior do nado.

- Os animais anóxia, demonstraram menor ansiedade quando comparado aos animais controle, o que levou a um maior tempo de exposição destes, às 
situações de perigo; a ansiedade quando manifestada em níveis adequados, parece ser importante para a motivação de um bom desempenho do indivíduo, ativando e mobilizando o organismo à sua adaptação ao ambiente.

- A anóxia neonatal parece não ter afetado a capacidade associativa do ambiente com a experiência negativa (choque nas patas), ou seja, parece não ter influenciado na aprendizagem das características do contexto em que 0 condicionamento ocorreu. Por outro lado, no teste de medo condicionado ao som (no momento em que o som foi re-apresentado em outro contexto), os animais anóxia apresentaram latência inferior, representado por um menor tempo em congelamento quando comparado aos animais controle.

- Este estudo indica que o modelo de anóxia neonatal utilizado promove alterações neuronais que modificam o comportamento do animal, verificados por meio das alterações comportamentais na vida adulta. 


\subsection{REFERÊNCIAS BIBLIOGRÁFICAS}

Adén, U.; Bona, E.; Hagberg, H.; Fredholm, B.B. (1994). Changes in c-fos mRNA in the neonatal rat brain following hypoxic ischemia. Neuroscience Letters, v. 180, p. 91-95.

Andrade, T.G.; Silva, A.M.; Silva, C.L. e Graeff, F.G. (1999). Effect of eletrolytic lesion of the median raphe nucleus on behavioral and physiological measures of stress. Acta Physiol. Pharmacol. Ther. Latinoam., v. 49 (4), p. 279-289.

Azrin, N.H.; Ulrich, R.E.; Hutchinso, R.R. e Norman, D.C. (1964). Effect of shock duration on shock-induced fighting. J. Exp. Anal. Behav., v.7, p. 9-11.

Baladi, A. B. P. C.; Castro, N. M. D.; Morais Filho, M. C. (2007). Paralisia cerebral. In: Fernandes, A. C., Ramos, A. C. R., Casalis, M. E. P., Hebert S. K. (Ed.) AACD Medicina e Reabilitação: princípios e prática. São Paulo: Artes Médicas, p. 15-34.

Bandler, R. e Carrive, P. (1988). Integrated defence reaction elicited by excitatory amino acid microinjection in the midbrain periaqueductal grey region of the unretrained cat. Brain Res., 439, p. 95-106.

Barros, R. C.; Branco, L. G.; Cárnio, E. C. (2006). Respiratory and body temperature modulation by adenosine $A 1$ receptors in the anteroventral preoptic region during normoxia and hypoxia. Respiratory Physiology \& Neurobiology, v. 153 , n. 2, p. 115-125.

Bavis, R. W. (2005). Developmental plasticity of the hypoxic ventilatory response after perinatal hyperoxia and hypoxia. Respiratory Physiology \& Neurobiology, v. 149 , n. $1-3$, p. $287-299$.

Bear, M.F.; Connors, B.W. e Paraiso, M.A. (2002). Neurociências: desvendando o sistema nervoso. 2. ed. Porto Alegre, Artmed, p. 799.

Berger-Sweeney, J.; Hohmann, C. F. (1997)Behavioral conequences of abnormal cortical development: insights into developmental disabilities. Behavioral Brain Research, v. 86, n. 2, p. 121-142

Bjelke B.; Nyakas C.; Vosselman H. J.; Luiten P. G. (1991). Asphyctic lesion: proliferation of tyrosine hydroxylase-immunoreactive nerve cell bodies in the rat substantina nigra and functional chabges in dopamine neurotransmission. Brain Res. v. 543, p. 1-9.

Blanchard, R.J., Flannelly, K.J. e Blanchard, D.C. (1986). Defensive reactions of laboratory and wild Rattus norvegicus. J. Comp. Physiol. Psychol., v. 100, p. 101107. 
Blanchard, R.J. e Blanchard, D.C. (1987). An ethoexperimental approach to the study of fear. Psychol. Rec., v.37, p. 305-316.

Blanchard, D.C. e Blanchard, R.J. (1988). Ethoexperimental approaches to the biology of emotion. Ann. Rev. Pshychol., v.39, p. 43-68.

Bohr, I. (2004). Hypercholesterolemic diet applied to rat dams protects their offspring against cognitive deficits. Simulated neonatal anoxia model. Physiology \& Behavior, v. 82, n. 4, p. 703-711.

Bolles, R.C. e Rilley, A.L. (1973). Freezing as an avoidance response: another look at the operant-respondent distinction. Learn. Motiv., v. 4, p.268-275.

Bolles, R.C. e Collier, A.C. (1976). The effect of predictive cues on freezing in rats. Animal Learn. Behav., v.4, p. 6-8.

Bonhan, A.C. (1995). Neurotransmitters in the CNS control of breathing. Respiratory Physiology, v. 101, p. 219-30.

Bonsignore L. T. (2006). Acute perinatal asphyxia at birth has long-term effects on behavioural arousal and maternal behaviour in lactating rats. Behavioural Brain Research, v. 172, p. 54-62.

Bouton, M.E. e Bolles, R.C. (1980). Conditioned fear assessed by freezing and by the suppression of three different baselines. Animal Learning Behavioural., v.8, p. 429-434.

Brixley S.N.; Gallagher B.J.; Mcfalls, J.A.JR.; Parmelle, L.F. (1993). Gestacional and neonatal factors in the etiology of schizophrenia. Journal of Clinical Psychology, v.49, p. 447-456.

Buwalda, B.; Nyakas, C.; Vosselman, H.J.; Luiten, P.G.M. (1995). Effects of early postnatal anoxia on adult learning and emotion in rats. Behavioural Brain Research, v. 67 , p. 85-90.

Cannon, M.; Jones, P.B.; Murray, R.M. (2002). Obstetric complications and schizophrenia: historical and meta-analyric review. American Journal of Psychiatry, v. 159 , p. $1080-1092$.

Caputa, M.; Rogalska, J.; Wentowska, K.; Nowakowska, A. (2005). Perinatal asphyxia, hyperthermia and hyperferremia as factors inducing behavioural disturbances in adulthood: a rat model. Behavioral Brain Research, v. 163, n. 2, p. 246-256. 
Cardenas, F.; Lamprea, M.R.; Morato, S. (2001). Vibrissal sense is not the main sensory modality in rat exploratory behavior in the elevated plus-maze. Behavioural Brain Research, v. 122, p. 169-74.

Casolini, P.; Zuena, A. R.; Cinque, C.; Matteucci, P.; Alema, G. S.; Adriani, W.; Carpinelli, G.; Santoro, F.; Alleva, E.; Bosco, P.; Nicoletti, F.; Laviola, G.; Catalani, A. (2005). Sub-neurotoxic neonatal anoxia induces subtle behavioural changes and specific abnormalities in brain group-I metabotropic glutamate receptors in rats. Journal of Neurochemistry, v. 95, n. 1, p. 137-145.

Cirulli, F.; Bonsignore, L. T.; Venerosi, A.; Valanzano, A.; Chiarotti, F.; Alleva, E. (2003). Long-term effects of acute perinatal asphyxia on rat maternal behavior. Neurobiology and Teratology, v. 25, p. 571-578.

Cohen, M. (1973). Biochemistry of cerebral anoxia, hypoxia and ischemia. Monographs in Neural Science. p. 1- 49.

Chowdhury, R.; Hardy, A.; Schofield, C. J. (2008). The human oxygen sensing machinery and its manipulation. Chemical Society Reviews, v. 37, n. 7, p. 13081319.

Coq, J. Q.; Strata, F.; Russier, M.; Safadi, F. F.; Maerzenich, M. M.; Byl, N. N.; Barbe, M. F. (2008). Impact of neonatal asphyxia and hind limb immobilization on musculoskeletal tissues and S1 map organization: implications for cerebral palsy. Experimental Neurology, v. 210, n. 1, p. 95-108.

Cohen, G.; Malcol, G.; Henderson-Smart, D. (1997). Ventilatory response of the newborn infant to mild hypoxia. Pediatric Pulmonology, v. 24, n. 3, p. $163-172$.

Costa, V.C.I.; Bueno, J.L.O.; Xavier, G.F. (2005). Dentate gyrus-selective colchicines lesion and performance in temporal and spatial tasks. Behavioural Brain Research, v.160, p. 286-303.

Costello, A. M.; Manandhar, D. S. (1994). Perinatal asphyxia in less developed countries. Archives of disease in childhood. Fetal and neonatal edition, v. 71, n. 1, p. 1-3.

Cruz, A. P. M., Frei, F., Graeff, F. G. (1994). Ethopharmacological analysis of rat behavior on the elevated plus-maze. Pharmacology Biochemistry and Behavior, $v$. 49, p.171-176.

Chan, K-H.; Morell, J.R.; Jarrard, L.E. e Davidson, T.L. (2001). Reconsideration of the role of hippocampus learned inhibition. Behavioural Brain Research., v. 119 , p. 111-130. 
Chen, W. F.; Chang, H.; Wong, C. S.; Huang, L. T.; Yang, C. H.; Yang, S. N. (2007). Impaired expression of postsynaptic density proteins in the hippocampal CA1 region of rats following perinatal hypoxia. Experimental Neurology, v. 204, n. 1 , p. 400-410.

Darwin, C. (1872). The expression of emotion in men and animals. Philosophical Library, New York (reprint 1985), p. 134.

Davis, J. N.; Carlsson, A.; Macmillan, V.; Siesjo, B. K. (1973). Brain tryptophan hydroxylation: dependence on arterial oxygen tension. Science, v. 182, n. 107, p. 72-4.

Dell'Anna, M. E.; Calzolari, S.; Molinari, M.; luvone, L.; Calimici, R. (1991). Neonatal anoxia induces transitory hyperactivity, permanent spatial memory deficits and CA1 cell density reduction in developing rats. Behavioral Brain Research, v. 45, n2, p. 125-134.

Dell'Anna, M. E.; Luthman, J.; Lindqvist, E.; Olson, L. (1993). Development of Monoamine Systems After Neonatal Anoxia in Rats. Brain Research Bulletin, v. 32, p. 159-170.

Dell'Anna, M. E.; Geloso, M.C.; Draisci, G.; Luthman, J. (1995a). Transient Changes in Fos and GFAP Innumoreactivity Precede Neuronal Loss in the Rat Hippocampus Following Neonatal Anoxia. Experimental Neurology, v. 131, p. 144156.

Dell'Anna, M. E.; Chen, Y.; Loidl, F.; Andersson, K.; Luthman, J.; Goiny, M.; Rawal, R.; Lindggren, T.; Herrera-Marschitz, M. (1995b). Short-Term Effects of Perinatal Asphyxia Studied with Fos-Immunocytochemistry and in Vivo Microdialysis in the Rat. Experimental Neurology, v. 131, p. 279-287.

Dell'Anna, M. E.; luvone, L.; Calzolari, S.; Geloso, M.C. (1997). Effect of acetyl-Lcarnitine on hyperactivity and spatial memory deficits of rats exposed to neonatal anoxia. Neuroscience Letters, v. 223, p. 201-205.

Di Pasquale, E.; Morin, D.; Montreau, R.;Hillaire, G. (1992). Serotonergic modulation of the respiratory rhythm generator at birth: an in vitro study in the rat. Neuroscience Letters, v.143, p. 91- 95.

Dobbing, J. (1968). The development of the blood-brain barrier. Progress in Brain Research, v. 29, p. 417-427.

Dobbing, J. (1970). The effects of early growth retardation on the human brain: the usefulness of animal experiments. Journal of Pathology, v. 101, n. 4, p.13.

Dratcu, L. e Lader, M. (1993). Ansiedade: conceito, classificação e biologia. J. Bras. Psiq., v. 42, p.19-32. 
Dreyer, P.I. e Church, R. (1968). Shock-induced fighting as a function of the intensity and duration of the aversive stimulus. Psychonom. Sci., v.10 p. 271272.

Doi, A.; Ramirez, J. M. (2008). Neuromodulation and the orchestration of the respiratory Rhytm. Respiratory Physiology\&Neurobiology, in press.

El-Khodor, B.; Boska, P. (2003). Differential vulnerability of male versus female rats to long-term effects of birth insult on brain catecholamine levels. Experimental Neurology, v. 182, p. 208-219.

En Elnazir, B.; Marshall, J. M.; Kumar, P. (1996). Postnatal development of the pattern of respiratory and cardiovascular response to systemic hypoxia in the piglet: the roles of adenosine. Journal of Physiology, v. 492, p. 573-585.

Engidawork, E.; Chen, Y.; Dell'Anna, E.; Goiny, M.; Lubec, G.; Ungerstedt, U.; Andersson, K.; Herrera-Marschitz, M. (1997). Effect of perinatal asphyxia on systemic and intracerebral $\mathrm{pH}$ and glycolysis metabolism in the rat. Experimental Neurology, v. 145, p. 390-396.

Dell'Anna, E.; Goiny, M.; Lubec, G.; Ungerstedt, U.; Aandersson, K.; HerraraMarschitz, M. (1997). Effect of perinatal asphyxia on systemic and intracerebral pH and glycolysis metabolism in the rat. Experimental Neurology, v. 145, p. 390-396.

Falter, U.; Gower, A.J.; Gobert, J. (1992). Resistance of baseline activity in the elevated plus-maze to exogenous influences. Behavioral Pharmacology, v. 3; p.123-28.

Fandrey, J.; Gorr, T. A.; Gassmann, M. (2006). Regulating cellular oxygen sensing by hydroxylation. Cardiovascular Research, v. 71, n. 4, p. 642-651.

Fanselow, M.S.; Sigmundi, R. A. e Bolles, R. C. (1980). Naloxone pretreatment enhances shock-elicited aggression. Physiol. Psychol., v. 8, n. 3, p. 369-371.

Fanselow, M.S. e Baackes, M.P. (1982). Conditioned fear-induced opiate analgesia on the formalin test: evidence for two aversive motivational systems. Learn. Motiv. v.13, p. 200-221.

Fanselow, M.S., (1986). Associative vs topographical accounts of the immediate shock-freezing deficit in rats: Implication for the response selection rules governing species-specific defensive reactions. Learn. Motiv., v.17, p. 16-39. 
Fanselow, M.S. e Helmstetter, F.J. (1988). Conditional analgesia, defensive freezing, and benzodiazepines. Behav. Neurosci., v.102 n.2, p. 233-243.

Fanselow, M.S. (1990).Factors governing one-trial contextual conditioning. Animal Learning and Behavior, v.18, p. 264-270.

Fanselow, M.S. (2000). Contextual fear, gestalt memories, and the hipoccampus. Behav. Brain Res., v. 110, p.73-81.

Farone, S. V.; Biederman, J. (1998). Neurobiology of attention-deficit hyperactivity disorder. Biological Psychiatry, v. 44, n. 10, p. 951-958.

Fendt, M. e Fanselow, M.S. (1999). The neuroanatomical and neurochemical basis of conditioned fear. Neuroscience Biobehav. Rev.,23, p. 743-760.

Fernandes, C.; File, S.E. (1996). The influence of open arm ledges and maze experience in the elevated plus-maze. Pharmacology, Biochemistry and Behavior, v. 54 , p. $31-40$.

File, S.E. (1992). Behavioural detection of anxiolytic action. Em: Elliot, J.M.; Heal, D.J. ; Marsden, C.A. (Orgs), Experimenta. Approaches to anxiety and depression. John Wiley e Sons Ltd, Chichester, p.25-44.

File, S.E. (1993). The interplay of learning and anxiety in the elevated plus maze. Behavioural Brain Research, v. 58, p. 199-202.

Finley, J.C.; Katz, D.M. (1992) The central organization of carotid body afferent projections to the brainstem of the rat. Brain Research , v.572, p. 108-116.

Flores, C.; Stewart, J.; Salmaso, N.; Zhang, Y.; Boksa, P. (2002). Astrocytic basic fibroblast growth factor expression in dopaminergic regions after perinatal anoxia. Biological Psychiatry, v. 52, n. 4, p. 362-370.

Gallagher, M.; Burwell, R.; Burchinal, M. (1993). Severity of spatial learning impairment in aging: development of a learning index for performance in the Morris water maze. Behavioral Neuroscience, v. 107, p. 618-626.

Gallagher, M.; Nicolle, M.M. (1993). Animals models of normal aging: relationship between cognitive decline and markers in hippocampal circuitry. Behavioural Brain Research, v. 57, p. 155-162. 
Ganong, W. F. (2006) Fisiologia Médica. 19. ed. Rio de Janeiro: McGrall-Hill Interamericana do Brasil, p.639.

Gargaglioni, L. H.; Bícego, K. C.; Nucci, T. B.; Branco, L. G. (2006). Serotoninergic receptors in the anteroventral preoptic region modulate the hypoxic ventilatory response. Respiratory Physiology \& Neurobiology, v. 153, n. 1, p. 1-13.

Geller, I. e Seifter, J. (1960). The effects of meprobamate, barbiturate, amphetamine and promazine on experimentally induced conflict in the rat. Psychopharmacology, p.1482-1492.

Genest, S. E.; Balon, N.; Laforest, S.; Drolet, G.; Kinkead, R. (2007). Neonatal maternal separation and enhancement of the hypoxic ventilatory response in rat: the role of GABAergic modulation within the paraventricular nucleus of the hypothalamus. Journal of Physiology, v. 583, p. 299-314.

Gershan, W. M.; Forster, H. V.; Lowry, T. F.; Korducki, M. J.; Forster, L.; Forster, M. A.; Ohtake, P. J.; Aaron, E. A.; Garber, A. K. (1994).Effect of metabolic rate on ventilatory roll-off during hypoxia. Journal of Applied Physiology, v. 76, n. 6, p. 2310-2314.

Gewirtz, J.C.; Mcnish, K.A. e Davis, M. (2000). Is the hipocampus necessary for contextual fear conditioning? Behav. Brain Res., v.10, p. 83-95.

Gilby, K. L.; Armstrong, J. N.; Currie, R. W.; Robertson, H. A. (1997). The effects of hypoxiaischemia on expression of c-Fos, c-Jun and Hsp70 in the young rat hippocampus. Molecular Brain Research, v. 48, p. 87-96.

Globus, M. Y.; Busto, R.; Dietrich, W. D.; Martinez, E.; Valdes, I.; Ginsberg, M. D. (1988). Effect of ischemia on the in vivo release of striatal dopamine, glutamate, and gamma-aminobutyric acid studied by intracerebral microdialysis. Journal of Neurochemistry, v. 51, n. 5, p. 1455-1464.

Gluckman, P. D.; Pinal, C. S.; Gunn A. J. (2001). Hypoxic-ischemic brain injury in the newborn: pathophysiology and potential strategies for intervention. Seminars in Neonatology, v. 6, n. 2, p. 109-120.

Gourine, A. V.; Llaudete E.; Dale, N.; Spyer, K. M.(2005).Release of ATP in the ventral medulla during hypoxia in rats: role in hypoxic ventilatory response. Journal of Neuroscience, v. 25, n. 5, p. 1211-1218. 
Gozal, D.; Gozal, E.; Simakajornboom, N. (2000a). Signaling pathways of the acute hypoxic ventilatory response in the nucleus tractus solitarius. Respiratory Physiology, v. 121, p. 209-221.

Gozal, D.; Simakajornboom, N.; Czapla, M.A.; Xue, Y.D.; Gozal, E.; Vlasic, V.; Lasky, J.A.; Liu, J.Y. (2000b). Brainstem activation os platelet growth factor-beta receptor modulates the late phase of the hypoxic ventilatory response. Journal of Neurochemistry, v. 74, p. 310-319.

Graeff, F.G.; Silveira, M.S.L.; Nogueira, R.L.; Audi, E.A.; De Oliveira, R.M.W. (1993). Role of the amygdale and periaqueductal gray in anxyiety and panic. Behavioural Brain Research, v. 58, p. 123-31.

Graeff, F.G. (1999). Ansiedade. In Graeff, F.G.; Brandão, M.L. Neurobiologia das doenças mentais. 5. ed. São Paulo: Lemos Editorial. p. 144.

Graeff, F.G. e Brandão, M.L. (1999). Neurobiologia das doenças mentais.5. Edição. São Paulo, Lemos Editorial e Gráficos Ltda.

Graeff, F.G. e Guimarães, F.S. (1999). Fundamentos de Psicofarmacologia. Ed. Atheneu.

Gray, J.A. (1982). The neuropsychology of anxiety. New York, Oxford University Press.

Gray, J.A. (1987). The psychology of fear and stress. Cambridge, Cambridge University Press.

Gray, J.A. e McNaughton, N. (2000). The neuropsychology of anxiety. 2. Edition, New York, Oxford University Press.

Gunn, A. J.; Dragunow, M.; Faull, R. L.; Gluckman, P. D. (1990). Effects of hypoxia-ischemia and seizures on neuronal and glial-like $c$-fos protein levels in the infant rat. Brain Research, v. 531, n. 1-2, p. 105-116.

Gunn, A. J.; Bennet, L. (2008).Timing of injury in the fetus and neonate. Current Opinion in Obstetrics and Gynecology, v. 20, n. 2, p. 175-181.

Hall, J. E; Guyton, A. C. (2002).Tratado de Fisiologia Médica. 10. ed. Rio de Janeiro: Guanabara Koogan.

Handley, S. L. e Mithani, S. (1984). Effects of alpha adrenoceptor agonist and antagonist in a maze - exploration mode of "fear" - motivated behaviour naunyn Schimiedeberg's Archives of Pharmacology, v. 327, p. 1-5. 
Handley, S.L.; Mcblane, J.W. (1993). 5HT drugs in animal models of anxiety. Psychopharmacology, v. 112, p. 13-20.

Haji A.; Takeda, R.; Okazaki, M. (2000).Neuropharmacology of control of respiratory rhythm and pattern in mature mammals. Pharmacology\&Therapeutics, v. 86, n. 3, p. 277-304.

Hedner, T.; Lundborg, P. (1980). Serotonin metabolism in neonatal rat brain during asphyxia and recovery. Acta Physiologica Scandinavian, v. 109, p. 163-168.

Hehre, D. A.; Devia, C. J.; Bancalari, E.; Suguihara, C. (2008). Brainstem amino acidneurotransmitters and ventilatory response to hypoxia in piglets. Pediatric Research, v. 63, n. 1, p. 46-50.

Herlenius, E.; Lagercrantz, H. (2001). Neurotransmitters and neuromodulators during early human development. Early Human Development, v. 65, p. 21-37.

Herschkowitz, M.; Grimm, V. E.; Speiser, Z. (1983). The effects of postnatal anoxia on behaviour and on the muscarinic and beta-adrenergic receptors in the hippocampus of the developing rat. Brain Research, v. 283, n. 2-3, p. 147-155.

Hoffer, M. A. (1970). Cardiac and respiratory function during sudden immobility in wild rodents. Psychonom Med., p.633-647.

Holmes, A.; Rodgers, R.J. (1999). Influence of spatial and temporal manipulations on the anxiolytic efficacy of chlordiazepoxide in mice previously exposed to the elevated plus-maze. Neuroscience and Biobehavioral Reviews, v. 23, p. 971-80.

Hu, S.; Peterson, P. K.; Chao, C. (1997) Cytokine-mediated neuronal apoptosis. Neurochem Int, v. 30, n. 4-5, p. 427-431.

luvone, L.; Geloso, M. C.; Dell'Anna, M. E. (1996). Changes in open field behavior, spatial memory, and hippocampal parvalbumin immunoreactivity following enrichment in rats exposed to neonatal anoxia. Experimental Neurology, v. 139, n. 1, p. 25-33.

Jayalakshmi K.; Singh S. B.; Kalpana B.; Sairam M. ; Muthuraju S.; Ilavazhagan G. (2007). N-acetyl cysteine supplementation prevents impairment of spatial working memory functions in rats following exposure to hypobaric hypoxia. Physiology e behavior, v. $92, n \cdot 4$, p. $643-650$

Johnston, M.V.; Nakajima, W.; Hagberg, H. (2002). Mechanisms of Hypoxic Neurodegeneration in the Developing Brain. The Neuroscientist, v. 8, p. 212-220. 
Juárez, I.; Silva-Gómes, A. B.; Peralta, F.; Flores, G. (2003). Anoxia at birth induced hyperresponsiveness to amphetamine and stress in postpubertal rats. Brain Research, v. 992, n. 2, p. 281-287.

Kesner, R.P. (1986). Neurobiological Views of Memory. In Joe L. Marinez Jr. and Raymond P. Kesner (Eds.), Learning and Memory. A Biological View. San Diego: Academic Press, p. 399-438.

Kheirandish, L.; Gozal, D.; Pequignot, J.; Pequignot, J.; Row, B. W. (2005). Intermittent hypoxia during development induces long-term alterations in spatial working memory, monoamines, and dendritic branching in rat frontal córtex. Pediatric research, v. 58, p. 594-599.

Lalley, P.M.; Bischoff, A.M.; Richter, D.W. (1994).Serotonin 1-a receptor activation suppresses respiratory apneusis in the cat. Neuroscience Letters, v. 172, p. 59-62.

Lauder, J. M.; Moiseiwitsch, J.; Liu, J.; Wilkie, M. B. (1994). Serotonin in development and pathophysiology. In: Lou, H. C.; Greisen G.; Falck-Larsen, J. (Ed.). Brain Lesions in the Newborn. Munksgaard: Alfred Benzon Symposium,. v. 37 , p. 60-72.

Laviola, G.; Adriani, W.; Rea, M.; Aloe, L.; Alleva, E. (2004). Social withdrawal, neophobia, and stereotyped behavior in developing rats exposed to neonatal asphyxia. Psychopharmacology, v. 175, n. 2, p. 196-205, 2004.

LeDoux, J. E.; Ruggiero, D. A.; Forest, R.; Stornetta, R.; Reis, D. J. (1987). Topographic organization of convergent projections to the thalamus from the inferior colliculus and spinal ord in the rat. J. Comp. Neurol., v. 264, p. 123-146

LeDoux, J. E.; Farb, C. e Ruggiero, D.A. (1990). Topographic organization of neurons in the acoustic thalamus that project to the amygdala. J. Neurosci., v. 10, p. 1043-1054.

LeDoux, J.E.; Cicchetti, P.; Xagoraris, A. e Romanski, L.M. (1990b). The lateral amygdaloid nucleus: Sensory interface of the amygdala in fear conditioning. J. Neurosci., v. 10, p. 1062-1069.

Levitzky, M. G. Fisiologia Pulmonar. 6. ed. São Paulo: Manole, 2004. p. 277.

Lister, R.G. (1987) The use of a plus-maze to anxiety in the mouse. Psychopaharmacology, v. 93, p 180-185.

Liu, Q.; Lowry, T. F.; Wong-riley, M. T. (2006).Postnatal changes in ventilation during normoxia and acute hypoxia in the rat: implication for a sensitive period. Journal of Physiology, v. 577, p. 957-970. 
Loidl, C.F.; Gavilanes, A.W.D.; Van Dijk, E.H.J.; Vreuls, W.; Blokland, A.; Vles, J.S.H.; Steinbusch, H.W.M.; Blanco, C.E. (2000). Effects of hypothermia and gender on survival and behavior after perinatal asphyxia in rats. Physiology \& Behavior, v. 68, p. 263-269.

Lou, H. C; Lassen, N.A. (1997) Low cerebral bood flor in hypotensive perinatal distress. Acta Neurol Scand v. 56, p. 343-352.

Machado, A. B. M. (2004).Neuroanatomia Funcional. 2. ed. São Paulo: Atheneu, p. 363.

Mcguire, M.; Zhang, Y.; White, D. P.; Ling, L. (2003). Chronic intermittent hypoxia enhances ventilatory long-term facilitation in awake rats. Journal of Applied Physiology, v. 95, n. 4, p. 1499 - 1508.

Madi, J. M. (2003) Meconium aspiration síndrome: obstetric and perineal outcome análisis. Rev. Bras. Ginecol Obstret, v. 25, n.2, p. 123-128.

Majeed, R.; Memon, Y.; Majeed, F.; Shaikh, N. P.; Rajar, U. D. (2007). Risk factors of birth asphyxia. Journal of Ayub Medical College, Abbottabad, v. 19, n. 3, p. 6771.

Manhães de Castro, R.; Barreto Medeiros, J. M.; Mendes da Silva, C.; Ferreira, L. M.; Guedes, R. C.; Cabral Filho, J. E.; Costa, J. A. (2001). Reduction of intraspecific agression in adult rats by neonatal treatment with a selective serotonin reuptake inhibitor. Brazilian Journal of Medical and Biological Research, v. 34, n. 1, p. 121-124.

Maren, S.; Aharonov, G. e Fanselow, M. S. (1997). Neurotoxic lesions of the dorsal hippocampus and Pavlovian fear conditioning in rats. Behav. Brain Res., v. 88, p. 261-274.

Maren, S. e Holt, W. (2000). The hippocampus and contextual memory trieval In Pavlovian conditioning. Behav. Brain Res., v. 110, p. 97-108.

Markowaska, A.L.; Olton, D.S.; Murray, E.A. e Gaffan, D. (1989). A comparative analysis of the role of fornix and cingulate cortex in memory: rats. Experimental Brain Research, v. 74, p.187-201.

Maxová, H.; Vízek, M. (2001). Biphasic ventilatory response to hypoxia in unanesthetized rats. Physiological Resesarch, v. 50, n. 1, p. 91-96.

McMahon, M. J.; Kuller, J. A.; Jankowitz, J. (1996). Assessnent of the post-term pregnancy. Am Fam Phisician, v. 54, n. 2, p. 631-636. 
Meck, W.H.; Church, R.M. e Olton, D.S. (1984). Hippocampus, Time, and Memory. Behavioral Neuroscience, v.98, p. 3-22.

Meck, W.H.; Church, R.M.; Wenk, G.L. e Olton, D.S. (1987). Nucleus basalis magnocellularis and medial septal area lesions differentially impair temporal memory. Journal Neuroscience, v. 404, p. 3505-3511.

Mikati, M. A.; Zeinieh, M. P.; Kurbi, R. M.; Harb, S. A. ; El Hokayem, J. A.; Shamseddine, A.; Obeid, M.; Bitar, F. F.; El Sabban, M. (2005). Long-term effects of acute and of chronic hypoxia on behavior and on hippocampal histology in the developing brain. Developmental Brain Research, v. 157, n. 1, p. 98-102.

Modalen, A. Q.; Quiding, H.; Frey, J.; Lindah, S. (2006). A novel molecule with peripheral opioid properties: the effects on hypercarbic and hypoxic ventilation at steady-state compared with morphine and placebo. Anesthesia \& Analgesia, v. 102, n. 1, p. 104-109.

Morgane, P. J.; Austin-Lafrance, R.; Bronzino, J.; Tonkiss, J.; Díaz-Cintra, S.; Cintra, L.; Kemper, T.; Galler, J. R. (1993). Prenatal malnutrition and development of the brain. Neuroscience Biobehavioral Reviews, v. 17, n. 1, p. 91-128.

Morris, R.G.M. (1981), Spatial localization does not require the presence of local cues. Learning and Motivation, v. 12, p. 239-60, 1981.

Morris, R.G.M.; Garrud, P.; Rawilin, J.N.; O’Keefe, (1982). J. Place navigation impaired in rats with hippocampal lesions. Nature, v. 297, p. 681-683.

Morris, R.G.M. (1983) An attempt to dissociate "spatial-mapping" and "workingmemory" theories of hippocampal function. In: Seifert, W. Neurobiology of the hippocampus. London: Academic Press, p. 405-432.

Morris, R. G.; Anderson, E.; Lynch G. S.; Baudry, M. (1986). Selective impairment of learning and blockade of-term potentiation by an $\mathrm{N}$-methyl-D-aspartate receptor agonist, AP5. Nature, v. 319, p. 774-776.

Moser, M.B.; Moser, E.I.; Forrest,E.; Andersen, P.; Morris, R.G. (1995), Spatial learning with a minislab in the dorsal hippocampus. Proceedings of the National Academy of Sciences of the United States of America, v. 92, p. 96709697.

Moser, M. B.; Moser, E. (1998), Distributed Encoding and Retrieval of Spatial Memory in the Hippocampus . The Journal of Neuroscience, v.18, p. 7535-7542 
Mulkey, D. K.; Stornetta, R. L.; Weston, M. C.; Simmons, J. R.; Parker, A.; Bayliss, D. A.; Guyenet, P. G. (2004). Respiratory control by ventral surface chemoreceptor neurons in rats. Nature Neuroscience, v. 7, n. 12, p. 1360-1369.

Murray, E.A., Davidson, M., Gaffan, D., Olton, D.S. \& Suomi, S., (1989). Effects of fornix transection and cingulate cortical ablation on spatial memory in rhesus monkeys. Experimental Brain Research, v. 74, p.173-186.

Nakajima, W.; Ishida, A.; Takada, G. (1996). Effect of anoxia on striatal monoamine metabolism in immature rat brain compared with that of hypoxia: an in vivo microdialysis study. Brain Research, v. 740, p. 316-322.

Nakajima, W.; Ishida, A.; Takada, G. (1999). Anoxic and hypoxic immature rat model for measurement of monoamine using in vivo microdialysis. Brain Research Protocols, v. 3, p. 252-256.

Nakazawa, K.; Mchugh, T. J.; Wilson, M. A.; Tonegawa, S. (2004). NMDA receptors, place cells and hippocampal spatial memory. Nature Reviews Neuroscience, v. 5, n. 5, p. 361-372.

Naqui, S. Z.; Harris, B. S.; Thomaidou, D.; Parnavelas, J. G. (1999). The noradrenergic system influences the fate of Cajal-Retzius cells in the developing cerebral cortex. Developmental Brain Research, v. 113, n. 1-2, p. 75-82.

Nattie, E. (2001). Multiple sites for central chemoreception: their roles in response sensitivity and in sleep and wakefulness. Respiratory Physiology, v. 122, n. 2-3, p. 223-235.

Nutt, D.J. (1990). The pharmacology of human anxiety. Pharmacol. Ther. V.47, p.233-266.

Nyakas, C.; Buwalda, B.; Luiten, P.G.M. (1996). Hypoxia and Brain Development. Progress in Neurobiology, v. 49, p. 1-51.

Ohtake, P.J.; Torres, J.E.; Gozal, Y.M.; Graff, G.R., Gozal D. (1998). NMDA receptors mediate peripheral chemoreceptor afferent input in the conscious rat. Journal of Applied Physiology, v. 84, p. 853-861.

O’Keefe , J.; Nadel, L. (1978). The hippocampus as a cognitive map. Oxford: Oxford University Press.

Oliveira-Alonso G. S.; Silveira V. C. (2007). Lesões encefálicas infantis adquiridas. In: Fernandes, A. C.; Ramos, A. C. R.; Casalis, M. E. P.; Hebert, S. K. (Ed). AACD Medicina e Reabilitação: princípios e prática. São Paulo: Artes Médicas,. p. 161172. 
Olton, D.S.; Samuelson, R.J. (1976). Remembrance of places passed: Spatial memory in rats. Journal of Experimental Psychology: Animal Behavior Processes, v. 2 , p. $97-116$.

Olton, D.S. (1979). Mazes, maps and memory. American Psychologist, v. 34, p. 583-96.

Olton, D.S., Becker, J.T. \& Handelmann, G.E., (1979). Hippocampus, space and memory. Behav. Brain Sci., v.2, p.313-322.

Olton, D.S., (1986). Hippocampal Function and Memory for Temporal Context. In R.L. Isaacson and K.A. Pribran (Eds.), The Hippocampus. Vol 4, New York: Plenum Pess, p.281-298.

Olton, D.S., (1990). Mnemonic Functions of the Hippocampus: Past, Present and Future. In Larry R. Squire and Elke Lindenlaub (Eds.), The Biology of Memory: Symposium Bernried, Germany October 15th-19th, 1989. Stuttgart: Schattauer Verlag, p.427-443.

Oorschot, D.E.; Black, M.J.; Rangi, F.; Scarr, E. (2000). Is Fos Protein Expressed by Dying Striatal Neurons after Immature Hypoxic-Ischemic Brain Injury? Experimental Neurology, v. 161, p. 227-233.

Pellow, S.; Chopin, P.; Briley, M. (1985). Validation of open-closed arm entries in an elevated plus-maze as a measure of anxiety in the rat. Journal of Neuroscience Methods, v. 14, p. 149-67.

Pellow S.; File, S.E. , (1986) Anxiolytic and anxiogenic drug effects on exploratory activity in an elevated plus-maze: a novel test of anxiety in the rat. Pharmacology, Biochemistry and Behavior, v.24, p. 525-29.

Pinheiro, S.H.; Zangrossi-Jr, H.; Del-Bem, C.M.; Graeff, F.G. (2007). Elevated mazes as animal models of anxiety: effects of serotonergic agents. Anais da Academia Brasileira de Ciências, v. 79, p. 71-85.

Powell, F.L.; Milsom, W.K.; Mitchell, G.S. (1998). Time domains of the hypoxic ventilatory response. Respiratory Physiology, v. 112, p. 123-134.

Putnam, R. W.; Filosa, J. A.; Rituccil, N. A. 2004. Cellular mechanisms involved in $\mathrm{CO}(2)$ and acid signaling in chemosensitive neurons. American Journal of Physiology and Cellular Physiology, v. 287, n. 6, p. 1493-1526.

Raffaele, K.C. e Olton, D.S., (1988). Hippocampal and amygdaloid involvment in working memory for nonspatial stimuli. Behavioral Neuroscience, v. 102, p.349355. 
Raskin, L. A.; Shaywitz, S. E.; Shaywitz, B. A.; Anderson, G. M.; Cohen, D. J. (1984). Neurochemical correlates of attention deficit disorder. Pediatric Clinics of North America, v.31, p. 387-396.

Redish, A.D. (2001). The hippocampal debate: are we asking the right questions? Behav. Brain Res., v. 127, p. 81-98.

Rice J.E, Vannucci R.C e Brierley JB. (1981) The influence of immaturity on hypoxic-ischemia brain damage in the rat. Ann Neurol v. 9 p.131-141.

Robertson, C. M.; Finer, N. N. (1983). Long-term follow-up of term neonates with perinatal asphyxia. Clonics in perinatology, v. 20, p. 483-500.

Richerson, G. B. (2004). Serotonergic neurons as carbon dioxide sensors that maintain pH homeostasis. Nature Reviews Neuroscience, v. 5, n. 6, p. 449-461.

Rodgers, R. J; Johnson, N. J. (1985). Factor analysis of spatiotemporal and ethological measures in the murine elevated plus-maze test of anxiety. Pharmacology, biochemistry, and behavior, v. 52, p. 297-303

Rodgers, R.J.; Cole, J.C. (1994). The elevated plus-maze: pharmacology, methodology and ethology. In: Cooper, S.J.; Hendrie, C.A. Ethology and Psychopharmacology. Chichester: Wiley, p. 9-44.

Rogalska, J.; Caputa, M.; Wentowska, K.; Nowakowska, A. (2004). Stress-induced behaviour in juvenile rats: effect of neonatal asphyxia, body temperature and chelation of iron. Behavioural Brain Research, v. 154, p. 321-329.

Rogalska, J.; Caputa, M.; Wentowska, K.; Nowakowska, A. (2006). Stress-induced behaviour in adult and old rats: effects of neonatal asphyxia, body temperature and chelation of iron. Journal of Physiology and Pharmacology, v. 57, n. 8, p. 17-34.

Row, B. W.; Goldbart, A.; Gozal, E.; Gozal, D. (2002). Spatial pre-training attenuates hippocampal impairments in rats exposed to intermittent hipóxia. Neuroscience Letters, v. 339, p. 67-71

Rudy, J.W. e Sutherland, R.J. (1989). The hippocampal formation is necessary for rats to learn and remember configural discriminations. Behavioural Brain Research, v. 34, p. 97-109 
Rudy, J.W.; Huff, N.C.; Matus-Amat, P. (2004).Understanding contextual fear conditioning: insights from a two-process model. Neuroscience and Biobehavioral Reviews, v. 28, p.675-685.

Sandager-nielsen, K.; Andersen, M. B.; Sager, T. N.; Wwege, T.; Scheel-Kruger, J. (2004). Effects of postnatal anoxia on striatal dopamine metabolism and prepulse inhibition in rats. Pharmacology, Biochemistry and Behavior, v. 77, p. 767-774.

Santos, A.M.G. (1999). Aprendizagem e memória no labirinto aquático de Morris. In: Xavier, G.F. Técnicas para o estudo do sistema nervoso. São Paulo: Plêiade, p. 131-154.

Scoville, W.B. e Milner, B. (1957). Loss of recent memory after bilateral hippocampal lesion.J. Neurol. Neurosurg. Psychiatry, v. 20, p. 11-21

Semenza, G. L. (2000). Surviving ischemia: adaptive responses mediated by hypoxia-inducible factor 1. Journal of Clinical Investigation, v. 106, n. 7, p. 809-812.

Silverthorn, , D. U. Fisiologia Respiratória. In: Silverthorn, D. U. FisiologiaHumana: uma abordagem integrada. 2. ed. São Paulo: Manole, 2003, p. 497-535.

Simakajornboon, , N.; Kuptanonb N, T. (2005). Maturational changes in neuromodulation of central pathways underlying hypoxic ventilatory response. Respiratory Physiology \& Neurobiology, v. 30, p. 1-14

Simonova, Z.; Sterbova, K.; Brozek ,G.; Komarek, V.; Sykova, E. (2003), Postnatal hypobaric hypoxia in rats impairs water maze learning and the morphology of neurones and macroglia in córtex and hippocampus. Behav. Brain Res, v. 141, p. 195-205.

Speiser, Z.; Kotzyn, A. D.; Teplitzy I.; Gitter, S. (1983). Hyperactivity in rats following postnatal anoxia. Behav. Brain, Res. v. 7, p. 379-382

Speiser, Z.; Katzir, O.; Rehavi, M.; Zabarski, T. ; Cohen, S. (1998). Sparing by rasagiline (TVP-1012) of cholinergic functions and behavior in the postnatal anoxia rat. Pharmacology Biochemistry and Behavior, v. 60, n. 2, p. 387-393.

Strata, F.; Coq, J. O.; Byl, N.; Merzenich, M. M. (2004). Effects of sensorimotor restriction and anoxia on gait and motor cortex organization: implications for a rodent model of cerebral palsy. Neuroscience, v. 129, n. 1, p. 141-156.

Suguihara, C.; Lessa, A. C. (2005). Strategies to minimize lung injury in extremely low birth weight nfants. Jornal de Pediatria, Rio de Janeiro, v. 81, p. 69-78. Suppl. 1. 
Sundstrom, E.; Kolare, S.; Souverbie, F.; Samuelsson, E. B.; Pschera, H.; Lunell, N. O.; Seiger, A. (1993). Neurochemical differentiation of human bulbospinal monoaminergic neurons during the first trimester. Developmental Brain Research, v. 75, n. 1, p. $1-12$.

Sutherland, R.J. e McDonald, R.J. (1990) Hippocampus, amygdala, and memory deficits in rats. Behav. Brain Res., v.37, p. 57-79.

Takada, S. H.; Allemandi, W.; Ito,P.H.; Takase, L.F; Nogueira, M.I. (será resubmetido). Adequação e validação de modelo de anóxia neonatal em ratos pela oximetria de pulso imunorreatividade à proteína Fos. Journal Neuroscience Methods.

Takagi, N.; Logan, R.; Teves, L.; Wallace, M.C.; Gurd, J. W. (2000). Altered interaction between PSD-95 and NMDA receptor following transient global ischemia. J. Neurosci. v. 74, p. 169-178.

Tang, A. C.; Nakazawa, M. (2005). Neonatal novelty exposure ameliorates anoxiainduced hyperactivity in the open field. Behavioural Brain Research, v. 163, n. 1, p. 1-9.

Ten, V. S.; Bradley-Moore, M.; Gingrich, J. A.; Stark, J.; Pinsky, D. J. (2003). Brain injury and neurofunctional deficit in neonatal mice with hypoxic-ischemic encephalopathy. Behavioral Brain Research, v. 145, n. 1-2, p. 209-219.

Teichtahl, H.; Wang, D.; Cunnington, D.; Quinnell, T.; Tran, H.; Kronborg, I.; Drummer, O. H. (2005). Ventilatory responses to hypoxia and hypercapnia in stable methadone maintenance treatment patients. Chest, v. 128, n. 3, p. 13391347.

Treit, D. (1985). Animal models for the study of anti-anxiety agents: a review. Neurosci. Biobehav. Rev.,v. 9, p,203-222.

Treit, D.; Menard, J.; Royan, C. (1993).Anxiogenic stimuli in the elevated plusmaze. Pharmacology, Biochemistry and Behavior, v. 44, p. 463-69.

Tryba, A. K.; Peiia, F.; Ramirez, J. M.(2006). Gasping activity in vitro: a rhythm dependent on 5- HT2A receptors.Journal of Neuroscience, v. 26, n. 10, p. 26232634.

Vannucci, R.C. (1997). Hypoxia-ischemia: Clinical aspects. In: Fanaroff, A. A.; Martin R. J. (Ed.) Neonatal perinatal medicine. 4. ed. Philadelphia: MosbyYearbook. p. 877-891. 
Vannucci, R.C.; Connor, J.R.; Mauger, D.T.; Palmer, C.; Smith, M.B.; Towfighi, J.; Vannucci, S.J. (1999). Journal of Neuroscience Research, v. 55, p. 155-163.

Veronesi, A.; Valanzano, A.; Cirulli, F.; Alleva, E.; Calamandrei, G. (2004). Acute global anoxia during C-section birth affects dopamine-mediated behavioural responses and reactivity to stress. Behavioural Brain Research, v. 154, p. 155-164.

Vexler, Z.S.; Ferriero, D.M. (2001). Molecular and biochemical mechanisms of perinatal brain injury. Seminars in Neonatology, v.6, p. 99-108.

Vizek, M.; Picket, C.K.; Weil, J.V. (1987). Biphasic ventilatory response of adult cats to sustained hypoxia has central origin. Jornal of Applied Physiology, v. 63, p. 1658-1664.

Vlasic, V.; Simakajornboon, N.; Gozal E.; Gozal, D. (2001). PDGF-beta receptor expression in the dorsocaudal brainstem parallels hypoxic ventilatory depression in the developing rat. Pediatric Research, v. 50, n. 2, p. 236-241.

Vogel, J.R.; Beer, B. e Clody, D.E. (1971). A simple and reliable conflit of procedure for testing anti-anxiety agents. Psychopharmacology, v. 21, p. 1-7.

Volpe, J.J. (1992). Perinatal hypoxic-ischemic brain injury: overview. In: Fukuyama, Y.; Suzuki, Y.; Kamamoshita, S; Casaer, P. (Ed.). Fetal and Perinatal Neurology. Tokyo: Joint Convention of the 5th International Child Neurology and the 3rd Asian and Oceanian Congress of Child Neurology. p. 232-252.

Wainwright, M.S.; Craft, J.M.; Griffin, S.T.; Marks, A.; Pineda, J.; Padgett, K.R.; Eldik, V. (2004). Increased Susceptibility of S100B Transgenic Mice to Perinatal Hypoxia-Ischemia. Annals of Neurology, v. 56, p. 61-67.

WalKer, J.A.e Olton, D.S., (1984). Fímbria-fórnix lesions impair spatial working memory but not cognitive mapping. Behavioral Neuroscience, 98, pp. 226-242.

Wall, P. M.; Messier, C. (2001). Methodological and conceptual issues in the use of elevated plus-maze as a psychological measurement instrument of animal anxietylike behavior. Neuroscience and Biobehavioral Reviews, v. 25, p. 275-86

Whishaw, I. Q., e Mittleman, G. (1986). Visits to starts, routes and places by rats (Rattus norvegicus) in swimming pool navigation tasks. Journal of Comparative Physiology, v.100, p. 422-431.

Who Workd Health Organization (2003). The World Health Report. 
Wilson-Costello, D.; Friedman, H.; Minich, N. (2005). Improved survival rates with increased neurodevelopmental disability for extremely low birth weight infants in the 1990s, Pediatrics, v. 115, p. 997-1003.

Whitney, G. M.; Ohtake, P. J.; Simakajornboom, N.; Xue, Y. D.; Gozal, D. (2000). AMPA glutamate receptors and respiratory control in the developing rat: anatomic and pharmacological aspects. American Journal of Physiology - Regulatory, Integrative and Comparative Pysiology, v. 278, n. 2, p. 520-528.

Xavier, G.F. (1985). Atividade exploratória em ratos com lesões no hipocampo e secção do fórnix. Implicações para as teorias sobre a função hipocampal. $288 \mathrm{f}$. Tese (Doutorado em Psicobiologia) - Escola Paulista de Medicina, São Paulo.

Xavier, G.F. (1989). Memória espacial no rato. In: Ades, C. Etologia de animais e de homens. São Paulo: Edicon, p. 61-74.

Xavier, G.F. (1993). A modularidade da memória e o sistema nervoso. Psicologia USP. São Paulo, v. 4, p. 61-115.

Xavier, G.F.; Oliveira-Filho, F.J.; Santos, A.M. (1999). Dentate gyrus-selective colchicine lesion and disruption of performance in spatial tasks: difficulties in "place strategy" because of a lack of flexibility in the use of environmental cues? Hippocampus, v. 9, p. 668-681.

Xia, Y.; Haddad, G.G. (1991). Ontogeny and distribution of opioid receptors in the rat brainstem. . Brain Research, v. 549, p. 181-193.

Yamamoto, H.; Kato, T. (1986). The effect of neonatal anoxia on brain cholecystokinin-8-like immunoreactivity and monoamine levels of mature rats. Brain Research, v. 391, n. 2, 285-288.

Zhao, H.; Zhang, Z.; Wang, D. (1996). Asphyxia of the newborn delivered by elective cesarean section and gastroesophageal reflex and aspiration. Zhonghua Fu Chan Ke Za Zhi, v. 31, n.2, p. 718-720.

Zubrick, S. R.; Macartney H.; Stanley F.J. (1988). Hidden handicap in school age children who received neonatal intensive care. Dev. Med Chile Neurol, v. 30, p. 145-152. 



